\title{
Funktion des Wind-Proteins in Drosophila melanogaster bei Faltung und/ oder Transport des sekretorischen Proteins Pipe
}

\author{
Dissertation \\ zur Erlangung des Doktorgrades \\ der Mathematisch-Naturwissenschaftlichen Fakultäten \\ der Georg-August-Universität zu Göttingen
}

\author{
vorgelegt von \\ Kathrin Barnewitz \\ aus Göttingen
}

Mai 2004 
D 7

Referent: $\quad$ Prof. Dr. H.D. Söling

Korreferent: Prof. Dr. R. Hardeland

Tag der mündlichen Prüfung: 01.07.2004 
Die vorliegende Arbeit wurde in der Zeit von Februar 2002 bis Mai 2004 im Max-PlanckInstitut für Biophysikalische Chemie, Abteilung Neurobiologie, unter der Anleitung von Herrn Prof. Dr. H.D. Söling durchgeführt.

Teile dieser Arbeit wurden veröffentlicht:

Ma, Q., Barnewitz, K., Sheldrick, G.M., Söling, H.D., Uson, I. und Ferrari, D.M. (2003) Crystal structure and functional analysis of drosophila Wind - a protein-disulfide isomeraserelated protein. J. Biol. Chem. 278(45):44600-7.

bzw. zur Veröffentlichung eingereicht:

Barnewitz, K., Guo, C., Sevvana, M., Ma, Q., Sheldrick, G.M., Söling, H.D. und Ferrari D.M. (2004) Determination of a substrat-binding site in the protein disulfide isomeraserelated chaperone Wind. 


\section{Danksagung}

Ich danke Herrn Prof. Dr. Hans-Dieter Söling für die Vergabe dieser Doktorarbeit, für sein Interesse am Fortgang der Arbeit, für seine Unterstützung und das kritische Lesen des Manuskriptes.

Ich möchte Herrn Prof. Dr. Rüdiger Hardeland, Institut f. Zoologie der Universität Göttingen, für die Übernahme des Co-Referates meiner Doktorarbeit danken.

Grosser Dank gebührt Herrn Prof. Dr. Reinhard Jahn und seinen Mitarbeitern in der Abteilung Neurobiologie am Max-Planck-Institut für biophysikalische Chemie für ein produktives Arbeitsumfeld.

Besonderer Dank gilt Herrn Dr. David M. Ferrari für die Betreuung meiner Arbeit, das Anlernen neuer Techniken, für stete Bereitschaft zu Diskussionen und das Lesen des Manuskriptes.

Ich möchte meinen ehemaligen und derzeitigen Arbeitskollegen in der Söling-Gruppe für ein angenehmes, produktives Arbeitsklima danken: Michael, Maja, Matthias, Chaoshe, Sophie, sowie Quinjun und Madhumati. Besonderer Dank gilt Madhumati für die Erstellung der Strukturbilder.

Ich danke den Herren Dr. Dirk Wenzel und Dr. Ullrich Kuhnt für das Lesen des Manuskriptes.

Ich danke Ira für viele gemeinsame Nachmittage mit interessanten Diskussionen im Mikroskopraum.

Ich danke Dr. M. Takamori, Abteilung Entwicklungsbiologie, Max-Planck-Institut für biophysikalische Chemie, für einige Mikroliter an genomischer Fliegen-DNA.

Ich danke sowohl Gordon Dowe, Abteilung Entwicklungsbiologie, Max-Planck-Institut für biophysikalische Chemie als auch dem Seqlab-Team, Göttingen, für die vielen notwendigen Sequenzierungen im Rahmen dieser Arbeit.

Ein grosses Dankeschön richte ich an die Firma Sysy, Göttingen für einen guten GFPAntikörper.

Ich danke meinen Freunden Kristina, Kirsten, Sandra, Martin S., Martin D. und Matthias für ihre Freundschaft, ihr Interesse und ihre Unterstützung.

Meinen Eltern und Grosseltern danke ich für ihre Unterstützung und die Ermöglichung dieses Studiums. 


\section{$\underline{\text { Inhaltsverzeichnis }}$}

1. Zusammenfassung 1

2. Einleitung 3

2.1. Das Endoplasmatische Retikulum und der Golgi-Apparat 3

2.1.1. Proteinfaltung 3

2.2. $\quad$ Protein Disulfid Isomerasen (PDI) 5

2.2.1. Charakteristika der PDI 5

2.2.2. Redox-Isomerase-Funktion von PDI 6

2.2.3. Mitglieder der PDI-Familie 7

2.3. Funktion von Wind 11

$\begin{array}{lll}\text { 2.4. } & \text { Struktur von Wind } & 13\end{array}$

$\begin{array}{ll}\text { 3. Ziel der Arbeit } & 15\end{array}$

4. Material 16

4.1. Versuchstiere 16

4.2 Chemikalien 16

4.3. Zellkulturreagenzien/-zusätze 16

4.4. Molekularbiologische Kits und Enzyme 16

4.5. Plasmid-Vektoren 17

4.6. Bakterielle Stämme 17

$\begin{array}{lll}\text { 4.7. } & \text { Medium für Bakterienkultur } & 17\end{array}$

$\begin{array}{lll}\text { 4.7.1. } & \text { Herstellung von Bakterienmedium } & 17\end{array}$

4.7.2. Additive für Bakterienmedium 18

$4.8 \quad$ Säuger-Zelllinien $\quad 18$

4.9. Oligonukleotide 18

4.10. Reagenzien für die Proteinanalytik 18

5. Methoden 19

5.1. Immunisieren von Kaninchen 19

$\begin{array}{lll}\text { 5.2. } & 19\end{array}$

5.2.1. Protein-Quantifizierung nach Bradford 21

5.3. Klonierungen 21

5.3.1. $\quad$ cDNA-Klonierung von ERp28 aus Maus F9-Zellen 21

5.3.2. Reamplifikation von $D$. melanogaster Wind-DNA 22

5.3.3. Generierung von Punktmutationen in Wind 23

5.3.4. Amplifikation von Deletionskonstrukten von Wind 26

5.3.4.1. Weitere Konstrukte: Generierung eines Fusionskonstruktes von Wind 27 mit ERp28

5.3.4.2. Generierung eines ssD-Konstruktes von Wind 28

5.3.4.2.1. Annealing oligo-Methode 29

5.3.4.3. Generierung von am N-Terminus von Wind verlängerten Konstrukten 29

5.3.5. Klonierung von Pipe 31

5.3.5.1. Generierung eines Pipe-Myc Konstruktes 33 
5.3.5.2. Generierung eines Konstruktes der löslichen Domäne von Pipe 34 sowie Deletionskonstrukte der löslichen Domäne

5.3.5.3. Generierung von Transmembran-Konstrukten von Pipe 35

5.3.5.4. Mutation im pEGFP-Vektor $\quad 35$

5.4. Untersuchung von DNA durch Agarosegelelektrophorese $\quad 35$

5.5. Aufreinigung von DNA aus Agarosegelen und DNA-Konzentrations- 36

5.6. $\quad$ Restriktionsanalyse, Dephosphorylierung und Ligation 36

$\begin{array}{lll}\text { 5.7. } & \text { Transformation von E. coli } & 37\end{array}$

5.7.1. Herstellung elektrokompetenter E. coli-Zellen 37

5.7.2. Herstellung chemisch kompetenter E. coli-Zellen 38

5.7.3. Transformation durch Elektroporation 38

5.7.4. Transformation durch Hitzeschock 39

5.8. DNA-Präparationen 39

5.8.1. Sequenzierung von DNA 40

5.9. Protein-Gelelektrophorese 40

5.9.1. Denaturierende SDS-Polyacrylamid-Gelelektrophorese nach Laemmli 40

5.10. Anfärben von Proteinen in Polyacrylamid-Gelen 42

5.10.1. Coomassie-brilliant-Blau-Färbung 42

5.11. Western Blot nach Towbin 43

5.11.1. Western Blot auf Nitrocellulose-Membranen 43

5.11.2. Proteinidentifizierung auf Nitrocellulose-Membranen mit Antikörpern 43

5.11.3. Detektion durch Chemilumineszenz 44

5.12. Sterilisation von Material und Lösungen 44

5.13. Zellkultur-Techniken 44

5.13.1. Auftauen von gefrorenen Zellen 44

5.13.2. Kultur von Säugetier-Zellen 44

5.13.3. Transfektion von COS 7-Zellen durch Elektroporation 45

5.14. Immunfluoreszenz 45

5.15. Protein-Protein-Interaktionen 46

5.15.1. Oligomerisierungs-Experimente 46

5.15.1.1. $\quad$ Cross-linking von Wind-WT bzw. Wind-Mutanten mit Disuccinimidyl- 46 suberat (DSS)

\section{Ergebnisse}

6.1. Direkte Interaktion von Wind mit Pipe 48

6.1.1. Deletions-Mutagenese von Wind 48

6.1.2. Identifizierung einer Bindestelle für Pipe in der Thioredoxin-Domäne von 51 Wind

6.1.2.1. Die PDI-Dß-Schleife ist nicht an der Interaktion mit Pipe beteiligt 61

6.1.2.2. Weder der geladene Dimerspalt noch der Raum in ihm ist essentiell an 62 der Interaktion mit Pipe beteiligt

6.1.2.3. Interaktion von Wind mit Pipe findet ohne Beteiligung des flexiblen $\quad 65$

Linkers statt

6.1.2.4. Das CTGC-Motiv in Wind ist nicht an der Pipe-Interaktion beteiligt 65

6.1.2.5. Untersuchung der D-Domäne von Wind bezüglich seiner Bindung an 66

Pipe

6.1.3. Untersuchung der Pipe-Retention 68

6.2. Oligomerisierungsexperimente 69

6.2.1. Oligomerisierung von Wind 69 
$\begin{array}{lll}\text { 6.2.2. } & \text { Oligomerisierung von Pipe }\end{array}$

$\begin{array}{ll}\text { 7. Diskussion } & 73\end{array}$

$\begin{array}{ll}\text { 8. Literaturverzeichnis } & 79\end{array}$

$\begin{array}{lr}\text { 9. Abkürzungsverzeichnis } & 84\end{array}$ 


\section{Zusammenfassung}

Thema meiner Doktorarbeit war die funktionelle Analyse des Wind-Proteins der Fruchtfliege Drosophila melanogaster. Wind ist ein im Endoplasmatischen Retikulum (ER) lokalisiertes, luminales Protein und wird der Familie der Protein-Disulfid-Isomerasen (PDI) zugeordnet. Es ist ein wichtiger Schlüsselfaktor in der dorso-ventralen Entwicklung in $D$. melanogaster. Stein und Mitarbeiter fanden heraus, dass Wind für die korrekte Lokalisation des Proteins Pipe, eines Golgi-Transmembranproteins vom Typ II, notwendig ist (Stein et al., 2000).

Der Arbeitsgruppe Söling gelang es in Zusammenarbeit mit der Abteilung für Strukturchemie der Universität Göttingen das Wind-Protein bei einer Auflösung von 1,9 Å zu kristallisieren (Ma et al., 2003).

Die Ergebnisse zeigten, dass Wind als Homodimer kristallisiert. Das Wind-Monomer setzt sich dabei aus 2 verschiedenen Domänen zusammen: einer N-terminalen ThioredoxinDomäne mit der charakteristischen Abfolge von $\beta$-Faltblättern und $\alpha$-Helices und einer $C$ terminal gelegenen $\alpha$-helikalen D-Domäne. Beide Domänen werden über einen flexiblen Linker von 11 Aminosäuren kovalent miteinander verbunden. Das Dimer wird allein durch die Thioredoxin-Domänen gebildet. Durch die Homodimerisierung entsteht ein tiefer, hydrophiler, negativ geladener Spalt (im folgenden Dimerspalt genannt), der aufgrund seiner Grösse einen Teil eines Peptids binden könnte.

Mittels Punktmutagenese-Studien am Wind-Protein konnte ich eine mögliche PipeBindestelle charakterisieren. Diese Charakterisierung erfolgte mit Hilfe eines Pipe-Translokationsassays. Dazu wurden COS7-Zellen mit entsprechenden Konstrukten transfiziert und anschliessend durch Immunfluoreszenz-Färbung untersucht. Wind-Wildtyp (Wind-WT) ist in der Lage, die Translokation von Pipe in den Golgi zu katalysieren. Bei Transfektion einiger Punktmutations-Konstrukte mit Pipe konnte diese Translokation nicht beobachtet werden: dieses betraf in der Thioredoxin-Domäne ein Cluster von drei oberflächlich gelegenen Tyrosinen, die innerhalb der PDI-D Subfamilie hoch konserviert sind.

Durch Generierung von Deletionskonstrukten des Wind-Proteins wurde herausgefunden, dass auch die D-Domäne an der Interaktion mit Pipe beteiligt ist. So war z.B. WindABC, ein Konstrukt, bei dem die D-Domäne deletiert war, nicht in der Lage, Pipe zu transportieren.

Die Thioredoxin-Domäne und die D-Domäne sind beide wichtig für die Translokation von Pipe in den Golgi. Werden diese Abschnitte jedoch separat in COS7-Zellen exprimiert, so 
konnte kein Transport von Pipe festgestellt werden. Ein Transport wurde erst beobachtet, wenn die Thioredoxin-Domäne über den Linker kovalent mit der D-Domäne verbunden war.

Zusätzlich fand ich heraus, dass die D-Domäne von Wind durch diejenige von ERp28, dem Wind-Homolog der Maus ersetzt werden konnte. ERp28 hingegen war nicht in der Lage, Pipe zu prozessieren.

Weiterhin fanden wir heraus, dass das CTGC-Tetrapeptid in Wind redox-inaktiv ist und Wind somit als redox-unabhängiges Chaperon fungieren kann. 


\section{Einleitung}

\subsection{Das Endoplasmatische Retikulum und der Golgi-Apparat}

Das Endoplasmatische Retikulum (ER) ist ein labyrintartiges, membranumschlossenes Zellkompartiment im Zytosol eukaryotischer Zellen und nimmt eine wichtige Rolle bei der Synthese von Lipiden und Proteinen ein. Die ER-Membran grenzt das Lumen vom Zytosol ab und vermittelt den Transport von Molekülen zwischen diesen zwei Kompartimenten. Das ER kann morphologisch und funktionell unterteilt werden: zum einen gibt es das glatte ER, in welchem Lipoproteine produziert werden und Detoxifikations-Vorgänge erfolgen, zum anderen das rauhe ER, welches Ribosomen auf seiner cytosolischen Oberfläche aufweist; hier werden auch Membranproteine und Sekretionsproteine synthetisiert.

Als Golgi-Apparat (Entdecker C. Golgi, 1844-1926) wird die Gesamtheit aller Diktyosomen in einer Zelle bezeichnet. Diese bestehen aus einem Stapel von mehreren Membranzisternen, die mit zahlreichen Vesikeln assoziiert sind. Die ER-zugewandte Seite wird als cis-Seite, die gegenüberliegende Seite als trans-Seite bezeichnet. Der Transport vom ER zum Golgi erfolgt über Vesikel, die sich am ER abschnüren und mit dem cis-Golgi fusionieren. Im GolgiApparat werden Oligosaccharidseitenketten von Glykoproteinen modifiziert. Nachdem ein Protein im Golgi modifiziert wurde, wird es dort sortiert und entsprechend seines Bestimmungsortes in Vesikel zur Plasmamembran oder zu den Lysosomen weitergeleitet.

\subsubsection{Protein-Faltung}

Bei der Faltung von sekretorischen Proteinen unterscheidet man zwischen posttranslationaler und co-translationaler Faltung. Im ersten Fall erfolgt die Faltung nach der Protein-Synthese; im zweiten Fall assoziiert das Protein während der Synthese mit der ERMembran. Proteine, die in das ER transloziert werden, werden co-translational gefaltet. Für die Assoziation mit der Membran braucht das Protein ein Signal, welches vom Translokationssystem erkannt wird. Dieses Signal ist ein Sequenzmotiv, welches am N-Terminus lokalisiert ist, nicht zum reifen Protein gehört und meist einen hydrophoben Kern aufweist. Während der Translokation wird dieses Motiv von einer Signalpeptidase abgespalten. Im Lumen erfolgt die Proteinfaltung sowie post-translationale Modifikationen wie Glykosylierung und Disulfid-Brückenbildung. 
Die Protein-Faltung findet durch Interaktionen zwischen hydrophoben Seitenketten eines Proteins statt. Jede hydrophobe Kette kann mit einer anderen aggregieren. Dieses geschieht zufällig und ergibt keine richtige Konformation des Proteins. So findet man im ER eine grosse Anzahl von Faltungshelfern wie Chaperone und Foldasen vor. Chaperone helfen bei der korrekten Assemblierung durch Verhinderung einer inkorrekten Konformation oder Aggregation.

$\mathrm{Zu}$ den Foldasen gehören u.a. Peptidyl-prolyl-Isomerasen (PPIasen, Freskgard et al., 1992) und Mitglieder der Protein Disulfid-Isomerase Familie (PDI). Beide dienen der Beschleunigung der geschwindigkeitsbestimmenden Isomerisierung. Als Chaperon findet sich im ER z.B. BiP, das Immunglobulin heavy chain-Bindeprotein (Kassenbrock et al., 1988). BiP erkennt falsch gefaltete Proteine bzw. Proteinuntereinheiten, die sich noch nicht zu einem Komplex assembliert haben, und verhindert deren Aggregation und somit die Degradation. Weiterhin befinden sich die 2 Lektine Calreticulin (Hebert et al., 1996) und Calnexin (Bergeron et al., 1994) im ER. Ihre Funktion ist es, an Oligosaccharide unzureichend gefalteter Proteine zu binden und sie im ER zurückzuhalten.

Zusätzlich verfügt das ER über einen optimalen $\mathrm{pH}$-Wert, sowie eine optimale Umgebung für die oxidative Proteinfaltung. So ist der oxidative Status, der durch das Verhältnis von reduziertem Glutathion (GSH) zu oxidiertem Glutathion (GSSG) definiert wird, im ER erheblich höher als im Cytoplasma [GSH]:[GSSG] 2:1 (Hwang et al., 1992). Dieses macht das ER zu einer optimalen Umgebung für Redox-Reaktionen, die für die oxidative Faltung von Proteinen notwendig sind.

Trotz Einsatz dieser Faltungshelfer kann es zu einer Akkumulation von falsch gefalteten Proteinen im ER kommen. In diesem Fall wird ein Prozess ausgelöst, der als unfolded protein response (UPR) bezeichnet wird (Chapman et al., 1998). Dabei wird die Transkription von Genen, die für Chaperone kodieren, hochreguliert. Dieses Phänomen wurde zuerst am Influenza Hämagglutinin beobachtet (Kozutsumi et al., 1988). Anhand des Hämagglutinins konnte gezeigt werden, dass ein mutiertes Hämagglutinin aufgrund von Fehlfaltung des Proteins im ER reteniert wird und es hierdurch zu einer Induktion von Genen verschiedener ER-Proteine kommt, die eine Protein-Faltung erleichtern, z.B. BiP und PDI.

Darüberhinaus findet eine Qualitätskontrolle im ER statt. So können richtig gefaltete Proteine das ER verlassen, wohingegen falsch gefaltete Proteine im ER zurückgehalten werden. Sie werden von Chaperonen gebunden und in die richtige Konformation gefaltet. Gelingt dieses nicht, so startet ein Abbauweg, der sich ERAD nennt (ER-assoziierte Degradation). Dabei 
werden die nicht- oder falsch gefalteten Proteine zurück ins Zytosol transloziert, wo sie eine Reihe von Modifikationen wie Deglykosylierung und Ubiquitinierung erfahren, bevor sie schliesslich im Proteasom abgebaut werden.

Alle genannten Mechanismen dienen dazu, nicht- oder falsch gefaltete Proteine nicht an ihren Bestimmungsort gelangen zu lassen.

\subsection{Protein Disulfid Isomerasen}

\subsubsection{Charakteristika der PDI}

Protein Disulfid Isomerasen (PDI) gehören zur Thioredoxin-Superfamilie.

In den frühen 60er Jahren wurde PDI aus Leber isoliert (Goldberger, 1963), ist aber in vielen Geweben und Organen vorhanden (Bjelland, 1987). Dabei handelt es sich um ein ERluminales Protein von ca. 510 Aminosäuren mit einer KDEL-Retrieval-Sequenz, einer Sequenz, die den Rücktransport von Proteinen z.B. vom Golgi ins ER ermöglicht. PDI ist innerhalb der Spezies hochkonserviert (Hefe, Säuger) und liegt in unterschiedlichen Oligomerisierungsformen vor, z.B. als Homodimer (Freedman, 1994) oder als Tetramer (Gilbert, 1998). Die Funktion dieser Proteine besteht darin, die Formation, Reduktion sowie Isomerisierung von Disulfidbrücken zu katalysieren (Freedman, 1994) und im Falle von PDI als Chaperon zu dienen (Noiva und Lennarz, 1992). Die Isomeraseaktivität beruht in diesem Molekül in erster Linie auf der Reaktivität des N-terminalen Cysteins der CGHC-Boxen (Chivers et al., 1996).

PDI setzt sich aus 2 redox-aktiven (a, a') sowie 2 inaktiven Untereinheiten (b, b') zusammen (s. Abb. 1). Die a-Domänen weisen hohe Sequenz-Ähnlichkeiten mit Thioredoxin auf. Sowohl die a- als auch die a'-Domäne verfügen über eine Kopie des CGHC-Motivs (schwarzer Balken in der Abb. 1) und sind redox-aktiv. Die b- und b'-Domänen sind redoxinaktiv.

Sämtliche a- und b-Domänen setzen sich aus ABC-Boxen zusammen. Diese Boxen sind Strukturelemente im Thioredoxin (Ferrari et al., 1998). Desweiteren liegt am C-Terminus eine saure Region vor dem KDEL-Signal (Macer, 1988). Diese Region c hat eine hohe Calciumbindungs-Affinität. Sie wird als eine mögliche Peptid-Bindestelle diskutiert (Noiva et al., 1993). 


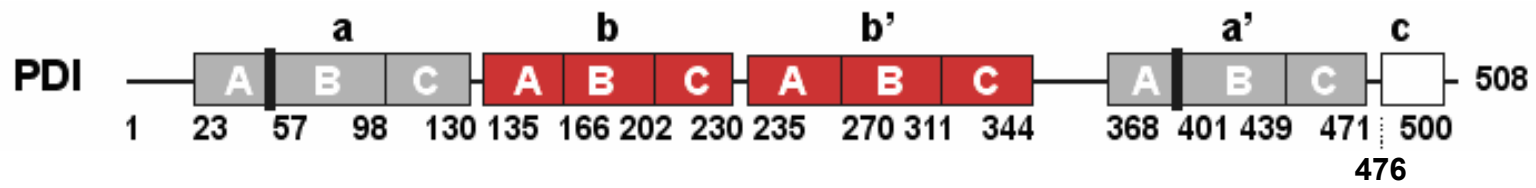

Abb. 1: Struktur von PDI. Angegeben sind die verschiedenen Untereinheiten a, a' (jeweils mit einer intakten Kopie des CGHC-Motivs, ihren Boxen (A, B, C) und der Aminosäuren des Proteins, angefangen mit 1 (Met). Bild reproduziert mit freundlicher Genehmigung von Dr. D. Ferrari.

Der charakteristische Thioredoxin-Fold (s. Abb. 2) setzt sich aus einer Anordnung von $\beta 1-\alpha 1-$ $\beta 2 \alpha 2-\beta 3-\alpha 3-\beta 4-\beta 5-\alpha 4$ zusammen. Ausser dem $\beta 4$ sind alle $\beta$-Faltblätter parallel angeordnet und bilden somit einen zentralen Kern.

(a)

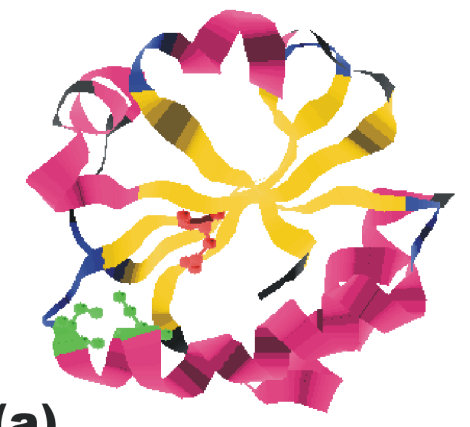

(b)

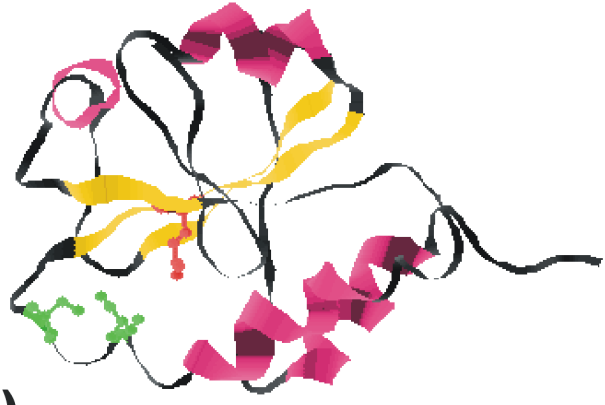

Abb. 2: Vergleich der 3D-Struktur von Thioredoxin mit dem Thioredoxin-Motiv von PDI-Proteinen. (a) Struktur von E.coli-Thioredoxin (Katti et al., 1990). (b) a-Domäne eines humanen PDI-Proteins (Kemmink et al., 1997). Die Cysteine im redox-aktiven-Motiv sind grün dargestellt, Asp-26 (rot) in Thioredoxin und Glu-30 in PDI (rot). Alpha-Helices waren in violett gezeigt, B-Faltblätter in gelb (Ferrari und Söling, 1999).

PDI ist auch Untereinheit im Enzym Prolyl-4-4hydroxylase (P4H), welches an der Synthese von Kollagenen beteiligt ist (Philajaniemi et al., 1987), sowie im mikrosomalen Triglycerid Transferprotein (MTP) (Wetterau, 1990). In beiden Fällen verhindert die PDI-Untereinheit die Aggregation der jeweiligen funktionellen Untereinheiten.

\subsubsection{Redox-Isomerase-Funktion von PDI}

Für die Reifung vieler Proteine ist die Bildung von Disulfid-Brücken ein entscheidender Faktor. Diese Disulfid-Brücken sind wichtig für die Stabilität, die richtige Struktur und/ oder die Funktion eines Proteins. Die Faltung eines Proteins in seinen nativen Zustand wird durch das Vorhandensein von fehlgepaarten S-S-Brücken verhindert.

Im Gegensatz $\mathrm{zu}$ früheren Angaben ist die S-S-Bildung nicht von Glutathion abhängig, sondern wird durch das Protein Ero1p (Frand und Kaiser, 1998) im Zusammenspiel mit PDI erreicht. Ero1p ist ein neues, konserviertes FAD-abhängiges Enzym, welches zwei Homologe 
im Menschen hat (hERO1- $\alpha$ und $\beta$ ). Es verfügt über 7 Cysteine, die am Elektronen-Transfer beteiligt sind und hat keine Homologien zu Redoxenzymen.

Ero1p wird durch molekularen Sauerstoff oxidiert und gilt als spezifisches Oxidans für PDI. PDI oxidiert dann direkt die S-S-Bildung in dem zu faltenden Protein.

Auch in E.coli ist ein ähnlicher Prozess zu beobachten: die Bildung und Isomerisierung von Disulfid-Brücken geschieht durch die Dsb-Proteine. Im oxidativen Weg dient DsbA, ein kleines periplasmatisches Protein von $21 \mathrm{kDa}$, als ein direkter Katalysator der Disulfidbrückenbildung in neu synthetisierten periplasmatischen Proteinen. Um als Katalyst der S-S-Brückenbildung zu agieren, muss DsbA reoxidiert werden. Dieses geschieht durch das $21 \mathrm{kDa}$ grosse Membranprotein DsbB.

DsbA wird dabei selbst reduziert und überträgt seine Elektronen auf DsbB, um wieder seinen oxidierten Status zu erlangen. Unter aeroben Bedingungen überträgt DsbB seine Elektronen auf Ubiquinon, welches sie weiter auf Cytrochrom-Oxidasen und schliesslich molekularen Sauerstoff überträgt (Bader et al., 1998). Unter anaeroben Bedingungen erfolgt die Elektronenübertragung auf Menaquinon, welches sie weiter gibt an Elektronenakzeptoren wie Fumarat-Reduktase oder Nitrat-Reduktase (Bader et al., 1998).

Zwei weitere Proteine DsbC (Missiakes et al., 1994) und DsbG (Andersen et al., 1997) sind bekannt. Beides sind Disulfid-Isomerasen. Um fehlgepaarte Disulfide zu attakieren, müssen sie in reduzierter Form vorliegen. Dieses wird durch das Protein DsbD gewährleistet, dabei wird DsbD selbst reduziert. Die Reduktion von DsbD erfolgt durch Thioredoxin, welches wiederum durch die Thioredoxin-Reduktase in Gegenwart von NADPH reduziert wird.

\subsubsection{Mitglieder der PDI-Familie}

Mittlerweile wurden eine Vielzahl von Proteinen mit strukturellen und funktionellen Ähnlichkeiten entdeckt und der PDI-Familie zugeordnet (PDI-ähnliche Proteine, siehe Abb. 3). Dazu gehört neben PDI auch ERp57, welchem die C-terminale saure Region fehlt und statt des KDEL ein QEDL-Signal aufweist (Bennet et al., 1988). Es ist weniger redox-aktiv als PDI. ERp57 und PDI sind auf Aminosäurebasis zu 33 \% identisch. ERp57 interagiert im Unterschied zu PDI nicht mit unglykosylierten, sondern mit ungefalteten monoglykosylierten Glycoproteinen ohne Beteiligung von Disulfiden (Oliver et al., 1997) und möglicherweise indirekt durch Interaktionen mit den Lektinen Calnexin (Wada et al., 1991), einem Membran- 
gebundenen $65 \mathrm{kDa}$ grossen Protein, oder Calretikulin, einem löslichen ER-Protein (Van der Wal et al., 1998). ERp57 selbst hat keine Lektin-Eigenschaften. Von Calnexin und Calretikulin ist bekannt, dass sie nur mit monoglykosylierten Proteinen interagieren (Helenius et al., 1997).

Ein weiterer Vertreter der PDI-Familie ist ERp72. Dieses Protein verfügt im Vergleich zu PDI über 3 aktive Thioredoxin-Boxen, ist weit verbreitet und verfügt über eine CalciumBindungsaffinität (V. Nguyen et al., 1989).

Bei Erp18 handelt es sich um das kleinste redox-aktive PDI-Protein (Lundström-Ljung et al., 1995).

PDIr (Hayano et al., 1995) wird bevorzugt in Zellen exprimiert, die Proteine sekretieren. Auffällig ist die Struktur von PDIr: jede der 3 a-Domänen hat ein eigenes Thioredoxinähnliches Tetrapeptid: -CSMC-, -CGHC- und -CPHC-. Es wird spekuliert, dass jede aDomäne verschiedene Redox-Eigenschaften besitzt, abhängig vom Substrat (Ferrari et al., 1999).

Ein ähnliches Protein, ERdj5, mit verschiedenen CXXC-Motiven wurde 2003 beschrieben (Hosoda et al., 2003; Cunnea et al., 2003): ERdj5 kommt in sekretorischen Zellen vor und verfügt über Domänen, die Ähnlichkeit mit Domänen in DnaJ, PDI und Thioredoxin aufweisen.

PDIp (Desilva et al., 1996) ist pankreas-spezifisch. Wie ERp57 fehlt in diesem Protein die Cterminale saure Region. Die Übereinstimmung in der Aminosäure-Sequenz mit PDI beläuft sich auf $40-45 \%$. 


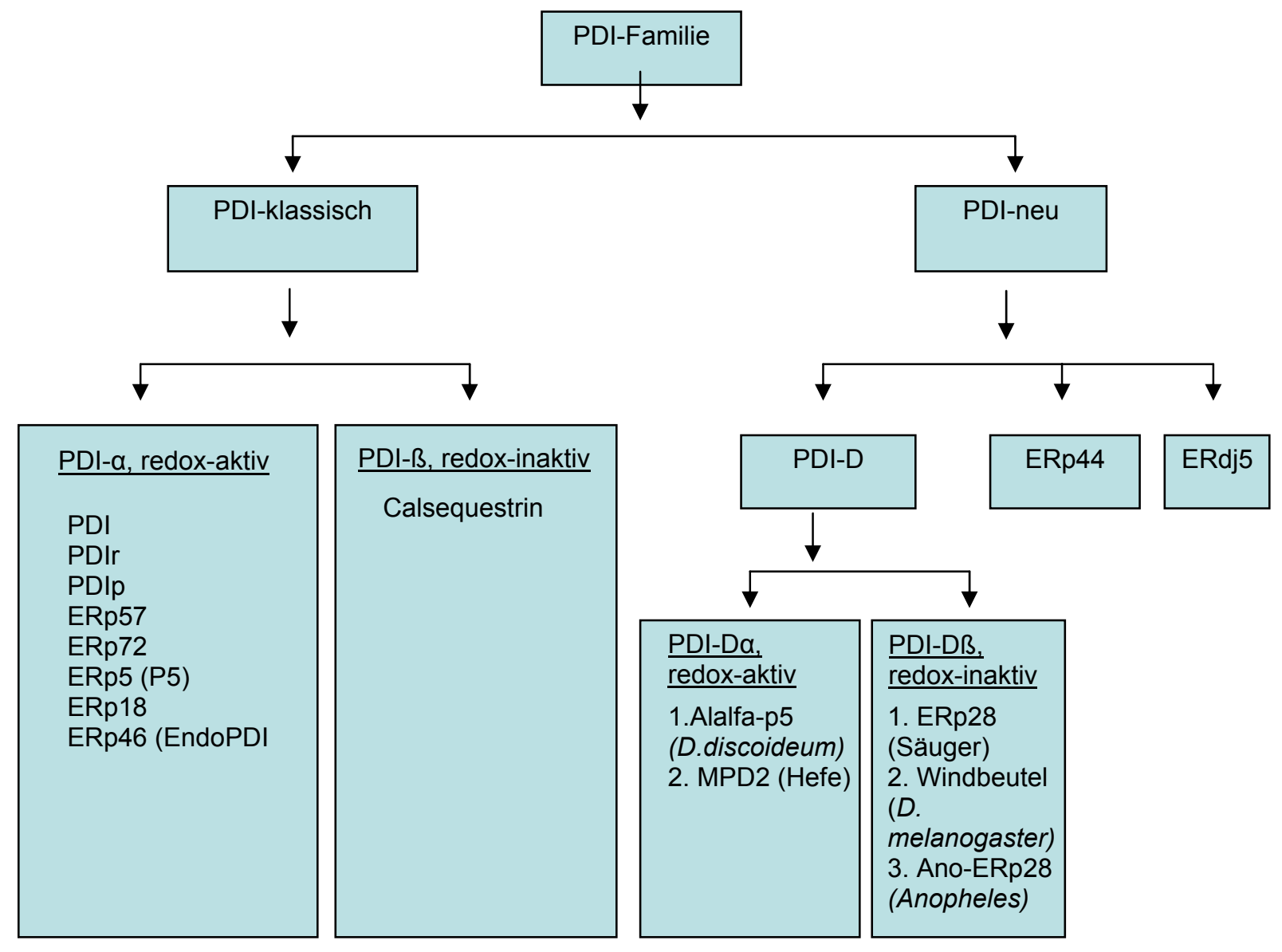

\section{Abb.3: Schema PDI-ähnlicher Proteine}

Bei manchen Proteinen wurden neben den Thioredoxin-ähnlichen Domänen auch andere Domänen identifiziert. So z.B. bei ERp28, das erst vor wenigen Jahren entdeckt wurde (Demmer et al., 1997; Ferrari et al., 1998). Dieses Protein enthält neben der redox-inaktiven Thioredoxin-ähnlichen Domäne eine sogenannte D-Domäne am C-Terminus. Dieses ist eine Domäne, welche 110 Aminosäuren lang ist und ausschliesslich $\alpha$-Helices als Strukturelement aufweist.

Es wurden eine Reihe von homologen Proteinen zu ERp28 gefunden. So wurden sie in die Klasse der PDI-D-Proteine (s. Abb. 4) eingeordnet, bei welchen man weiter zwischen PDI-D$\alpha$ (redox-aktiv) und PDI-D- $\beta$ (redox-inaktiv) unterteilt. Mitglieder der PDI-D- $\alpha$ Proteine sind im Durchschnitt 360 Aminosäuren lang. Sie verfügen über zwei redox-aktive ThioredoxinDomänen sowie eine D-Domäne. Auffällig ist weiterhin, dass bei vielen Vertretern der PDID- $\alpha$ Unterfamilie ein klassisches C-terminales Retrieval-Signal fehlt.

Im Vergleich dazu sind Mitglieder der PDI-D- $\beta$ Familie um 100 Aminosäuren kürzer. Sie besitzen nur eine Thioredoxin-Domäne, die inaktiv ist. Bei Xenopus laevis ist bisher nur die 
D-Domäne bekannt.

Über die Funktion der D-Domäne wird noch spekuliert. Es gibt Hinweise darauf, dass die DDomäne der Retention im ER dient. So wurde von Monnat et al. (2000) beschrieben, dass das Homolog von PDI in Dictyostelium (Dd-PDI) trotz fehlender KDEL-Sequenz im ER verbleibt. Die letzten 57 Aminosäuren am C-Terminus waren in der Lage, ein GFPFusionsprodukt im ER zu lokalisieren.

\begin{tabular}{lllllll}
\hline Protein & Grösse & Domänen & Anzahl & der & Retrieval- & Literatur \\
& - & Domänen & sequenz & \\
& Struktur & a $\quad b \quad a+b$ & &
\end{tabular}

\section{PDI-D $\alpha$}

\begin{tabular}{|c|c|c|c|c|c|c|c|}
\hline M. sativa $\mathrm{P} 5$ & 364 & $a^{\circ}-a-D$ & 2 & 0 & 2 & n.b. & Shorrosh et al., (1992) \\
\hline A. thaliana & 361 & $a^{\circ}-a-D$ & 2 & & 2 & n.b. & unveröffentlicht \\
\hline N. tabacum PDI & 359 & $a^{\circ}-a-D$ & 2 & & 2 & n.b. & unveröffentlicht \\
\hline O. sativa (ESTs) & & $a^{\circ}-a-D$ & 2 & 0 & 2 & n.b. & unveröffentlicht \\
\hline $\begin{array}{l}\text { P. balsamiferal } \\
\text { P. tremula (ESTs) }\end{array}$ & n.v. & $a^{\circ}-a-D$ & 2 & 0 & 2 & n.b. & unveröffentlicht \\
\hline D. discoideum & 363 & $a^{\circ}-a-D$ & 2 & 0 & 2 & n.b. & Monnat et al., (1997) \\
\hline
\end{tabular}

Dd-PDI

$\begin{array}{llllllll}\text { A. niger TigA } & 359 & \mathrm{a}^{\circ} \text {-a-D } & 2 & 0 & 2 & \text { KDEL } & \text { Jeenes et al., (1997) } \\ \text { N. crassa } \text { ER38 } & 369 & \mathrm{a}^{\circ} \text {-a-D } & 2 & 0 & 2 & \text { KEEL } & \text { Jeenes et al., (1997) } \\ \text { S. pombe pdi2 } & 359 & \mathrm{a}^{\circ} \text {-a-D } & 2 & 0 & 2 & & \text { unveröffentlicht } \\ \text { S. cerevisiae } & 277 & \text { a-D } & 1 & 0 & 1 & \text { HDEL } & \text { Tachikawa et al., (1997) }\end{array}$
$\operatorname{mpd} 2$

\section{PDI-Dß}

\begin{tabular}{|c|c|c|c|c|c|c|c|}
\hline H. sapiens ERp28 & 261 & $b-D$ & 0 & 1 & 1 & KEEL & Ferrari et al., (1998) \\
\hline norvegicus & 260 & $b-D$ & 0 & 1 & 1 & KEEL & Demmer et al., (1997) \\
\hline \multicolumn{8}{|l|}{ ERp29 } \\
\hline musculus & 260 & $b-D$ & 0 & 1 & 1 & KEEL & unveröffentlicht \\
\hline \multicolumn{8}{|l|}{ (ESTs) } \\
\hline D. melanogaster & 257 & $b-D$ & 0 & 1 & 1 & KEEL & Konsolaki et al., (1998) \\
\hline X. laevis & n.v. & $?-\mathrm{D}$ & $?$ & 1 & $?$ & KEEL & unveröffentlicht \\
\hline
\end{tabular}

Abb. 4: Vertreter der PDI-D-Proteine mit ihren Charakteristika. N.v. bedeutet nicht veröffentlicht, n.b. nicht bekannt. 
Ein weiterer Vertreter der PDI-D-Proteine ist das Windbeutel-Protein von Drosophila melanogaster. Dieses wird im Folgenden näher beschrieben.

\subsection{Funktion von Wind}

Die dorso-ventrale Entwicklung (DV-Entwicklung) in D. melanogaster ist abhängig von zwei sequentiell wirkenden Signaltransduktions-Kaskaden, welche in der Eihülle und im Ei ablaufen (Konsolaki und Schüpbach, 1998, s. Abb. 5). Diese ist abhängig von Zell-ZellInteraktionen im Ovar und findet statt durch Aktivierung von Transmembran-Rezeptoren durch sekretierte Liganden.

Die Ausbildung der DV-Polarität geschieht während der Oogenese und erfordert eine Kommunikation zwischen Oozyte und Follikelzellen im Ovar.

Die Oozyte sendet ein Signal zur Dorsalisierung an die Follikelzellen, welches von den Follikelzellen über das EGF-Rezeptor Homolog Torpedo EgfR (D. melanogaster Homolog zu humanem EGF-R) empfangen wird. Torpedo wird in allen Follikelzellen exprimiert, aber nur in Zellen aktiviert, die ein Signal von Gurken, einem Homolog zu EGF, erhalten. Gurken mRNA wird im Bereich zwischen der Oozyte und den Follikelzellen synthetisiert. Das Produkt Gurken (Neumann-Silberberg et al., 1993) lagert sich um den Oozytenkern herum an und wird in Follikelzellen sekretiert. Dieses hat 2 Folgen: (1) so wird durch die Änderung in den Follikelzellen die Ventralisation verhindert und (2) ein zweiter Weg aktiviert. Dabei werden die Signale von den Follikelzellen zum Embryo weitergeleitet. Unter Beteiligung von 11 Genen der Dorsalgruppe kommt es zur Ausbildung der dorsoventralen Achse im Embryo. Das Signal der Follikelzellen führt zur Aktivierung des Toll-Rezeptors im ventralen Bereiches der Eizelle. Diese Aktivierung wird durch Spätzle vermittelt, dessen abgespaltene, aktive Form nur auf der ventralen Seite im Embryo vorliegt. Spätzle selbst wird durch eine proteolytische Kaskade von Serin-Proteasen (Gastrulation defekt GD, snake und easter) aktiviert.

Drei der Gene der Dorsalgruppe sind in den Follikelzellen vorhanden: Wind, Pipe und Nudel. Wind wird nur in den Follikelzellen, die über der Oozyte liegen, exprimiert.

Bei Wind handelt es sich um ein ER-residentes, PDI-verwandtes Protein (257 Aminosäuren), welches über eine Signalsequenz am N-Terminus verfügt. Wind ist erforderlich für die richtige Lokalisation von Pipe in den Golgi-Apparat (Konsolaki et al., 1998).

Pipe ist ein Homolog zu 2-O-Sulfotransferase (Seergev, 2001) und ein wichtiger Faktor in der 
Dorsoventral-Entwicklung (Sen, 1998).

Nudel kodiert für ein Protein mit einer extrazellulären Matrixdomäne und einer Serinprotease Domäne (Hong und Hashimoto, 1995). Es wird spekuliert, dass Nudel möglicherweise durch Follikelzellen sekretiert und in den perivitellinen Raum eingelagert wird.

Im Gegensatz zu Wind und Nudel ist Pipe nur in den ventralen Follikelzellen vorhanden, die Expression in den dorsalen Follikelzellen wird durch EGFR verhindert (Sen, 1998).

Im Golgi-Apparat modifiziert Pipe ein bis jetzt unbekanntes Proteoglycan, das für den weiteren Verlauf der Dorsoventral-Signalkaskade wichtig ist.

In D. melanogaster Wind Mutanten wird Pipe im ER reteniert und nicht in den Golgi-Apparat transloziert.

In einem heterologen Expressionssystem (COS7-Zellen) zeigt Pipe eine ER-Verteilung. Bei Co-Expression von Wind wird Pipe in den Golgi transportiert (Sen et al., 1998). Wind ist also für die subzelluläre Verteilung von Pipe erforderlich und könnte als Chaperon dienen.

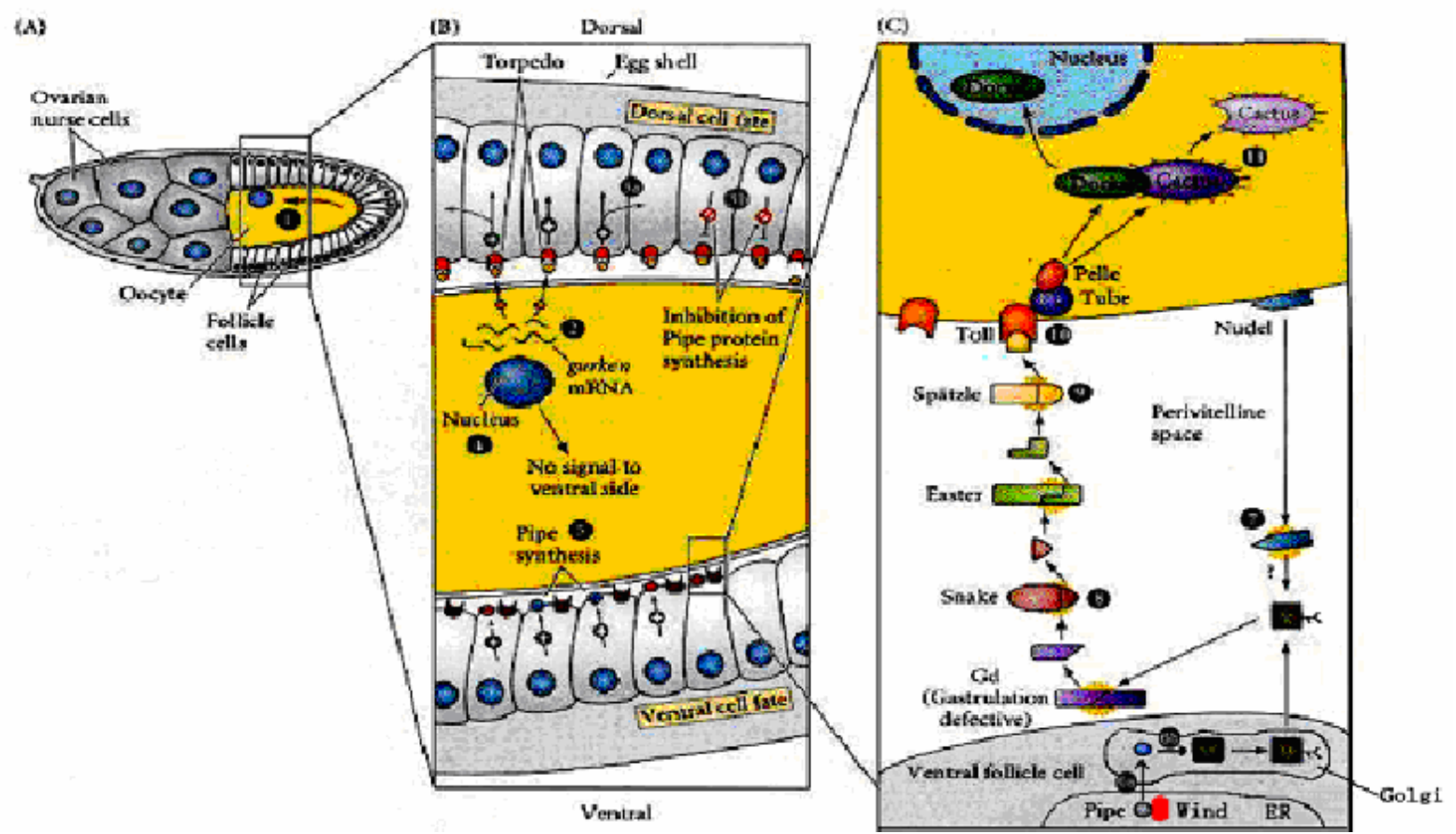

Abb.5: Dorsoventrale Entwicklung in D. melanogaster. Auszug aus Molecular biological course, Fritz Aberger, modifiziert, mit freundlicher Genehmigung von Dr. Q. Ma.

1: Der Oozytennukleus wandert zur dorsalen Seite der Oozyte. Gurken mRNA wird synthetisiert, welche im Bereich zwischen Nukleus und Follikel-Zellen verbleibt.

2: Gurken Signale werden translatiert. Während der Mid-Oogenese wird Gurken-Protein auf Torpedo-Protein übertragen.

3a: Durch das Torpedo-Signal werden die Follikel-Zellen zur Differenzierung einer dorsalen Morphologie veranlasst.

3b: Synthese von Pipe wird in Follikel-Zellen inhibiert.

4: Gurken-Protein wandert nicht zur Ventralseite.

5: Ventrale Follikelzellen synthetisieren Pipe.

6a: Wind ist indispensabel für Pipe, um vom ER zum Golgi zu translozieren. 
6b: in ventralen Follikel-Zellen modifiziert Pipe einen bis jetzt unbekannten Faktor X.

7: Durch Interaktion von Nudel und dem Faktor X wird GD-Protein (Gastrulation-defizient) gespalten.

8: das aktivierte GD spaltet das Snake-Protein; Aktiviertes Snake spaltet Easter.

9: aktiviertes Easter spaltet Spätzle, aktiviertes Spätzle bindet an toll-Rezeptor-Protein.

10: Toll-Aktivierung aktiviert Tube und Pelle, welche Cactus phosphorylieren. Cactus wird abgebaut und von Dorsal freigesetzt.

11: Dorsal gelangt in den Nukleus und führt zur Ventralisation der Zelle.

\subsection{Struktur von Wind}

Wind kristallisiert als Homodimer (s. Abb. 6). Das Wind Dimer hat eine Grösse von 2x 27 kDa. Der N-terminale Anteil, entsprechend den Strukturmodulen A, B und C, besteht aus 118 Aminosäuren mit einer $ß \alpha ß \alpha \beta \alpha ß ß \alpha$-Struktur. Alle $\beta$-Faltblätter - ausser $\beta 4$ - sind parallel angeordnet und bilden einen zentralen Kern, der von den vier $\alpha$-Helices umgeben wird. Diese Anordnung ist charakteristisch für PDI-Proteine und Thioredoxin-verwandte Proteine (Katti et al., 1990).

Das C-terminale Ende von 107 Aminosäuren, welches die D-Domäne repräsentiert, besteht ausschliesslich aus $\alpha$-Helices, welche anti-parallel angeordnet sind. Der N-terminale ABCTeil und die D-Domäne werden über einen 11 Aminosäuren langen Linker miteinander verbunden (AS 140-150).

Die Homodimerisierung wird durch ein head-to-tail-Arrangement der beiden N-Termini (AS 1-118) gebildet (Ma et al., 2003), ohne jegliche Beteiligung der D-Domänen. Das Dimerinterface ist fast symmetrisch und besteht vorwiegend aus Aminosäuren von ß1 (AS 24-34), in und hinter $\alpha 1$ (AS 37-43) sowie in und hinter $\alpha 2$ (AS 70-75). Für die Stabilisierung des Dimers sind hydrophobe Interaktionen und Wasserstoffbrücken-Bildung beteiligt. Die gesamte Dimerfläche beträgt ca. $758 \AA^{2}$, welches ca. 6,3\% der Oberfläche des Wind-Proteins entspricht.

Durch die Homodimerisierung entsteht ein tiefer, negativ geladener, hydrophiler Spalt von ca. 11x11x27 $\AA^{3}$. Der Spalt wird von Aminosäuren der ß3- und ß1-Faltblätter umgeben.

Das CTGC-Motiv von Wind liegt am Eingang zum Spalt so positioniert, dass es mit Cysteinen eines Substrates in der Spalte reagieren könnte.

Neben der Kristallisation wurde das Vorliegen eines Wind-Dimers auch durch multi-angle light scattering Messungen und size exclusion Chromatographie, in vitro und in vivo cross linking sowie native SDS-Gele von gereinigten, rekombinanten Wind, an welches ein Tag von 6 Histidinen am N-Terminus angehängt war, bestätigt. 

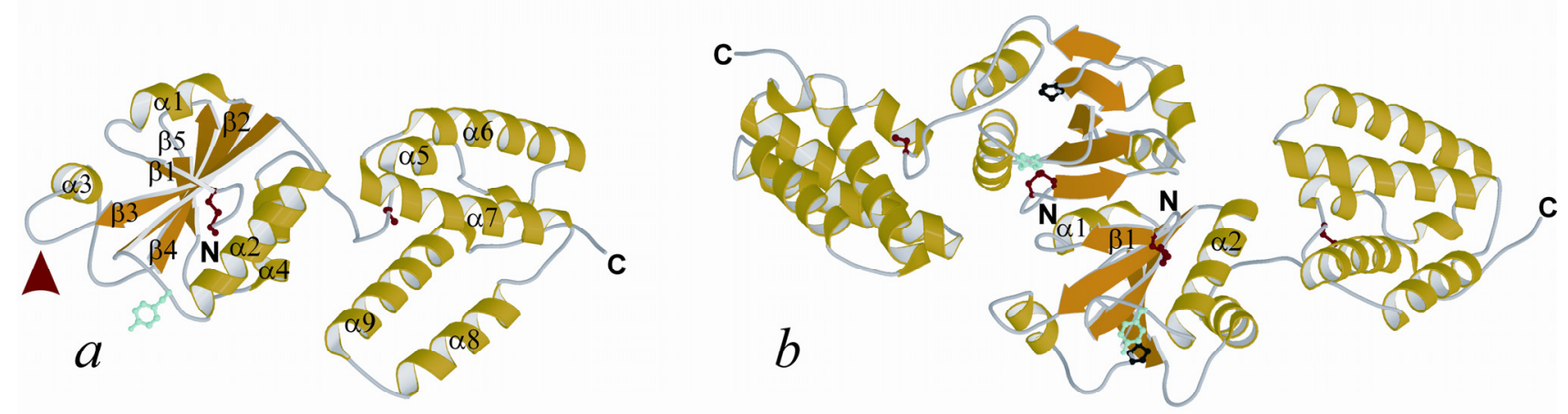

Abb. 6a und b: Struktur des Wind-Monomers und des Homodimers.

Abb 6a zeigt das Wind-Monomer, links die Thioredoxin-Domäne mit der charakteristischen Anordnung B $\alpha \beta \alpha \beta \alpha \beta B \alpha$ am N-Terminus, rechts die D-Domäne am C-Terminus. Der rote Pfeil zeigt die für PDI-Dß-Proteine charakteristische Peptidschleife. Sämtliche $\beta$-Faltblätter sind in gelb dargestellt, $\alpha$-Helices in grün. Die 3 Cysteine in Wind sind rot markiert; Tyr55 ist in blau dargestellt. In Abb. 6b ist das Homodimer abgebildet. Das Wind-Molekül ist im Vergleich zur Monomer-Darstellung (Abb. 6a) um $90^{\circ}$ gedreht. Die Strukturelemente (B1, $\alpha 1$ und $\alpha 2$ ), die an der Homodimerisierung beteiligt sind, sind markiert. Prolin106 ist in schwarz dargestellt.

Reproduziert mit freundlicher Genehmigung von Ma et al., 2003. 


\section{Ziel der Arbeit}

Das Ziel meiner Arbeit war die funktionelle Analyse des Wind-Proteins bei der Faltung und/ oder des Transports des Proteins Pipe, einem sekretorischen Protein von Drosophila melanogaster. Bis zum heutigen Zeitpunkt ist nur bekannt, dass Wind dadurch als ein Schlüsselfaktor in der Dorsoventral-Entwicklung der Fruchtfliege dient, dass es Pipe, ein weiteres essentielles Protein in der DV-Entwicklung, in den Golgi-Apparat transloziert.

Der Interaktionsmechanismus von Wind mit Pipe ist jedoch noch unklar. Weder von Wind als PDI-verwandtem Protein noch von PDI selbst oder anderen Mitgliedern der PDI-Familie wurde bisher eine exakte Substrat-Bindestelle beschrieben.

So stellt sich die Frage, ob Wind als Chaperon für Pipe fungiert und wie Wind in der Faltung bzw. und/ oder dem Transport von Pipe involviert ist. Um diesen Mechanismus aufzuklären, sollten auf Grundlage der in der Arbeitsgruppe Söling ermittelten 3D-Kristallstruktur (Ma et al., 2003) Punktmutationen in die Wind-Sequenz eingefügt werden. Dabei wurde der Schwerpunkt auf folgende Kriterien gelegt: mutiert wurden innerhalb der PDI-Familie bzw. der homologen Proteine ERp28/ ERp29 konservierte Aminosäuren auf der Oberfläche von Wind, die möglicherweise für Pipe zugänglich sein könnten. Durch weitere Punktmutationen sollte ebenso die Beteiligung der verschiedenen Domänen (Thioredoxin- und D-Domäne) und der Linkerregion am Pipe-Transport charakterisiert werden.

Desweiteren sollte der Raum im negativ geladenen Dimerspalt, sowie die Ladung des Dimerspalts selbst untersucht werden.

Durch diese Punktmutationen sollte eine konkrete Bindestelle für Pipe identifiziert werden.

Ebenso sollten Deletionskonstrukte von Wind angefertigt werden, um herauszufinden, welche Domänen von Wind an der Prozessierung von Pipe beteiligt sind.

Darüber hinaus sollte durch Deletionskonstrukte von Pipe die an der Interaktion mit Wind beteiligte Domäne charakterisiert werden. 


\section{Material}

\subsection{Versuchstiere}

Kaninchen (Chinchilla Bastard) zur Gewinnung von Antikörpern stammten von der Firma Charles River.

\subsection{Chemikalien}

Alle im folgenden aufgeführten Chemikalien wurden im höchstmöglichen Reinheitsgrad bzw. - wenn verfügbar - als ,für die Molekularbiologie/ Zellkultur

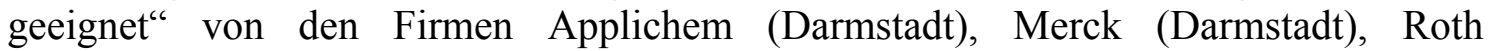
(Karlsruhe) oder Sigma (Deisenhofen) bezogen.

\subsection{Zellkulturreagenzien/-zusätze}

Zur Herstellung des Zellkulturmediums für COS-7-Zellen wurden Antibiotika Penicillin/ Streptomycin von Cambrex (Endkonzentrationen Penicillin $100 \mathrm{U} / \mathrm{ml}$; Streptomycin $0,1 \mathrm{mg} / \mathrm{ml}$ ) verwendet, ebenso wie Glutamin (Endkonzentration $2 \mathrm{mM}$ ) und Trypsin-ETDA (Endkonzentrationen Trypsin $500 \mathrm{mg} / \mathrm{L}$; EDTA $200 \mathrm{mg} / \mathrm{L}$;). Natrium-Pyruvat (Endkonzentration 1mM, ) wurde von GibcoBRL bezogen. Das Fetale Kälberserum (Endkonzentration FKS, 10 \%) stammte von der Firma BioChrom.

In einigen Versuchen wurde dem Zellkulturmedium der Proteasome-Inhibitor MG 132 (Carbobenzoxy-L-leucyl-L-leucyl-L-Leucinal)von Calbiochem $(10 \mu \mathrm{M})$ zugegeben. Zum Einfrieren von Zellen zur Konservierung wurde Dimethylsulfoxid (DMSO, 10 \%) von Sigma verwendet.

Der Transfektions-Mix für die Transfektion von Säugerzellen $(\mathrm{pH} 7,4)$ setzte sich wie folgt zusammen:

$\mathrm{KCl} 120 \mathrm{mM}, \mathrm{KH}_{2} \mathrm{PO}_{4} 10 \mathrm{mM}$, EGTA $2 \mathrm{mM}, \mathrm{MgCl}_{2} 5 \mathrm{mM}$, HEPES $25 \mathrm{mM}$ und $\mathrm{CaCl}_{2}$ $0,15 \mathrm{mM}$. Bis auf EGTA und HEPES (Gerbu) stammten alle genannten Substanzen von Merck. Dem Transfektions-Mix zuzufügende Substanzen ATP (2 mM) und GSH (5 mM) stammten von Sigma.

\subsection{Molekularbiologische Kits und Enzyme}

Von der Firma Quiagen stammte der RNeasy-Kit zur RNA-Isolierung sowie der RT-one Step-Kit.

Als DNA-Polymerasen wurden PanScript-Taq-Polymerase (Pan-Biotech) und PfuPolymerase (Promega) verwendet.

Desoxynukleotidtriphosphate (dNTPs) stammten von Pan-Biotech, Restriktionsendonukleasen von MBI Fermentas (St. Leon-Roth) oder von New England Biolabs (NEB). Weiterhin wurden DNA-modifizierende Enzyme wie T4-DNA-Ligase (MBI) und Shrimp Alkaline Phosphatase (SAP, Roche) und T4-Polynukleotid-Polymerase (NEB) verwendet. 
Von den Firmen Quiagen oder Macherey \& Nagel stammten sämtliche Kits zur Plasmid-Präparation (Mini-, Maxi-, endotoxinfreie Maxi-Kits), Plasmid-Extraktion aus Agarosegelen und zur Aufreinigung von PCR-Produkten.

Als Molekulargewichtsstandards für DNA-Agarosegele dienten ein $1 \mathrm{~kb}-$ Marker sowie ein 100 bp-Marker (jeweils MBI Fermentas). Der 6x Probenpuffer für DNA-Proben stammte ebenso von MBI Fermentas.

\subsection{Plasmid-Vektoren}

Als Vektor für die klonierten Konstrukte diente pEGFP-N1 der Firma Clontech. Für Zwischenklonierungen wurde der Phagemid-Vektor pBlueScript II (pBS') von Stratgene benutzt. Um Pipe mit einem Myc-Tag zu versehen, wurde ein pCMV-Vektor von Clontech verwendet.

\subsection{Bakterielle Stämme}

\begin{tabular}{|c|c|c|}
\hline Stamm & Genotyp/ Phenotyp & Firma \\
\hline DH5 $\alpha$ & $\begin{array}{l}\mathrm{F}-, \\
\Delta l a c \mathrm{U} 169, h s d R 17, \\
\operatorname{rec} A 1, \text { end } 11, \text { gyrA } 46 \text {, thi-1, } \\
\Delta(\text { lacZYA-argF }) \mathrm{U} 169\end{array}$ & Gibco-BRL \\
\hline XL1Blue & 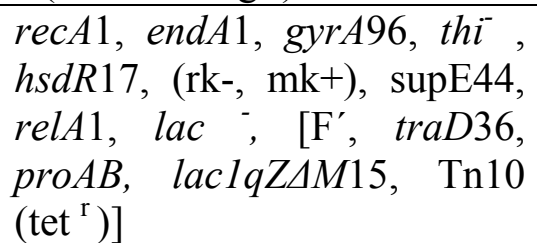 & Stratagene \\
\hline
\end{tabular}

\subsection{Medium für Bakterienkultur}

\subsubsection{Herstellung von Bakterienmedium}

Zur Anzucht von Bakterien wurde LB-Medium (Luria Bertani) verwendet, welches folgende Zusammensetzung hat:

LB-Medium: $10 \mathrm{~g}$ Bactotrypton (Roth)

$$
\begin{aligned}
& 5 \mathrm{~g} \text { Hefeextrakt (Roth) } \\
& 10 \mathrm{~g} \text { Natriumchlorid (Merck) } \\
& \text { aufgefüllt auf } 1 \text { L mit destilliertem Wasser, } \mathrm{pH} \text { 7,0. }
\end{aligned}
$$

Zur Herstellung von LB-Platten wurden dem LB-Medium pro Liter 15 g Agar-Agar (Roth) zugesetzt.

Flüssigmedium sowie die Lösung zur Herstellung von Platten wurden vor Gebrauch autoklaviert. 


\subsubsection{Additive für Bakterienmedium}

Die Antibiotika Ampicillin (ICN) und Kanamycin (Roth) wurden in Stocklösungen von jeweils $50 \mathrm{mg} / \mathrm{ml}$ in Aqua bidest angesetzt und filtriert. In den Versuchen wurden die Antibiotika mit einer Endkonzentration von $50 \mu \mathrm{g} / \mathrm{ml}$ eingesetzt.

Für Tetracyclin (Sigma) wurde eine 1000-fache Stocklösung in $50 \%$ (v/v) Ethanol angesetzt, die Endkonzentration betrug $12,5 \mu \mathrm{g} / \mathrm{ml}$.

$\mathrm{Zu}$ Selektivplatten wurden entsprechende Antibiotika erst zugesetzt, wenn die autoklavierte Lösung auf eine Temperatur unter $50{ }^{\circ} \mathrm{C}$ abgekühlt war.

\subsection{Säuger-Zelllinien}

Für sämtliche Zellkulturversuche wurden COS-7-Zellen (SV-40 transformierte Nierenzellen der Afrikanischen Grünen Meerkatze) der Fa. European Collection of Animal Cell Cultures verwendet. Die Grösse dieser Zellen liegt bei ca. 12 bis $20 \mu \mathrm{m}$. Die Zellen wurden bis zu 20 x passagiert.

\subsection{Oligonukleotide}

Oligonukleotide zur Amplifikation bzw. Mutagenese von doppelsträngigen DNA-Fragmenten (ds-DNA) wurden sowohl von MWG als auch von Invitrogen bezogen.

Die Lyophilisate wurden mit sterilem Wasser zu einer Konzentration von $100 \mathrm{pmol} / \mu 1$ gelöst.

\subsection{Reagenzien für die Proteinanalytik}

Als Protein-Molekulargewichtsstandards für SDS-Polyacrylamid-Gele wurden der vorgefärbte Peq-Gold (Peqlab) bzw. der Precision-Plus von BioRad aufgetragen.

Zur Herstellung von denaturierenden Polyacrylamid-Gelen (SDS-PAGE) wurden Natrium Dodecylsulfat (SDS, Merck), Ammoniumpersulfat (APS) und 1,2-Bis(dimethylamino)-Ethan (TEMED) von Sigma, Acrylamid-Bisacrylamid (Verhältnis $29: 1,30 \%$ in Wasser) und Dithiotreitol (DTT) von Roth bezogen.

Der Proteintransfer erfolgte auf Nitrocellulose-Membranen der Firma Schleicher \& Schüll.

Sekundäre Cy-3-gekoppelte Anti-Kaninchen Antikörper für Immunfluoreszenz stammten von Jackson Immunoresearch, Antikörper zur Identifizierung von Proteinen auf Nitrocellulose wurden von Dianova erworben (Peroxidase gekoppelt). Der GFPAntikörper aus Kaninchenserum stammte von der Göttinger Firma Sysy.

Der cross-linker Disuccinimidyl Suberat (DSS) stammte von Pierce. 


\section{Methoden}

\section{$\underline{\text { 5.1. Immunisieren von Kaninchen }}$}

Die Immunisierung wurde von Mitarbeitern der tierexperimentellen Abteilung des Max-Planck-Instituts folgendermassen durchgeführt: vor Beginn der Immunisierung wurden dem Tier 5 - $10 \mathrm{ml}$ Blut zur Gewinnung von Präimmunserum abgenommen. Dieses diente der Überprüfung auf Spezifität der später hergestellten Antikörper.

$60-100 \mu \mathrm{g}$ Antigen (von Dr. D. Ferrari bakteriell exprimiertes und gereinigtes WindProtein) wurden in $1 \mathrm{ml}$ PBS gelöst und mit $1 \mathrm{ml}$ komplettem Freund'schen Adjuvans gemischt. Die Injektion dieser Lösung wurde an den Kaninchen subkutan an 6 Stellen im Rücken vorgenommen. Nach 14 Tagen erfolgte eine Booster-Injektion wie oben beschrieben, jedoch mit inkomplettem Freund'schen Adjuvans. Nach weiteren 14 Tagen erfolgte die Abnahme von $5 \mathrm{ml}$ Blut, von welchem der Antikörper-Titer bestimmt wurde und gleichzeitig die 2. Booster-Injektion. Nach weiteren 14 Tagen wurde wiederum der Titer bestimmt und eine 3. Booster-Injektion durchgeführt.

Wenn ein zufriedenstellender Titer erreicht worden war, wurden $20 \mathrm{ml}$ Blut abgenommen, oder die Tiere wurden zur Gewinnung der Gesamtblutmenge betäubt und ausgeblutet. Das gewonnene Serum wurde fraktioniert und nach Einfrieren in flüssigem Stickstoff bei $-20^{\circ} \mathrm{C}$ gelagert.

\subsection{Reinigung von Antikörpern}

Zur Aufreinigung von IgG-Antikörpern aus Kaninchen-Serum wurde eine Methode angewendet, bei welcher E. coli-Proteine kovalent an eine Säule gebunden und danach E.coli spezifische Antikörper aus appliziertem Serum entfernt und IgGs aufgereinigt wurden. IgGFraktionen von Kaninchen binden an Protein A Sepharose über die Fc-Region, wohingegen andere Proteine im Serum nicht binden. Die Bindung der IgGs an Protein Sepharose A wird bei der Elution mit 0,1 M Glycin, pH 3,0 gelöst, sodass gereinigte IgGs erhalten werden.

Im Einzelnen erfolgte die Aufreinigung von Wind-Antikörpern folgendermassen: 1 L Bakterienkultur (XL1Blue) wurde bis zum Erreichen der stationären Phase über Nacht bei $37^{\circ} \mathrm{C}$ anwachsen gelassen. Nach Ernten der Zellen durch Zentrifugation (4000 g, $20 \mathrm{~min}, 4^{\circ} \mathrm{C}$ ) und Entfernen der Medienreste wurden die Zellen in $100 \mathrm{ml}$ Lysepuffer resuspendiert. Nach 
Zugabe von $2 \mathrm{mg} / \mathrm{ml}$ Lysozym (AppliChem) erfolgte eine Inkubation bei Raumtemperatur für 20 min. Zur weiteren Lösung sowie Degradation von DNA wurden

0,2 \% (w/v) Triton-X-100 und $10 \mu \mathrm{g} / \mathrm{ml}$ pankreatische DNaseI hinzugegeben. Nach Inkubation dieser Suspension für $1 \mathrm{~h}$ bei $4^{\circ} \mathrm{C}$ wurde das bakterielle Lysat bei $8000 \mathrm{~g}, 20 \mathrm{~min}$, $4^{\circ} \mathrm{C}$ abzentrifugiert. Der Überstand wurde vorsichtig abgenommen und mit $1 \mathrm{M} \mathrm{NaOH}$ auf einen $\mathrm{pH}-$ Wert von 9 eingestellt. Anschliessend erfolgte die Proteinmessung mit der Bradford-Methode (s. 5.2.1.).

CNBr-Sepharose wurde nach Angaben des Herstellers vorbereitet. 2-3 ml E. coli Lysat wurden pro $1 \mathrm{ml}$ sedimentierter $\mathrm{CNBr}$ gekoppelt. Dieses geschah durch Rotieren bei $4^{\circ} \mathrm{C}$ über Nacht, um eine adäquate Bindung des Antigens an die CNBr-Sepharose (Amersham Pharmacia) zu gewährleisten. Anschliessend folgte das Blocken des Antigens für $2 \mathrm{~h}$ mit 0,1 M Tris-HCl, $\mathrm{pH} \mathrm{8,0} \mathrm{und} \mathrm{mehrere} \mathrm{Waschschritte} \mathrm{mit} \mathrm{je} 5 \mathrm{ml} \mathrm{pH} \mathrm{4,0-Puffer} \mathrm{und} \mathrm{pH} 8,0-$ Puffer im Wechsel. Nach Zugabe von ca. $200 \mu \mathrm{g}$ Serum-Protein wurde erneut über Nacht zur Bindung von Antikörpern an E. coli-Antigene bei $4^{\circ} \mathrm{C}$ inkubiert.

Anschliessend wurde das gebundene Protein auf eine mit PBS äquilibrierte Säule gegeben und mit PBS zur Entfernung unspezifischer Antikörper mit 20 Säulen-Volumina gewaschen. Die Elution der Antikörper erfolgte mit 0,1 M Glycin, $\mathrm{pH} 3,0$ bei $4^{\circ} \mathrm{C}$ in vorbereitete Eppendorf-Gefässe mit vorgelegten 1/10 Vol 1M Tris-HCl, pH 8,3 zur Neutralisation.

Nach Konzentrationsbestimmung wurden die Fraktionen mit der höchsten IgG-Konzentration vereint, aliquotiert, in flüssigem Stickstoff schockgefroren und bei $-80^{\circ} \mathrm{C}$ gelagert.

Verwendete Puffer: Zell-Lysispuffer: $\quad$ 0,1 M Natriumborat, $\mathrm{pH} 8,0$

\begin{tabular}{cl} 
& \multicolumn{1}{c}{$1 \mathrm{M} \mathrm{NaCl}$} \\
& sterilfiltriert, Raumtemperatur \\
& \\
pH 4,0-Puffer: & $0,1 \mathrm{M} \mathrm{Natriumacetat}$ \\
& $0,5 \mathrm{M} \mathrm{NaCl}$ \\
& \\
pH 8,0-Puffer: & $0,1 \mathrm{M} \mathrm{Tris-HCl}$ \\
& $0,5 \mathrm{M} \mathrm{NaCl}$ \\
Elutionspuffer: & $0,1 \mathrm{M} \mathrm{Glycin}, \mathrm{pH} 3,0$
\end{tabular}




\subsubsection{Protein-Quantifizierung nach Bradford (1976)}

Protein-Konzentrationen wurden nach der Bradford-Methode (Bradford, 1976) bestimmt. Der Farbstoff Coomassie Brilliant Blau G250 reagiert mit basischen Aminosäuren. Dabei verschiebt sich das Absorptionsmaximum von $465 \mathrm{~nm}$ zu $595 \mathrm{~nm}$. Zur Ermittlung der Protein-Konzentration wird die Extinktionsänderung bei $595 \mathrm{~nm}$ gemessen.

Um den Proteingehalt einer Probe bestimmen zu können, ist es notwendig, mit Hilfe verschiedener bekannter Proteinmengen eine Eichkurve $\mathrm{zu}$ erstellen. Aus dieser Eichkurve können dann die Proteinkonzentrationen abgelesen oder berechnet werden. Als Standard für die Eichung der Absorption wird eine Lösung aus Rinderserum-Albumin (BSA) mit einer Konzentration von $1 \mathrm{mg} / \mathrm{ml}$ verwendet.

\section{Bradford-Lösung: $\quad 100 \mathrm{mg}$ Coomassie Brilliant Blue G250}

$$
50 \mathrm{ml} 95 \% \text { Ethanol }
$$

$100 \mathrm{ml} 85 \%$ (v/v) Phosphorsäure

ad $1 \mathrm{~L}$ mit $A$. bidest, Lösung filtriert

Der Farbstoff wurde in Ethanol gelöst, anschliessend wurden die verbleibenden Komponenten zugesetzt. Zur Konzentrationsbestimmung wurden $2 \mu 1$ des Proteins in $1 \mathrm{ml}$ Bradford-Lösung pipettiert.

\subsection{Klonierungen}

\subsection{1. cDNA-Klonierung von ERp28}

ERp28-cDNA der Maus wurde unter der Verwendung des RT-PCR-Kits (Quiagen) amplifiziert (Polymerase Kettenreaktion, Mullis, 1986). Als template diente aus Maus F9Zellen extrahierte RNA. Mit Hilfe dieses Konstrukts sollte überprüft werden, ob ERp28 als $D$. melanogaster Wind-Homolog in der Lage ist, Pipe zu prozessieren.

Die Primer wurden von der Datenbank-Sequenz (Eintrag: ak008991) folgendermassen definiert: Erp28for 5'acgtacaagcttgccaccatggccgccgecgecgg, ERp28rev 5'acgtacctgcagcagctcctcettctcagcctc. Diese Primer enthielten 6 variable, überhängende Basen sowie die Erkennungssequenzen für die Restriktionsenzyme HindIII und XhoI zur Einklonierung in den späteren Expressionsvektor pEGFP-N1 (Clontech). Desweiteren wurde 
eine Kozak-Sequenz (Kozak et al., 1987a) für verstärkte Expression in Säuger-Zellen (gccacc) unmittelbar vor das Start-Codon eingesetzt.

Folgender PCR-Mix wurde angesetzt:

$10 \mu 1$ 5x Quiagen OneStep RT-PCR-Puffer (mit 12,5 mM MgCl 2 )

$2 \mu \mathrm{dNTP}(10 \mathrm{mM})$

$0,3 \mu 1$ Primer ERpfor (100 pmol/ $\mu 1)$

$0,3 \mu 1$ Primer ERprev $(100 \mathrm{pmol} / \mu \mathrm{l})$

$0,2 \mu 1$ RNase-Inhibitor

$2 \mu 1$ Quiagen OneStep-RT-PCR Enzym-Mix

$0,2 \mu 1$ Template-DNA ( $50 \mathrm{ng} / \mu \mathrm{l}$ )

$35 \mu 1$ RNase-freies Wasser

$50 \mu \mathrm{l}$ Gesamtvolumen

Das Temperaturprofil für die RT-PCR war folgendes:

\begin{tabular}{ll}
\hline Reverse Transkription: & $50^{\circ} \mathrm{C}, 30 \mathrm{~min}$ \\
Initiale PCR-Aktivierung: & $95^{\circ} \mathrm{C}, 15 \mathrm{~min}$ \\
Denaturierung: & $94^{\circ} \mathrm{C}, 1 \mathrm{~min}$ \\
Annealing: & $62^{\circ} \mathrm{C}, 1 \mathrm{~min}$ \\
Extension: & $72^{\circ} \mathrm{C}, 90 \mathrm{sec}$
\end{tabular}

Abschliessende Extension: $\quad 72^{\circ} \mathrm{C}, 10 \mathrm{~min}$

\subsubsection{Reamplifikation von D. melanogaster Wind-DNA}

D. melanogaster Windbeutel-cDNA (Datenbank: AF025408) wurde von einem template von Dr. D. Ferrari mit dem Vorwärtsprimer 5'caggaggaattcgaagatgatgcatattttggtg und dem Rückwärtsprimer 5'acgtacggatccactcacagttcctccttttccgg reamplifiziert. Diese Primer enthielten variable Überhänge mit den Restriktionsstellen für EcoRI und BamHI. Über diese Restriktionsstellen konnte Wind in den pEGFP-N1 Vektor der Firma Clontech einkloniert 
werden. Die Amplifikationsprimer von Wind wurden so definiert, dass das in der WindSequenz enthaltene Stop-Codon mit amplifiziert wurde. Durch dieses Stop-Codon konnte gewährleistet werden, dass ausschliesslich Wind translatiert wird und so mit spezifischen Antikörpern nachgewiesen werden konnte. Die Domänenstruktur von Wind ist in Abb. 7 dargestellt.

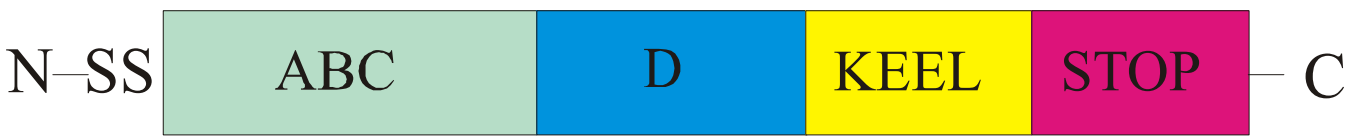

Abb. 7: Schema des Konstruktes full-length Wind. Die Thioredoxin-Domäne ist grün, die D-Domäne blau dargestellt. Das Retentions- /Retrievalsignal ist in gelb gezeigt, das Stop-Codon ist in rot dargestellt. Der N-Terminus verfügt über eine Signalsequenz (ss) .

\subsubsection{Generierung von Punktmutationen in Wind}

Sämtliche Wind-Punktmutationen (s. Tabelle 1) zur Identifizierung einer möglichen Bindungsstelle für Pipe wurden mit dem site-directed-Quick Change-Mutagenesis-Kit von Stratagene mit folgendem Programm generiert:

\begin{tabular}{|c|c|c|}
\hline Denaturierung: & $94^{\circ} \mathrm{C}, \quad 3 \mathrm{~min}$ & \\
\hline Denaturierung: & $94^{\circ} \mathrm{C}, \quad 1 \mathrm{~min}$ & \\
\hline Annealing: & $55^{\circ} \mathrm{C}, 50 \mathrm{sec}$ & 20 Zyklen \\
\hline Extension: & $68^{\circ} \mathrm{C}, 12 \mathrm{~min}$ & \\
\hline Abkühlen: & $4^{\circ} \mathrm{C}$ & \\
\hline
\end{tabular}

Die Primer wurden so definiert, dass die gewünschte Mutation in der Mitte der durchschnittlich 38 bp langen Primer lag, welche mit C oder G endeten. Die Schmelztemperatur dieser Primer lag über $78^{\circ} \mathrm{C}$ und wurde nach folgender Gleichung berechnet:

$\mathrm{T}_{\mathrm{m}}=81,5+0,41$ (\%GC-Gehalt) $-675 / \mathrm{N}-\%$ mismatch

( $\mathrm{N}$ entspricht der Primerlänge in Basen, minimaler GC-Gehalt sollte bei $40 \%$ liegen) 
Der gesamte PCR-Ansatz wurde mit $1,5 \mu \mathrm{DpnI}$ für $1 \mathrm{~h}$ bei $37^{\circ} \mathrm{C}$ verdaut, um parentale, nicht-mutierte DNA und Tochter-DNA zu trennen, die die gewünschte Mutation beinhalten sollte. Der gesamte DpnI-Ansatz wurde - wie in 5.6.4. - beschrieben transformiert.

Tabelle 1: Auflistung aller Punktmutationen. Triplets verändert durch Mutagenese sind kursiv dargestellt.

\begin{tabular}{|c|c|}
\hline Mutation & Vorwärts-Primer 5' \\
\hline $\mathrm{T} 23 \mathrm{~K}$ & ccaccacctgggccgtc $a a$ atgcacgggctgcgtggatc \\
\hline C24S & ccaccacctgggccgtcacctctacgggctgcgtggatctag \\
\hline $\mathrm{T} 25 \mathrm{~K}$ & ctgggccgtcacctgcaagggctgcgtggatctgg \\
\hline G26C & ctgggccgtcacctctacgtgctctgtggatctggatg \\
\hline $\mathrm{C} 27 \mathrm{~S}$ & gtcacctctacgggctctgtggatctagatgagctgag \\
\hline V28Y & cctgcacgggctgctatgatctggatgagctg \\
\hline V28D & cctgcacgggctgcgatgatctggatgagctg \\
\hline $\mathrm{D} 29 \mathrm{~N}$ & gcacgggctgcgtgaatctggatgagctgag \\
\hline D31C & ggctctgtggatctgtgtgagctgagtttcgag \\
\hline D31N & cgggetgcgtggatctaaatgagctgagtttcgag \\
\hline E32K & gctgcgtggatctggataagctgagtttcgagaag \\
\hline R41S & cgagaagacggtggaatcatttccetactccgtag \\
\hline $\mathrm{D} 50 \mathrm{~N}$ & ctactccgtagtgaaatttaatatcgcatatccgtatg \\
\hline D50A & ctactccgtagtgaaatttgctatcgcatatccgtatgggg \\
\hline D50S & ctactccgtagtgaaattttctatcgcatatccgtatgggg \\
\hline I51S & gtagtgaaatttgat $a g c$ gcatatccgtatggg \\
\hline I51R & gtagtgaaatttgatagggcatatccgtatggg \\
\hline A52S & gtagtgaaatttgatatctcatatccgtatgggg \\
\hline Y53S & cgtagtgaaatttgatatcgcatctccgtatggggaaaagc \\
\hline Y53F & gatatcgcatatccgtttggggaaaagcatgaggcct \\
\hline Y55K & gtgaaatttgatatcgcatatccgaagggggaaaagcatgaggcc \\
\hline Y55F & gatatcgcatatccgtttggggaaaagcatgag \\
\hline Y55S & gatatcgcatatccgtctggggaaaagcatgag \\
\hline G56H & cgcatatccgtatcacgaaaagcatgaggcc \\
\hline E57Q & gatatcgcatatccgtatgggcaaaagcatgaggcctttaccg \\
\hline K58S & gcatatccgtatggggaaagtcatgaggcctttaccg \\
\hline
\end{tabular}


Methoden

\begin{tabular}{|c|c|}
\hline H59Y & catatccgtatggggaaaagtatgaggcctttaccg \\
\hline H59R & gtatggggaaaagcgtgaggectttaccg \\
\hline E60Q & ccgtatggggaaaagcatcaggcctttaccgcettctcc \\
\hline E60A & ccgtatggggaaaagcatgcggcctttaccgcettctcc \\
\hline E60D & ccgtatggggaaaagcatgatgcctttaccgccttctcc \\
\hline E60Y & gtatggggaaaagcattatgcctttaccgcettc \\
\hline T63K & gaaaagcatgaggcctttaaggcettctccaaatctg \\
\hline K84D & gccaccgtgggtgtcgacgactatggagaactg \\
\hline K84N & caccgtgggtgtcaatgactatggagaactg \\
\hline K84Q & caccgtgggtgtccaggactatggagaactg \\
\hline K84S & caccgtgggtgtctcggactatggagaactg \\
\hline D85D & gccaccgtgggtgtcaagaactatggagaactggagaacaag \\
\hline Y86S & cgtgggtgtcaaggactctggagaactggagaac \\
\hline Y86L & cgtgggtgtcaaggacctcggagaactggagaac \\
\hline Y86Q & ccgtgggtgtcaaggaccaaggagaactggagaacaag \\
\hline Y86F & ccgtgggtgtcaaggactttggagaactggagaacaag \\
\hline G87S & gggtgtcaaggactattcagaactggagaacaag \\
\hline E88Q & gggtgtcaaggactatggacaactggagaacaag \\
\hline E88K & gtcaaggactatgga $a a a$ ctggagaacaag \\
\hline E90R & gactatggagaactgaggaacaaggccetgggc \\
\hline E90Q & caaggactatggagaactgcagaacaaggtgag \\
\hline D96N & gcaggccetgggcaaccgttacaaagtc \\
\hline $\mathrm{D} 101 \mathrm{~N}$ & gaccgttacaaagtcaacgacaagaacttc \\
\hline $\mathrm{D} 102 \mathrm{~N}$ & ccgttacaaagtcgacaacaagaacttcccgag \\
\hline K103S & gttacaaagtcgacgacagcaacttcccgagtatcttc \\
\hline P106D & gtcgacgacaagaacttcgacagtatcttcctgttcaag \\
\hline D126N & cttcctagccacgtcaacgtaacgctggac \\
\hline Y143S & caacacacctctgtccatcggtcgtgatggctgcatc \\
\hline G145P & cacacctctgtacatccctcgtgatggetgcatc \\
\hline G145S & caacacacctctgtacatcagtcgtgatggctgcatc \\
\hline G148P & gtacatcggtcgtgatccctgcatcaaagagttc \\
\hline G145P-G148P & cacctctgtacatccctcgtgatccctgcatcaaagag \\
\hline C149S & gtacatcggtcgtgatggcagcatcaaagagttcaac \\
\hline
\end{tabular}




\begin{tabular}{|l|l|}
\hline E226Q & caaggccggcaaggtcacccaggccaagaaggaggagc \\
\hline K229S & ggtcaccgaggccaagcaggaggagctgctgagg \\
\hline E231Q & ggtcaccgaggccaagaaggagcagctgctgaggaaac \\
\hline N237A & gctgctgaggaaactggccatcctggaagtcttc \\
\hline
\end{tabular}

Neben den aufgelisteten Mutationen wurden folgende Doppelmutationen in Wind mit den einzeln genannten Primern durchgeführt: D29N-E90R, E60A-E90R und D31N-R41S.

Desweiteren wurde eine Dreifachmutante D31N-R41S-Y55K generiert.

\subsubsection{Amplifikation von Deletionskonstrukten von Wind}

Um zu untersuchen, welche Domänen oder Teile von Domänen von Wind zum Transport von Pipe benötigt werden, wurden mittels PCR folgende cDNAs amplifiziert, welche für diese Deletionskonstrukte kodieren (s. Abb. 8):

a) WindABCD $\triangle \mathrm{KEEL} *$, einem Konstrukt, welchem das retrieval-Signal KEEL fehlt $(\Delta 4$, AS 1-256, Primer-rev 5' acgtacggatccactcattccggcgetgtcttggtg),

b) Wind mit einer um 25 AS verkürzten D-Domäne WindABCDint.KEEL* ( $\Delta 25$, AS 1-236) mit dem Primer-rev 5' acgtacggatccactcacagctcctccttcttgg),

c) ein Kontrukt, welches für die Thioredoxin-Domäne ABC mit KEEL-Motiv kodierte:

WindABC-KEEL* $(\Delta 116$, AS 1-144) mit dem Primer-rev 5' acgtacggatccactcacagttcctcettggcactgacaaaagcett bzw.

d) ein Konstrukt mit nur der Thioredoxin-Domäne ohne KEEL-Signal: WindABC* $(\Delta 120$, AS1-140) mit dem Primer-rev 5'acgtacggatccactcaactgacaaaagccttcaga.

Für alle genannten Konstrukte wurde wiederum der Vorwärtsprimer, wie in 5.3.2. beschrieben, verwendet. Alle genannten Rückwärtsprimer enthielten wiederum ein StopCodon.

a)

AS 1-137

AS $138-253$

AS 254-256

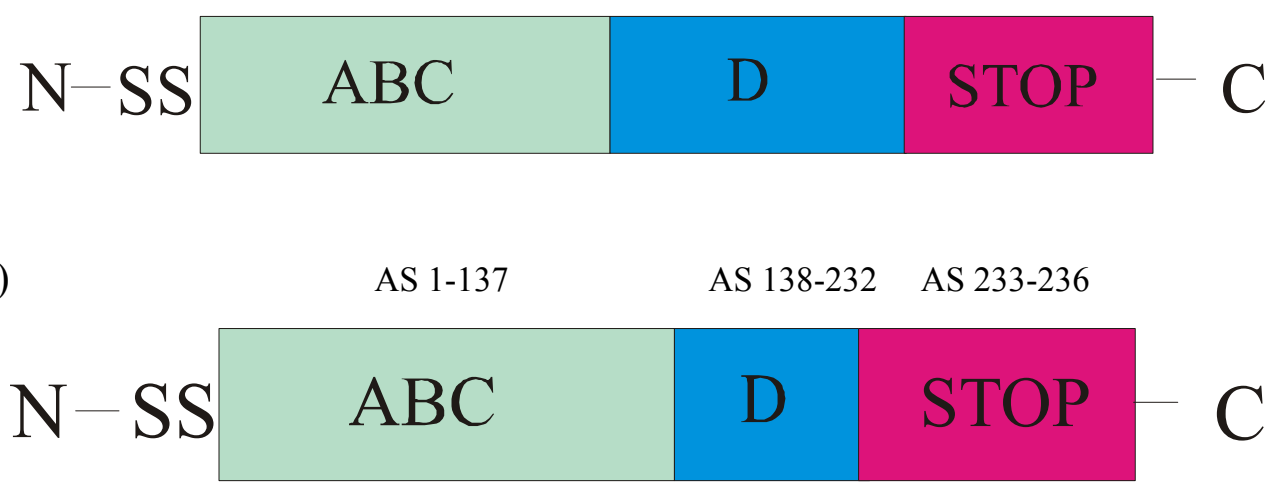


c)

d)

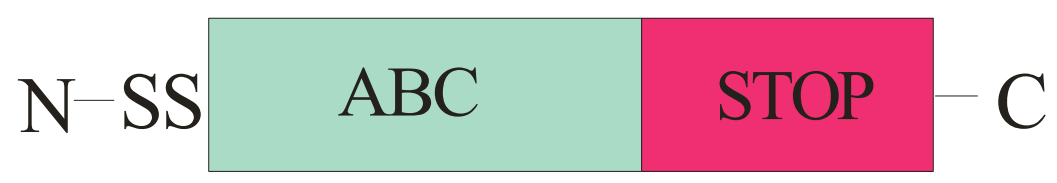

Abb. 8 a-d: Schema der verschiedenen Deletionskonstrukte von Wind.

Farblegende: grün: Thioredoxin-Domäne; blau: D-Domäne; gelb: KEEL-Signal; rot: Stop-Codon. Der N-Terminus verfügt über eine Signalsequenz (ss).

\subsubsection{Weitere Konstrukte: Generierung eines Fusionskonstruktes von Wind mit ERp28}

Ein Fusionskonstrukt, bestehend aus der Thioredoxin-Domäne von Wind (WindABC, Aminosäuren 1-137) und der D-Domäne seines humanen Homologs ERp28 (ERp28-D, Aminosäuren 149-262), wurde kloniert (s. Abb. 9). Mittels dieses Konstruktes sollte überprüft werden, ob die D-Domäne von Wind durch die D-Domäne seines Homologes ERp28 funktionell zu ersetzen ist. Dieses Konstrukt wurde durch Mutation der Aminosäure $\operatorname{Gln}^{150}$ zu Serin in der ERp28 Sequenz (entspricht BamHI-Restriktionsstelle) auf DNA-Ebene generiert. Die D-Domäne von ERp28 wurde mit folgenden Primern amplifiziert: Primer ERpD-for 5' acgtacggatccacggggtctacctgggcatg und ERpD-rev 5' acgtacggatccactcacagctcctccttctcagcct. So konnte die D-Domäne von ERp28 an die Thioredoxin-Domäne von Wind über die BamHI-Restriktionsstelle ligiert werden. Dabei war auf die richtige Orientierung des Inserts zu achten.

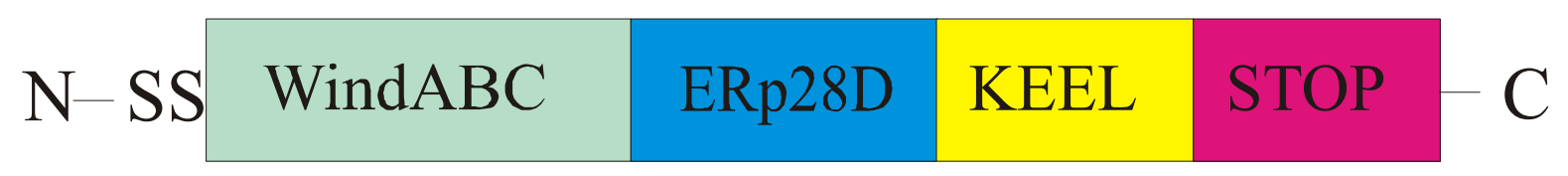

\footnotetext{
Abb. 9: Schema des Fusionskonstruktes bestehend aus der Thioredoxin-Domäne von Wind und der DDomäne von ERp28 (WindABC-ERp28D).

Die Thioredoxin-Domäne von Wind ist grün dargestellt, die D-Domäne von ERp28 ist in blau gezeigt. In gelb ist das KEEL-Signal, in rot das Stop-Codon zu sehen.

Am N-Terminus dieses Fusionskonstruktes ist wiederum eine Signalsequenz (ss) vorhanden.
} 


\subsubsection{Generierung eines ssD-Konstruktes von Wind}

Mit der annealing oligo-Methode (s. 5.3.4.2.1.) wurde ein Konstrukt geschaffen, das die Signalsequenz von Wind in frame an den N-Terminus der D-Domäne von Wind fusionierte (Abb. 10 b). Dieses Konstrukt (Wind ssD*) sollte der Überprüfung dienen, ob die D-Domäne allein in der Lage ist, Pipe zu transportieren.

Zuerst wurde die D-Domäne von Wind mit den Primern 5' acgtaccegcgggccaacacacctctgta und 5' acgtacggatccactcacagttccttttccgg amplifiziert (AS 138 - 257) und über die Schnittstellen SacII und BamHI in den pEGFP-N1-Vektor kloniert. Um die Signalsequenz anzufügen, wurden folgende Primer verwendet: sswind-for mit folgender Basensequenz 5' tcgatatgatgcatatttggtgactctgctcetggtcgctatccactcgatacccaccactgggeccege und sswind-rev 5' ggggcccaggtggtgggtatcgagtggatagcgaccaggagcagagtcaccaaaatatgcatcata. Diese Primer waren so konstruiert, dass sie jeweils komplementär zueinander einen Doppelstrang ausbilden konnten, der über die vorgegebenen Restriktionsstellen (XhoI und SacII) zusammengefügt werden konnte. Die XhoI-Restriktionsstelle wurde modifiziert, so dass das generierte Konstrukt nicht mehr durch dieses Enzym geschnitten werden konnte (Pfeile in Abb. 10a deuten die Restriktion im Enzym an, in rot der komplementäre annealing-Primer, in blau die modifizierte Base in der ursprünglichen XhoI-Sequenz, unterstrichen sind Basen der Restriktionsstelle).

Schema:

a)

F: $\underline{\text { c }}$ tegatatgatgcatatttggtgactetgetcetggtegctatccactcgataccaccactgggecegc $\downarrow$ gg

$\mathrm{R}:$ gagct $\downarrow$ atactacgtataaaaccactgagacgaggaccagcgataggtgagctatgggtggtggacceggg $\downarrow$ cgcc

b)

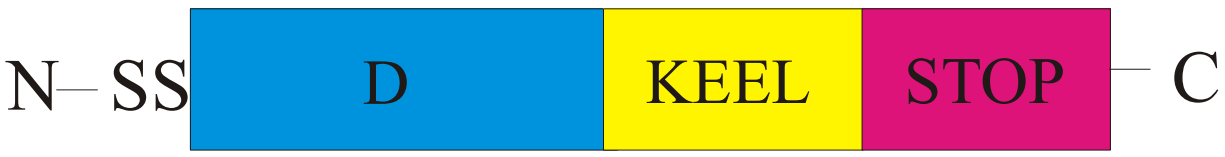

Abb. 10a und b: Schema der gewählten Primer, um das Konstrukt Wind ssD* zu generieren.

In 10a sind die verwendeten Primer gezeigt. In rot ist die Sequenz dargestellt, mit der die Signalsequenz eingefügt wurde. Mit den Pfeilen wird die Stelle der Restriktion in den verwendeten Enzymen XhoI und SacII angezeigt. Die kompletten Restriktionsschnittstellen sind unterstrichen.

In blau ist wiederum die D-Domäne von Wind gezeigt, in gelb das KEEL-Signal, in rot das Stop-Codon. 


\subsection{Annealing oligo-Methode}

Die Oligonukleotide wurden so definiert, dass ein doppelsträngiges Produkt entstand, welches in geschnittene Restriktionsstellen eingefügt werden konnte. Die Oligonukleotide (100 pmol/ $\mu 1)$ wurden je in $50 \mu 1$ sterilem Wasser gelöst. Folgende Reaktion wurde angesetzt: je $10 \mu 1$ von jedem Oligonukleotid wurden mit $24 \mu 12 \mathrm{x}$ annealing-Puffer versetzt $(100 \mathrm{mM}$ Kaliumacetat, $30 \mathrm{mM}$ HEPES-KOH, $2 \mathrm{mM}$ Magnesiumacetat) und wie folgt inkubiert:

\begin{tabular}{|c|}
\hline $4 \min 95^{\circ} \mathrm{C}$ \\
\hline $10 \min 70^{\circ} \mathrm{C}$, \\
\hline Abkühlen auf $4^{\circ} \mathrm{C}$ \\
\hline
\end{tabular}

Im Anschluss daran erfolgte die Phosphorylierung:

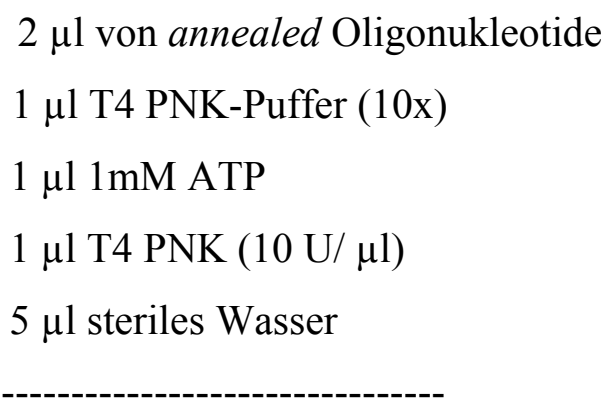

$10 \mu 1$ Gesamtvolumen

Die Phosphorylierung wurde bei $37^{\circ} \mathrm{C}$ für 30 min durchgeführt.

Am Anschluss daran erfolgte die Inaktivierung durch Inkubation von $10 \mathrm{~min}$ bei $70{ }^{\circ} \mathrm{C}$.

Der gesamte Ansatz wurde in das erwünschte Konstrukt einligiert, wie in 5.6 beschrieben.

\subsubsection{Generierung von am N-Terminus von Wind verlängerten Konstrukten}

Weiterhin wurde ein Wind-Konstrukt mit His-tag am N-Terminus kloniert. Der NTerminus von Wind liegt im Dimerspalt. Durch das tag konnte somit der Dimerspalt teilweise ausgefüllt werden. Das Konstrukt sollte der Überprüfung dienen, ob der durch die Homodimerisierung entstandene Dimerspalt für die Pipe-Prozessierung essentiell ist. Als template diente ein His-Wind, kloniert in den pQE30-Vektor von Quiagen (template stammte von Dr. C. Guo). Dieses Konstrukt wurde reamplifiziert (Primer his-for 5' acgtacccgcggatgagaggatcgcatcaccatcaccatcacggatcc sowie Primer his-rev 5' 
acgtacaccggtactcacagttcctccttttccgg) und über SacII und AgeI Restriktionsstellen in den pEGFP-N1-Vektor ligiert.

Wiederum über die annealing oligo-Methode wurde die Signalsequenz von Wind an dieses Konstrukt N-terminal angehängt. Als Primer wurden verwendet:

$5^{\prime}$ tcgatatgatgcatattttggtgactctgctcctggtcgetatccactcgatacccaccacctgggecccgc und rückwärts

$5^{\prime}$ ggggcccaggtggtgggtatcgagtggatagcgaccaggagcagagtcaccaaaatatgcatcata.

In diesem Konstrukt wurde die SacII-Schnittstelle im nachhinein wegmutiert, da das aus Klonierungsgründen eingefügte Prolin an dieser Stelle der Sequenz nicht vorteilhaft ist. Als Mutationsprimer kamen $5^{\prime}$ for cccaccactgggecgagcggatgagaggatcgc und rev $5^{\prime}$ gcgatcctctcatccgetcggcccaggtggtggg zum Einsatz.

Weiterhin wurden zwei verkürzte Konstrukte kloniert: zum einen wurde nur die BamHISchnittstelle aufrechterhalten (a), zum anderen wurden neben der BamHI-Restriktionsstelle noch 2 Histidine eingesetzt (b).

Folgende Primer wurden verwendet: for 5' acgtactcgetattaccatggtgatgc und rückwärts 5' acgtacggatcceggeccaggtggtgggtat bzw. 5' acgtacggatccgtgatgcggeccaggtggtgggtat.

So lagen His-Wind-Konstrukte a) +2 (GS), b) +4 (HHGS) und c) +14 (ERMRGSHHHHHHGS) vor (s. Abb. 11):

a)

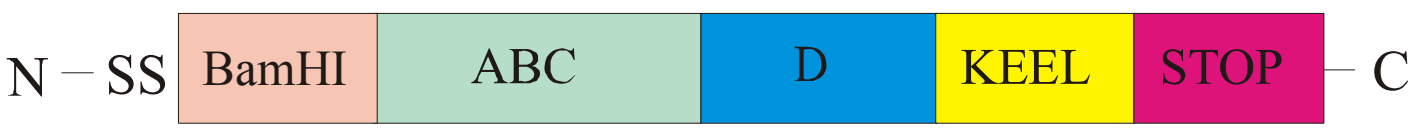

b)

AS 1-137

AS $138-253$

AS 254-257 AS 258-260

\begin{tabular}{l|l|l|l|l|l|l|l|}
\hline $\mathrm{N}-\mathrm{SS}$ & $\mathrm{H}$ & $\mathrm{H}$ & $\mathrm{BamHI}$ & ABC & $\mathrm{D}$ & KEEL & STOP
\end{tabular}

c)

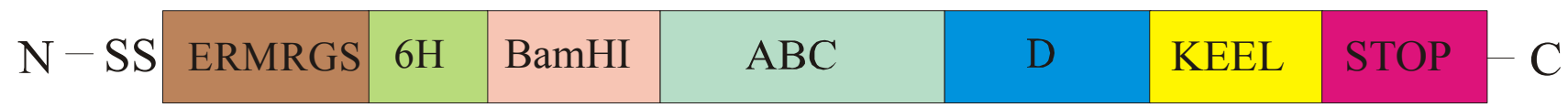

Abb. 11: Schema der Windkonstrukte mit Verlängerungen am N-Terminus.

Die Farbwahl der verschiedenen Domänen dieser Konstrukte entspricht den bereits erwähnten Konstrukten. In allen Konstrukten ist eine BamHI-Schnittstelle (rosa) eingefügt. Das Konstrukt +4 verfügt über 2 Histidine (b), das Konstrukt +14 über 6 Histidine (jeweils grün dargestellt, Abb. 11c). +14 weist zusätzlich 6 Aminosäuren auf (braun), die sich aus der Klonierung im pQE30-Vektor ergeben haben. 


\subsubsection{Klonierung von Pipe}

Aufgrund von Schwierigkeiten bei der Klonierung von full length D. melanogaster Pipe (Datenbank: AF102136) wurde Pipe zunächst in verschiedenen Fragmenten amplifiziert (s. Abb. 12). Ausgehend von einem Klon (RE11403, ResGen) und den Primern 5'pipe-for acgtacctcgaggccaccatgaaactgcgcgatgtggaaa und 5'pipe-rev acgtacgaattcaattgccaatcaggecggg konnten 2 Teilbereiche der Pipe-Sequenz kloniert werden: Fragment 1 entsprechend den ersten 299 bp des 5' Endes von Pipe sowie ein EcoRI-BamHI-Bereich am 3' Ende (Fragment 4, 908-1209 bp). Beide Fragmente wurden je in den pBS Bluescript (Stratagene) einkloniert (Fragment 1 über BstXI und XbaI, Fragment 2 über XbaI und HindIII).

Ein weiterer Teil der Pipe-Sequenz konnte von genomischer DNA (OregonR-Fliegen, erhalten von Dr. M. Takamori) amplifiziert werden (Fragment 2, 544 bp lang, 300-843 bp in der Sequenz). Um dieses mit dem ersten Fragment zu vereinen, war eine überlappende-PCR notwendig. Dazu wurde folgender Ansatz pipettiert:

PCR-1:

PCR-2:

$\begin{array}{llll}\text { Primer pipe-for } & 1 \mu \mathrm{l} & \text { Primer pipe-Fragment } 2 & 1 \mu \mathrm{l} \\ \text { Primer p 315-überlappend } & 1 \mu \mathrm{l} & \text { Primer p 315-überlappend } & 1 \mu \mathrm{l} \\ \text { DNA (Fragment 1) } & 1 \mu \mathrm{l}(20 \mathrm{ng}) & \text { DNA (Fragment 2) } & 1 \mu \mathrm{l}(20 \mathrm{ng}) \\ 10 \mathrm{x} \text { Taq-Puffer } & 5 \mu \mathrm{l} & 10 \mathrm{x} \text { Taq-Puffer } & 5 \mu \mathrm{l} \\ 20 \mathrm{mM} \text { dNTPs } & 1 \mu \mathrm{l} & 20 \mathrm{mM} \text { dNTPs } & 1 \mu \mathrm{l} \\ \text { Taq-Polymerase } & 1 \mu \mathrm{l} & \text { Taq-Polymerase } & 1 \mu \mathrm{l} \\ \text { Wasser } & 40 \mu \mathrm{l} & \text { Wasser } & 40 \mu \mathrm{l}\end{array}$

Gesamtvolumen je $50 \mu 1$ 
In einer dritten PCR-Reaktion wurden beide Fragmente mit den überlappenden Bereichen neu amplifiziert:

PCR-3:

$\begin{array}{lr}\text { Primer pipe-for }(100 \mathrm{pmol} / \mu \mathrm{l}) & 1 \mu \mathrm{l} \\ \text { Primer pipe-Fragment 2 }(100 \mathrm{pmol} / \mu \mathrm{l}) & 1 \mu \mathrm{l} \\ \text { Primer p 315-überlappend }(100 \mathrm{pmol} / \mu \mathrm{l}) & 1 \mu \mathrm{l} \\ 10 \mathrm{x} \text { Taq-Puffer } & 5 \mu \mathrm{l} \\ \text { DNA Fragment } 1(20 \mathrm{ng}) & 1 \mu \mathrm{l} \\ \text { DNA Fragment 2 }(20 \mathrm{ng}) & 1 \mu \mathrm{l} \\ 20 \mathrm{mM} \text { dNTPs } & 1 \mu \mathrm{l} \\ \text { Taq-Polymerase }(5 \mathrm{U} / \mu \mathrm{l}) & 1 \mu \mathrm{l} \\ \text { Wasser } & 38 \mu \mathrm{l}\end{array}$

$50 \mu 1$ Gesamtvolumen

Für alle 3 Reaktionen wurden 30 Zyklen mit folgendem Temperaturprofil durchgeführt:

\begin{tabular}{|ll|}
\hline Denaturierung & $94^{\circ} \mathrm{C}, 4 \mathrm{~min}$ \\
Denaturierung & $94^{\circ} \mathrm{C}, 1 \mathrm{~min}$ \\
Annealing & $53^{\circ} \mathrm{C}, 40 \mathrm{sec}$ \\
Extension & $72^{\circ} \mathrm{C}, 30 \mathrm{sec}$ \\
Extension & $72^{\circ} \mathrm{C}, 10 \mathrm{~min}$ \\
\hline
\end{tabular}

Das auf diese Weise erhaltene PCR-Produkt, bestehend aus den Pipe-Fragmenten 1 und 2, wurde ebenso in den Bluescript-Vektor einkloniert (BstXI/ HindIII)

Der pipe-Fragment 2-Primer enthielt folgende Sequenz: 5' aagggtgtgcattcgtagtcgtgaccgcag aagaataagc. Der überlappende Primer p315 wurde folgendermassen definiert: Primer überlappend 5 ' gttcagatccegcacgttaagagaggacatctggccagtgctcttcag.

Die noch vorhandene Lücke in der Sequenz von 844-907 bp wurde mit Hilfe der annealing oligo-Methode aufgefüllt. Die fehlenden 64 bp wurden als Megaprimer bei MWG chemisch so synthetisiert, dass sie über die vorhandene $B s m I$-Schnittstelle und eine extra zu Klonierungszwecken eingeführte MluI-Schnittstelle überlappend eingefügt werden konnten: 
$5^{\prime}$ for-oligo caccettcaacacagtgggtgccctcgagcgagccaagtttgccgtagaacaacagta und 5 'rev-oligo cgcgtactgttgttctacggcaaacttggctcgctcgagggcacccactgtgttgaagggtgtg.

Die MluI-site wurde anschliessend entsprechend des Mutagenese-Protokolls zurückmutiert ( 5.3.3.). Über die Restriktionsstellen KnpI und BamHI wurde Pipe in den pEGFP-N1-Vektor von Clontech ligiert. Somit ergab sich ein Translokations-kompetentes, full-length Protein, welches an den N-Terminus von GFP fusioniert war.

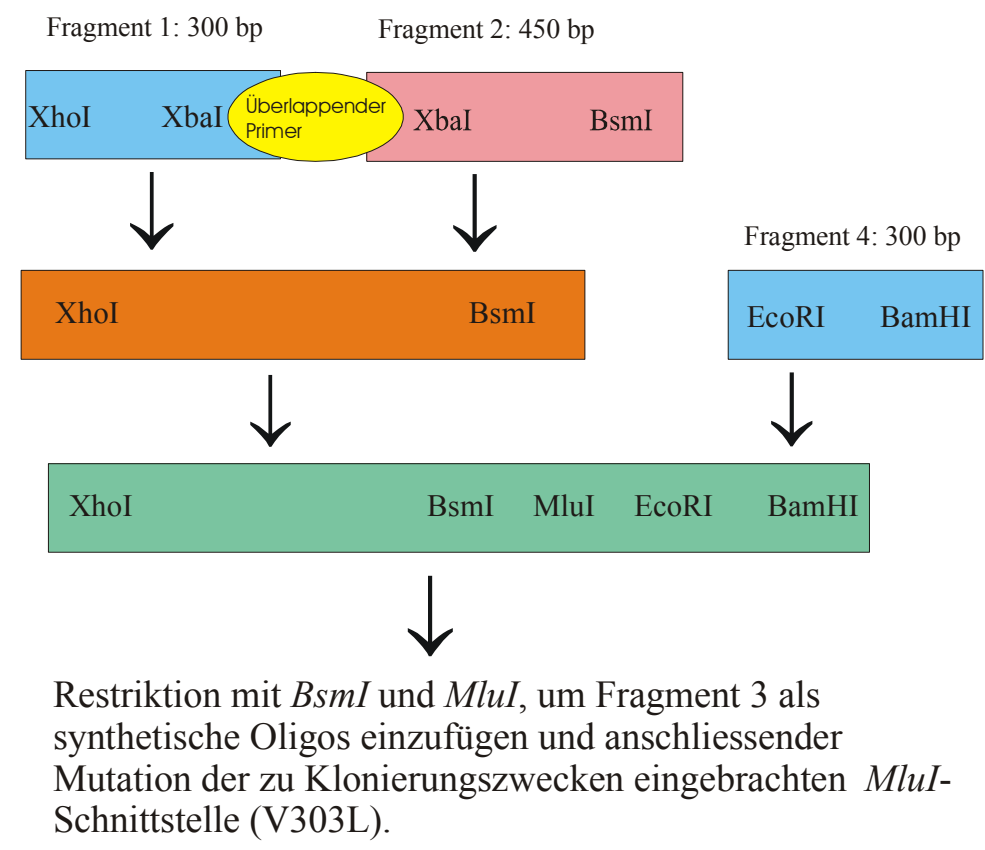

Abb. 12: Schema der Klonierungsschritte zur Gewinnung von full-length Pipe. Erläuterung siehe Text.

\subsubsection{Generierung eines Pipe-Myc Konstruktes}

Eine cDNA, die für Pipe mit einem C-terminalen Myc-Tag codierte, wurde wie folgt amplifiziert: als Primer wurden hierfür verwendet: Primer Pipe-myc-for 5' atagtagaattcgccaccatgaaactgcgcgatgtg sowie Primer Pipe-myc-rev 5'

ttaaataagcttattgccaatcaggccgggcag. Diese wiesen Schnittstellen für EcoRI und BamHI auf.

Das amplifizierte PCR-Produkt wurde in die multiple cloning site des Vektors pCMV von Clontech über die Restriktionsstellen EcoRI und HindIII einkloniert.

Dieses Konstrukt sollte der Überprüfung dienen, ob die Oligomerisierung von Pipe GFPabhängig ist. 
5.3.5.2. Generierung eines Konstruktes der löslichen Domäne von Pipe sowie $\underline{\text { Deletionskonstrukte der löslichen Domäne }}$

Es wurden mehrere Fusionskonstrukte von Pipe mit GFP hergestellt, um zu untersuchen, auf welche Weise Pipe in Abwesenheit von Wind im ER reteniert wird. So z.B ein Konstrukt, welches für die lösliche, intraluminale Sequenz von Pipe ohne die Transmembrandomäne codiert (Abb. 13a). Folgende Primer wurden hierzu verwendet: Primer Pipefor 5' acgtacggatcccacaccaacaaactgaacagtcg und Pipe-rev 5' acgtacaccggtacattgccaatcaggccggg. Dieses amplifizierte Konstrukt wurde in das mit BamHI und AgeI geschnittene Plasmid His-Wind + 2 im pEGFP-N1-Vektor über die Restriktionsstellen BamHI und AgeI so einkloniert, dass das exprimierte Protein über eine N-terminale Signalsequenz verfügte (a).

Mit diesem Konstrukt sollte festgestellt werden, ob Pipe in Abwesenheit von Wind im ER aggregiert.

Darüber hinaus wurde die lösliche Domäne von Pipe vom C-Terminus her unter Verwendung folgender Primer verkürzt (Abb. 13 b, c): b) TM202 AS ( $\Delta 201$ AS) der Primer 5' rev acgtacggatccacatcgcggaccacatttaggta sowie für c) TM252 AS ( $\Delta 151$ AS) der Primer 5' rev acgtacggatccacctcctgatcgccattaagg.

a)

AS $39-403$

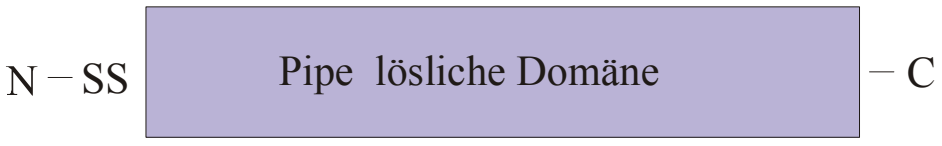

b)

AS $1-38 \quad 39-202$

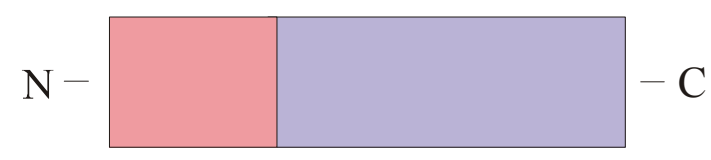

c)

AS $1-38 \quad 39-252$

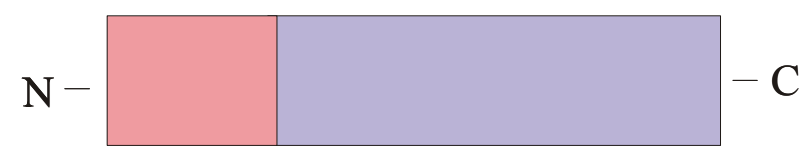

Abb. 13: Schema des Konstrukts der löslichen Domäne allein (a) sowie der verkürzten löslichen Domäne von Pipe (b, c). In rosa ist die Transmembran-Domäne, in violett die lösliche Domäne dargestellt. 


\subsubsection{Generierung von Transmembran-Konstrukten von Pipe}

Ausgehend vom Pipe-WT wurden Transmembran-Konstrukte amplifiziert (Abb. 14). Mit diesen Konstrukten sollte die Lokalisation von Pipe überprüft werden. Für sämtliche PCR-Reaktionen wurde der Primer Pipe-for 5' acgtacgaattcgccaccatgaaactgcgcgatgtggaaa verwendet. Um die ersten 50 Aminosäuren ( $\triangle 353 \mathrm{AS})$ der Transmembranregion von Pipe zu amplifizieren (TM50), wurde der Primer Pipe-50-rev definiert: 5' acgtacggatccaccatctccttgaggcgactgt. Entsprechend wurde für die ersten 95 Aminosäuren ( $\Delta 308$ AS) der Transmembranregion der Primer 5' acgtacggatccacctggccagtgctcttcag verwendet (TM95).

a)

AS $1-38 \quad 39-50$

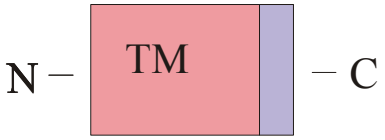

b)

AS 1-38 39- 95

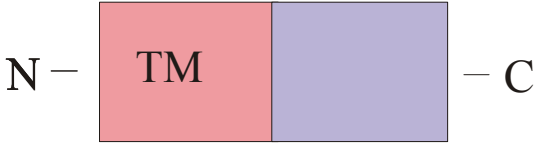

Abb. 14: Schema der verschiedenen Transmembrankonstrukte von Pipe. In rosa ist die TransmembranRegion, in violett sind Teile der löslichen Domäne dargestellt.

\subsubsection{Mutation im pEGFP-Vektor}

Um Spontanassoziationen von GFP-Molekülen zu reduzieren, wurde im pEGFPVektor die Mutation A206K eingefügt (Zacharias et al., 2002). Dazu wurde folgender pEGFP-Mutationsprimer definiert: 5' for cactacctgagcacccagtccaagctgagcaaagaccccaacgag. Der Rückwärtsprimer ist entsprechend komplementär zum genannten Primer.

\subsection{Untersuchung von DNA durch Agarosegelelektrophorese}

Zur Analyse von Plasmid-DNA-Präparationen und DNA-Produkten aus PCR- oder Verdau-Reaktionen wurden 1 bis 2 \%ige Agarosegele eingesetzt. Die Wahl der AgaroseKonzentration war dabei abhängig von der DNA-Grösse (DNA-Fragmente mit einer Grösse 
unter $0,5 \mathrm{~kb}$ wurden auf $2 \%$-igen Gelen aufgetrennt). Die entsprechende Menge Agarose wurde in einem Becherglas in $100 \mathrm{ml}$ 1x TBE-Puffer (Tris-Borat-EDTA) suspendiert und durch Aufkochen in einer Mikrowelle gelöst. Nach Abkühlen auf ca. $60{ }^{\circ} \mathrm{C}$ wurde die Lösung in einen Gelträger mit 2 Kämmen gegossen (Grösse ca. 10 x $10 \mathrm{~cm}$ ) und ausgehärtet.

Nach Einsetzen des Gelträgers in eine horizontale Gelkammer, Überschichten des Gels mit 1 x TBE-Puffer und Herausziehen der Kämme wurden die DNA-Proben mit 6 x Probenpuffer versetzt und in die Geltaschen pipettiert.

Zur Grössenbestimmung wurden $4 \mu \mathrm{l}$ DNA-Marker mit geeignetem Grössenbereich aufgetragen. Die Elektrophorese wurde $1 \mathrm{~h}$ bei $85 \mathrm{~V}$ durchgeführt. Anschliessend wurde das Gel für 15 min in einem Ethidiumbromid-Bad (1 $\mu \mathrm{g} / \mathrm{ml}$, Sigma) zum Anfärben der DNABanden inkubiert und die DNA-Banden anschliessend auf einem UV-Durchlichttisch (Biometra) bei einer Wellenlänge von $302 \mathrm{~nm}$ sichtbar gemacht. Die Gel-Dokumentation erfolgte mittels einer Computer-gesteuerten CCD-Kamera.

10 x TBE-Puffer: $500 \mathrm{mM}$ Tris

$10 \mathrm{mM}$ EDTA $500 \mathrm{mM} \mathrm{H}_{3} \mathrm{BO}_{3}, \mathrm{pH} 8,1$

\subsection{Aufreinigung von DNA aus Agarosegelen und DNA-Konzentrationsbestimmung}

Zur Aufreinigung wurden die gewünschten DNA-Banden unter UV-Licht mit einem sterilen Skalpell ausgeschnitten, in ein steriles Eppendorf-Gefäss gegeben und nach Angaben des Herstellers mit dem NucleoSpin Extraktions-Kit (Macherey und Nagel) gereinigt.

Die Quantifizierung der DNA erfolgte photometrisch mit dem GeneQuant II-Photometer von Pharmacia. Dabei entspricht eine OD 260 von 1.0 einer Konzentration von $50 \mu \mathrm{g} / \mathrm{ml}$ ds-DNA.

\subsection{Restriktionsanalyse, Dephosphorylierung und Ligation}

Restriktionsanalysen wurden so durchgeführt, dass das Gesamtvolumen der zugegebenen Restriktionsenzyme nicht mehr als $10 \%$ betrug, da es anderenfalls zu einer Hemmung des Verdaus durch den Glycerin-Anteil der Enzympräparation kommt. Restriktionsansätze wurden entweder durch Gelelektrophorese (s. 5.5) oder mit dem PCRPurifikations-Kit von Macherey \& Nagel gereinigt.

Um mögliche unerwünschte Religationen von Plasmid-DNA zu verhindern, wurde das 
5'-Ende der DNA mit Alkalischer Phosphatase (Roche, 1 U/ $\mu$ g DNA) aus Krabben für $30 \mathrm{~min}$ bei $37^{\circ} \mathrm{C}$ dephosphoryliert. Anschliessend erfolgte die Inaktivierung der Phosphatase durch Inkubation bei $65^{\circ} \mathrm{C}$ für $10 \mathrm{~min}$ und die Aufreinigung der DNA mit dem Macherey \& Nagel-Kit.

Zur Ligation von sticky end-DNA in den pEGFP-N1-Vektor wurde die T4-DNA-Ligase verwendet. Die Ligationsreaktion wurde 2-6 h bei Raumtemperatur bei einem molaren Verhältnis von Insert : Vektor von $1: 1$ bis $5: 1$ durchgeführt. Die durchschnittliche Vektormenge betrug dabei $50 \mathrm{ng}$.

Der Ansatz wurde wie folgt pipettiert:

ca. $50-500$ ng Insert

50 ng Vektor

$1 \mu \mathrm{l}$ Ligasepuffer (10x, mit ATP)

0,5 - 1 U T4-DNA-Ligase (30 Weiss-Units/ $\mu \mathrm{l}$ )

ad $10 \mu 1$ mit $A$. bidest

\subsection{Transformation von E. coli}

\subsubsection{Herstellung elektrokompetenter E. coli-Zellen}

Zur Herstellung von elektrokompetenten E. coli-Bakterien wurde von einem gefrorenen Stamm XL1Blue etwas Material in einer LB-Übernachtkultur $\left(100 \mathrm{ml}, 37^{\circ} \mathrm{C}\right.$, $200 \mathrm{rpm}$ ) mit 12,5 $\mu \mathrm{g} / \mathrm{ml}$ Tetracyclin vermehrt. $10 \mathrm{ml}$ davon wurden in $1 \mathrm{~L}$ frisches LBMedium überführt. Die Kultur wurde unter weiterem Schütteln bei $37^{\circ} \mathrm{C}$ bis zu einer $\mathrm{OD} 600$ von 0,5 - 0,7 wachsen gelassen. Nach kurzem Abkühlen der Bakterienkultur auf Eis wurden die Zellen durch Zentrifugation ( $\left.4000 \mathrm{~g}, 4^{\circ} \mathrm{C}, 20 \mathrm{~min}\right)$ geerntet.

Nach Entfernung des Medien-Überstandes wurden die Bakterien in 1 L eiskaltem, sterilem HEPES-Puffer resuspendiert. Es folgte eine weitere Zentrifugation bei $4000 \mathrm{~g}\left(20 \mathrm{~min}, 4{ }^{\circ} \mathrm{C}\right)$, und das Sediment wurde in $500 \mathrm{ml}$ HEPES-Puffer suspendiert. Die Zentrifugation wurde wiederholt und die sedimentierten Bakterien in $2 \mathrm{ml} 10 \%$ (v/v) Glycerol-Lösung aufgenommen. 
Gebrauchsfertige Aliquots $(50-200 \mu 1)$ wurden in sterile Eppendorf-Gefässe pipettiert, in flüssigem Stickstoff schockgefroren und bei $-80^{\circ} \mathrm{C}$ gelagert.

\section{Verwendete Puffer:}

HEPES-Puffer: $\quad 1 \mathrm{mM}$ HEPES, $\mathrm{pH} 7,0$, autoklaviert

$10 \%$ Glycerol: $10 \%$ (v/v) Glycerol in A. bidest, autoklaviert

\subsubsection{Herstellung chemisch-kompetenter E. coli-Zellen}

Zur Herstellung von chemisch-kompetenten E. coli-Bakterien war ebenso eine Übernachtkultur (DH5a-Zellen oder XL1Blue) notwendig. Es wurden von dieser Übernachtkultur $4 \mathrm{ml}$ in $400 \mathrm{ml}$ frisches LB-Medium inokuliert und bis zum Erreichen einer OD 600 von 0,4 unter Schütteln bei $37^{\circ} \mathrm{C}$ wachsen gelassen. Die Zellen wurden kurz auf Eis abgekühlt und durch Zentrifugation geerntet $\left(4000 \mathrm{~g}, 4^{\circ} \mathrm{C}, 20 \mathrm{~min}\right)$. Anschliessend wurden die Zellen in $50 \mathrm{ml}$ eiskaltem, sterilem $\mathrm{CaCl}_{2}$-Puffer resuspendiert.

Dieser Zentrifugations- und Resuspendierungsvorgang wurde wiederholt, bevor eine Inkubation für 30 min auf Eis erfolgte. Anschliessend wurde erneut zentrifugiert, und die Zellen wurden je nach Pelletgrösse in $3-5 \mathrm{ml}$ des $\mathrm{CaCl}_{2}$-Puffers resuspendiert, zu 50 $200 \mu 1$ aliquotiert und in flüssigem Stickstoff schockgefroren. Die Lagerung erfolgte bei $-80^{\circ} \mathrm{C}$.

\section{$\underline{\mathrm{CaCl}}_{2}=-$ Puffer:}

$60 \mathrm{mM} \mathrm{CaCl}_{2}$

$15 \%$ (v/v) Glycerol

$10 \mathrm{mM}$ PIPES

ad $1 \mathrm{~L}, \mathrm{pH}$ 7,0, autoklaviert 


\subsubsection{Transformation durch Elektroporation}

Zur Transformation von DNA wurden elektrokompetente XL1Blue-Zellen auf Eis aufgetaut. Plasmide (50-100 ng) wurden hinzupipettiert und in vorgekühlte 0,2 cm Elektroporationsküvetten (BioRad) gegeben. Die Elektroporation erfolgte mit den Parametern $25 \mu \mathrm{F}$, 2,5 kV, $200 \Omega$. Nach Anlegen des Pulses konnte eine Zeitkonstante von 4 - 4,5 ms gemessen werden. Es wurde sofort $500 \mu 1 \mathrm{LB}-$ Medium hinzugegeben und die Suspension in ein steriles Eppendorf-Gefäss pipettiert. Die Produktion selektiver Markerproteine in den Zellen erfolgte für $1 \mathrm{~h}$ bei $37^{\circ} \mathrm{C}$ und $450 \mathrm{rpm}$ auf einem Thermoschüttler (Eppendorf). Die anschliessend ausgestrichenen Selektivplatten wurden über Nacht bei $37^{\circ} \mathrm{C}$ inkubiert.

\subsubsection{Transformation durch Hitzeschock}

Nach Auftauen der Aliquots von chemisch kompetenten Bakterien (XL1Blue oder DH5 $\alpha$ ) wurden ca. 50 ng Plasmid, in Fällen von Ligationsreaktionen der gesamte Ligationsansatz hinzupipettiert. Es erfolgte eine Inkubation von $30 \mathrm{~min}$ auf Eis. Der Hitzeschock wurde für DH5 $\alpha$-Zellen bei $42^{\circ} \mathrm{C}$ für $45 \mathrm{sec}$ bzw. bei XL1Blue-Zellen $90 \mathrm{sec}$ im Wasserbad durchgeführt.

Nach raschem Abkühlen auf Eis (2 min) wurden die Zellen mit $500 \mu \mathrm{l}$ LB-Medium versetzt und für $1 \mathrm{~h}$ bei $37^{\circ} \mathrm{C}$ unter $450 \mathrm{rpm}$ inkubiert. Anschliessend erfolgte das Ausplattieren auf Selektivplatten und die Inkubation über Nacht bei $37^{\circ} \mathrm{C}$.

\subsection{DNA-Präparationen}

Unter Verwendung der Kits von Macherey \& Nagel wurde DNA in Mini-, Maxisowie endotoxinfreiem Maxi-Massstab hergestellt. Sämtliche DNA-Präparationen, die in Transfektionsexperimenten zum Einsatz kamen, wurden endotoxinfrei hergestellt, um eine Schädigung der Zellen durch Endotoxine zu verhindern.

Das Prinzip einer endotoxinfreien Präparation umfasst eine alkalische SDS-Lyse. Sowohl chromosomale als auch Plasmid-DNA wurden unter alkalischen Bedingungen denaturiert. Zum denaturierten Lysat wurde Kaliumacetat zum Präzipitieren von chromosomaler DNA und anderen Zellbestandteilen hinzugegeben. Gleichzeitig wurde das Lysat durch das Kaliumacetat neutralisiert. Die Plasmid-DNA blieb dabei in Lösung und konnte so in nativer, supercoiled Form erhalten werden. Nach Equilibrieren einer Säule mit einem Puffer wurde 
DNA an eine Anionen-Austausch-Matrix gebunden. Nach mehrmaligem Waschen wurde die DNA mit Wasser eluiert. Im Einzelnen erfolgte die Präparation nach Herstellervorschrift.

\subsubsection{Sequenzierung von DNA}

Sequenzierungen wurden als Auftragsarbeiten im Max-Planck-Institut in der Abteilung Entwicklungsbiologie durch Herrn G. Dowe auf AbiPrism 377 Sequenzierern oder von der Fa. Seqlab, Göttingen durchgeführt. Dazu wurden folgende Primer verwendet: pEGFP-N1-for 5'caacgggactttccaaaatg und pEGFP-N1-rev 5' gctgaacttgtggecgttt.

Folgende Ansätze waren erforderlich: 300 ng DNA

$$
\begin{aligned}
& 0,3 \text { pmol Primer } \\
& \text { in } 10 \mu \mathrm{l} \text { Wasser }
\end{aligned}
$$$$
\text { für hausinterne Proben für Seqlab, Göttingen }
$$

600 ng DNA

20 pmol Primer

in $7 \mu 1$ Wasser

Seqlab, Göttingen

\subsection{Protein-Gelelektrophorese}

\subsubsection{Denaturierende SDS-Polyacrylamid-Gelelektrophorese nach Laemmli (1970)}

Die SDS-Polyacrylamid-Gelelektrophorese (SDS-PAGE) ermöglicht eine Auftrennung von Proteinen gemäss ihrer Grösse in einem elektrischen Feld in einer vernetzten Polymermatrix.

Als Polymer dient Polyacrylamid, das cross-linking Reagenz ist Bis-Acrylamid.

Ein solches Gel beinhaltet ein oberes Sammelgel, welches niedrigen pH-Wert und geringen Gehalt an cross-linker aufweist und ein gleichmässiges Einlaufen der Proben in das Gel ermöglicht. Im unteren Gel (Trenngel) mit höherem pH-Wert werden die Proben gemäss ihrer Grösse aufgetrennt. Unter den gewählten Bedingungen wandern die Proteine im elektrischen Feld von der Kathode zur Anode.

Zur Denaturierung von Proteinen und Anfügen negativer Ladung, welche proportional zur Grösse ist, wurde den Proteinen 10 \% iges SDS hinzugefügt. Durch Zusatz von DTT konnten vorhandene Disulfidbrücken reduziert werden.

Mini-Gele (7 x $10 \mathrm{~cm})$ wurden in folgender Zusammensetzung hergestellt: 


\begin{tabular}{|l|l|l|l|l|}
\hline Komponente & $\mathbf{5}$ \% Sammelgel & $\mathbf{7 , 5} \%$ Trenngel & $\mathbf{1 0}$ \% Trenngel & $\mathbf{1 2 , 5} \%$ Trenngel \\
\hline Lösung A & --- & $1,5 \mathrm{ml}$ & $1,5 \mathrm{ml}$ & $1,5 \mathrm{ml}$ \\
\hline Lösung B & $625 \mu \mathrm{l}$ & & --- & --- \\
\hline Lösung C & $375 \mu \mathrm{l}$ & $1,5 \mathrm{ml}$ & $2,0 \mathrm{ml}$ & $2,5 \mathrm{ml}$ \\
\hline Wasser & $1,28 \mathrm{ml}$ & $3,0 \mathrm{ml}$ & $2,5 \mathrm{ml}$ & $2,0 \mathrm{ml}$ \\
\hline TEMED & $3 \mu \mathrm{l}$ & $3 \mu \mathrm{l}$ & $3 \mu \mathrm{l}$ & $3 \mu \mathrm{l}$ \\
\hline $40 \%$ APS & $22,5 \mu \mathrm{l}$ & $22,5 \mu \mathrm{l}$ & $22,5 \mu \mathrm{l}$ & $22,5 \mu \mathrm{l}$ \\
\hline $10 \%$ SDS & $25 \mu \mathrm{l}$ & $60 \mu \mathrm{l}$ & $60 \mu \mathrm{l}$ & $60 \mu \mathrm{l}$ \\
\hline
\end{tabular}

Lösung A: 1,5 M Tris/HCl, $\mathrm{pH} 8,9$

Lösung B: 0,5 M Tris/HCl, pH 6,8

Lösung C: 29,2 \% (w/v) Acrylamid $0,8 \%(\mathrm{w} / \mathrm{v})$ Bis-Acrylamid

APS: $\quad 40 \%(w / v)$ Ammoniumpersulfat

SDS: $\quad 10 \%(\mathrm{w} / \mathrm{v})$ Natrium Dodecylsulfat

Probenpuffer nach Laemmli: 62,5 mM Tris/HCl, pH 6,8

$$
\begin{gathered}
3 \%(\mathrm{w} / \mathrm{v}) \text { SDS } \\
10 \%(\mathrm{w} / \mathrm{v}) \text { Glycerol } \\
10 \%(\mathrm{w} / \mathrm{v}) \text { 2-Mercaptoethanol } \\
0,001 \%(\mathrm{w} / \mathrm{v}) \text { Bromphenolblau }
\end{gathered}
$$

1x Laufpuffer: $25 \mathrm{mM}$ Tris

$$
\begin{aligned}
& 0,1 \%(w / v) \text { SDS } \\
& 192 \text { mM Glycin, pH 8,7 }
\end{aligned}
$$

Für das Trenngel wurden die genannten Lösungen gemischt und nach Zusatz von 40 \% APS (Merck) und TEMED (1,2-Bis-(dimethylamino)-Ethan, Sigma) unverzüglich in die Gelapparatur gegossen (bis $2 \mathrm{~cm}$ unter dem oberen Rand). Die Glasplatten wurden zuvor mit $70 \%$ Ethanol gereinigt. Um eine Austrocknung des Gels zu vermeiden, wurde das Trenngel 
sofort mit etwas Wasser-gesättigtem Isopropanol überschichtet. Nach abgeschlossener Polymerisation und Entfernen des Isopropanols wurde das Sammelgel darüber gegossen und ein Plastikkamm eingesetzt. In die Taschen dieses Kammes können 10 Proben pro Gel mit bis zu $30 \mu \mathrm{l}$ Volumen aufgetragen werden. In die Gelapparatur wurde 1 x Laufpuffer gegossen. Die Proben wurden schliesslich mit dem gleichen Volumen 2 x Probenpuffer und 1/5 Volumen DTT versetzt, $5 \mathrm{~min}$ bei $95^{\circ} \mathrm{C}$ denaturiert, nach Entfernen des Kammes in die Taschen pipettiert und bei einer Spannung von $20 \mathrm{~mA}$ pro Gel für $1 \mathrm{~h}$ aufgetrennt, bis die Front des Ladepuffers den unteren Rand des Gels erreicht hat.

\subsection{Anfärben von Proteinen in Polyacrylamid-Gelen}

\subsubsection{Coomassie-brilliant-Blau-Färbung}

Proteingele wurden nach beendeter Elektrophorese in Coomassie-Färbelösung für $1 \mathrm{~h}$ gefärbt. Anschliessend erfolgte die Entfärbung des Gels und in einer weiteren Lösung das Rehydrieren. Für Protokollzwecke wurden die Gele unter Vakuum getrocknet.

Folgende Lösungen wurden verwendet:

\section{Coomassie:}

Coomassie Brilliant Blau R250 0,2\%(w/v)

Ethanol $42,5 \%(\mathrm{v} / \mathrm{v})$

Methanol $5 \%(\mathrm{v} / \mathrm{v})$

Essigsäure $10 \%(\mathrm{v} / \mathrm{v})$

ad $1 \mathrm{~L}$ mit $A$. bidest

\section{Entfärbelösung I:}

Ethanol $\quad 45 \%(\mathrm{v} / \mathrm{v})$

Essigsäure $\quad 10 \%(\mathrm{v} / \mathrm{v})$

ad 1 L mit $A$. bidest 


\section{Entfärbelösung II:}

Essigsäure $\quad 7 \%(\mathrm{v} / \mathrm{v})$ in $1 \mathrm{~L}$ A. bidest

\section{$\underline{\text { 5.11. Western Blot nach Towbin (1979) }}$}

\section{$\underline{\text { 5.11.1. Western Blot auf Nitrocellulose-Membranen }}$}

Nach Beendigung derElektrophorese wurde das Gel auf in Blotpuffer präequilibrierte Whatmann-Papiere (Schleicher \& Schüll, GB005) in einer Blot-Apparatur (Phase, Lübeck) gelegt. Darauf wurde die ebenso präequilibrierte Nitrocellulose-Membran gelegt. Es folgte eine weitere Lage Whatmann-Papier. Mit dieser semi-dry-Methode wurden mittels Spannung von 100 mA/ Stunde Proteine aus dem Gel auf die Membran Richtung Anode transferiert.

\section{L Blot-Puffer:}

$$
\begin{aligned}
& 20 \% \text { (v/v) Methanol } \\
& 25 \text { mM Tris/HCL, pH 8,3 } \\
& 192 \text { mM Glycin }
\end{aligned}
$$

ad $1 \mathrm{~L}$

\subsubsection{Proteinidentifizierung auf Nitrocellulose-Membranen mit Antikörpern}

Transferierte Proteine wurden auf einer Nitrocellulose-Membran (Schleicher \& Schüll) durch kurzzeitige Anfärbung mit Ponceau S-Lösung (Fluka) nachgewiesen. Das Ponceau Rot wurde durch mehrmaliges Waschen mit 1 x PBS entfernt. Im Anschluss daran erfolgte das Blocken für $2 \mathrm{~h}$ bei Raumtemperatur in $5 \%$-iger Milchpulver-PBS-Lösung bzw. übernacht in 0,5 \% Milchpulver-PBS. Der Primärantikörper wurde 1: 1000 in $10 \mathrm{ml}$ Inkubationspuffer $(0,5 \%$ Milchpulver-PBS) verdünnt und die Membran damit $1 \mathrm{~h}$ bei Raumtemperatur inkubiert.

Nach dreimaligem Waschen für je $5 \mathrm{~min}$ in $0,5 \%$ Milchpulver-PBS wurde der Sekundärantikörper in einer Verdünnung von $1: 20000$ - $1: 40000$ verwendet (1h, RT). Der zweite Antikörper ist Peroxidase-gekoppelt (horse radish peroxidase). Anschliessend erfolgten mindestens 4 Waschschritte von 20 min in 1 x PBS mit 0,05\% Tween 20 (Sigma). 


\subsubsection{Detektion durch Chemilumineszenz}

Zur Detektion der Proteine auf Nitrocellulose-Membranen wurde die Chemilumineszenz-Methode angewendet. Dabei kam der Kit Western Lightning Chemiluminescence der Firma PerkinElmer zum Einsatz. Dieser Kit basiert auf einer verstärkten Version der Chemilumineszenz-Reaktion, in welcher das Enzym horse radish peroxidase die Oxidation von Luminol katalysiert, welches mit einer Lichtemission bei 428 nm einhergeht, die mit einer CCD-Kamera aufgenommen wurde. Dazu wurden die zwei Lösungen (Oxidizing solution und enhanced Luminol) im Verhältnis $1: 1$ gemischt, und der Blot wurde damit mehrfach benetzt. Signale wurden im FujiFilm-LAS 1000 CCD-Reader mit entsprechender ImageReader Software detektiert.

\subsection{Sterilisation von Material und Lösungen}

Hitzebeständige Lösungen, wie 1 x PBS sowie Glas- und Kunststoffmaterial, wurden vor Verwendung durch Autoklavieren $\left(25 \mathrm{~min}, 121^{\circ} \mathrm{C}\right)$ sterilisiert.

Teilweise wurden von den Firmen sterile Einweg-Artikel bezogen.

\subsection{Zellkultur-Techniken}

\subsubsection{Auftauen von gefrorenen Zellen}

Bei $-196^{\circ} \mathrm{C}$ in flüssigem Stickstoff gelagerte Zellen wurden ca. 2 min bei $37^{\circ} \mathrm{C}$ im Wasserbad aufgetaut und in ein bereits mit vorgewärmtem Medium (s. 5.13.2) gefülltes Zentrifugationsröhrchen pipettiert. Das Abzentrifugieren bei $1000 \mathrm{rpm}$ für 2 min diente der Entfernung von DMSO, welches beim Einfrieren zugesetzt wurde. Nach Absaugen des Überstandes wurden die Zellen in frischem Kulturmedium resuspendiert und zum Anwachsen auf $10 \mathrm{~cm}$ Plastikschalen ausgesät.

\subsubsection{Kultur von Säugetier-Zellen}

Zur Kultur von COS 7-Zellen wurde Dulbecco's MEM (Dulbecco's Modified Eagle Medium mit zusäztlich 4,5 g/ L Glucose) verwendet. Zugesetzt wurden $10 \%$ fetales Kälberserum (FKS), 2 mM Glutamin, Penicillin/Streptomycin (Penicillin 100 U/ml; 
Streptomycin $0,1 \mathrm{mg} / \mathrm{ml})$ sowie Natrium-Pyruvat ( $1 \mathrm{mM})$.

Die Inkubation von COS 7-Zellen erfolgte bei $37^{\circ} \mathrm{C}, 10 \% \mathrm{CO}_{2}$-Atmosphäre und $95 \%$ Luftfeuchte. Bei Erreichen einer Konfluenz von ca. 90 \% wurden die Zellen $1: 4$ geteilt. Dazu wurde von der bewachsenen Platte das Medium entfernt und die Zellen mit einem Gemisch aus $0,05 \%(\mathrm{w} / \mathrm{v})$ Trypsin, 0,02\%(w/v) EDTA 5 min bei $37^{\circ} \mathrm{C}$ inkubiert. Nach mehrfachem Auf- und Abpipettieren wurden die Zellen von der Platte und voneinander gelöst und in ein bereits mit Medium gefülltes Röhrchen gegeben. Durch Zugabe des Mediums wurde der tryptische Verdau gestoppt. Nach Abzentrifugieren und Waschen mit 1 x PBS konnten die Zellen entweder für weitere Versuche geerntet oder auf Kulturschalen mit neuem Medium verteilt werden.

\subsubsection{Transfektion von COS 7-Zellen durch Elektroporation}

COS 7-Zellen wuchsen bis $90 \%$ Konfluenz auf den Kulturschalen. Für Interaktionsstudien wie cross-linking-Versuche wurden je drei $15 \mathrm{~cm}$ Platten trypsinisiert, in $1 \mathrm{x}$ PBS gewaschen und in $350 \mu$ l Cytomix resuspendiert. Die Transfektion dieser Zellen geschah mit $20 \mu \mathrm{g}$ DNA durch Elektroporation in BioRad-Küvetten (2mm) im GenePulser Elektroporator (BioRad) bei $50 \mu \mathrm{F}, 200 \Omega$ und $0,7 \mathrm{kV}$ bei einer Zeitkonstante von 1,41,8 ms. Die Zellen wurden anschliessend auf eine $15 \mathrm{~cm}$ Platte pipettiert und $17 \mathrm{~h}$ bei $37^{\circ} \mathrm{C}$ und $10 \% \mathrm{CO}_{2}$ wachsen gelassen.

Für Immunfluoreszenz-Versuche wurde eine analoge Transfektion durchgeführt, jedoch mit $5 \mu \mathrm{g}$ DNA in $200 \mu \mathrm{l}$ Cytomix. Nach der Elektroporation mit den gleichen Parametern wurden lediglich $100 \mu 1$ aus der Küvette auf ein Deckgläschen in einer 6-well-Platte mit $2 \mathrm{ml}$ Medium pipettiert. So wurde eine optimale Zelldichte bei Inkubationszeiten für $17 \mathrm{~h}$ gewährleistet.

\subsection{Immunfluoreszenz}

Über Nacht mit Zellen bewachsene Deckgläschen wurden zur Entfernung von Medium in $1 \times$ PBS gewaschen und 15 min in $4 \%$ (w/v) Paraformaldehyd (PFA, Sigma) bei $37{ }^{\circ} \mathrm{C}$ fixiert. Deckgläschen mit Zellen, die Fusionskonstrukte wie Pipe-GFP exprimierten, wurden nach der Fixierung in 1 x PBS gewaschen und mit Fluorescence Mounting Medium (Dako) auf Objektträgern eingebettet.

Für ohne GFP-Anteil exprimierte Proteine erfolgte erst ein Waschschritt in $50 \mathrm{mM}$ Ammoniumchlorid $\left(\mathrm{NH}_{4} \mathrm{Cl}\right)$ und anschliessend eine Inkubation von 10 min bei $37^{\circ} \mathrm{C}$ zum 
Abblocken freier Aldehydgruppen. Nach 2-maligem Waschen in 1 x PBS wurden die Zellmembranen durch $0,1 \%(\mathrm{w} / \mathrm{v})$ Saponin-PBS für $10 \mathrm{~min}$ bei $37^{\circ} \mathrm{C}$ permeabilisiert. Im Anschluss an weitere 10 min Inkubation in $3 \%(\mathrm{w} / \mathrm{v})$ BSA in Saponin-PBS erfolgte die Inkubation mit dem 1. Antikörper (Anti-Wind) in einer Verdünnung von $1: 150$ in BSA/Saponin-PBS für $1 \mathrm{~h}$ bei $37^{\circ} \mathrm{C}$ in einer feuchten Kammer. Der 1. Antikörper wurde duch folgende Waschschritte entfernt: 5 min 1 x PBS, zweimal 5 min Saponin und kurzes Eintauchen in die BSA/Saponin-PBS. Als 2. Antikörper wurde ein Cy3-konjugierter „Ziege anti-Kaninchen“" Antikörper in der Verdünnung 1 : 1000 eingesetzt. Die Inkubation erfolgte analog zur Inkubation mit dem 1. Antikörper. Nach Entfernen des 2. Antikörpers durch zweimaliges Waschen der Deckgläschen in Saponin-PBS sowie mit 1 x PBS konnten sie mit dem Fluoreszenz Mounting Medium (Dako) eingebettet werden. Zur Immobilisierung wurden die Deckgläschen mit Nagellack versiegelt.

Die Auswertung der Immunfluoreszenzfärbung wurde am Zeiss Axiovert 200 Mikroskop mit entsprechenden Filtern durchgeführt. Die Anregungsfilter für Cy3 und GFP waren 565/30 nm bzw. 480/40 nm, die Emissionsfilter 645/75 nm bzw. 527/30 nm.

\subsection{Protein-Protein-Interaktionen}

\section{$\underline{\text { 5.15.1. Oligomerisierungs-Experimente }}$}

\subsubsection{1. cross-linking von Wind-Wt bzw. Wind-Mutanten mit Disuccinimidyl Suberat (DSS)}

Wie in 5.13.3 beschrieben, wurden transfizierte Zellen geerntet. Nach Resuspendieren der Zellen in KHM-base-Puffer erfolgte ein Zentrifugationsschritt (1 min, $13000 \mathrm{rpm}, \mathrm{RT})$. Das Zellpellet wurde danach in $1 \mathrm{ml}$ KHM-Puffer + Proteaseinhibitor (Complete tablet, Roche, 18,5 mg EDTA, hemmt Serin-, Cystein und Metalloproteinasen) gelöst und erneut zentrifugiert. Durch 3-maliges Passsagieren durch Kanülen mit abnehmenden Durchmesser (20 G, 23 G, 27 G) wurde das Zellpellet zerstört und somit ein Zell-Lysat hergestellt.

In Eppendorf-Gefässe wurden für jede Probe $250 \mu 1$ dieses Zell-Lysats pipettiert.

DMSO wurde in den Deckel pipettiert zu je $40 \mu 1,37,5 \mu 1,35 \mu 1$ und $20 \mu 1$. Dann wurde der cross-linker Disuccinimidyl Suberat (DSS, $100 \mathrm{mM}$ in DMSO) zu einer Endkonzentration von $0 ; 0,25 ; 0,5$ und $2 \mathrm{mM}$ in den Deckel hinzupipettiert. Nach Deckelschliessung wurde sofort gemischt. Das cross-linking wurde für $30 \mathrm{~min}$ bei RT durchgeführt und durch Zugabe von 20mM Stop-Mix (Glycin) und Inkubation für $15 \mathrm{~min}$ auf Eis beendet. Anschliessend 
wurden die Proben abzentrifugiert (13000 rpm). Das erhaltene Pellet wurde in ca. $40 \mu 11 \mathrm{x}$ PBS resuspendiert, mit $100 \mu \mathrm{l}$ Laemmli-Puffer $+20 \mu \mathrm{l}$ DTT versetzt und bei $95{ }^{\circ} \mathrm{C} 5 \mathrm{~min}$ denaturiert.

Der Überstand wurde anschliessend einer TCA-Fällung (Endkonzentration $8 \%$ TCA) unterzogen, zentrifugiert und das Sediment einmalig mit Aceton gewaschen. Das nun erhaltenen Pellet wurde ebenso in PBS gelöst und mit Laemmli-Puffer und DTT versetzt wie oben beschrieben.

Alle Proben wurden je nach Grösse der Proteine auf 12,5-, 10- oder 7,5- \%igen Gelen aufgetrennt.

Ebenso wurden Cross-linking Versuche mit Pipe-GFP durchgeführt.

Verwendete Puffer beim cross-linking:

\begin{tabular}{|l|l|}
\hline $200 \mathrm{mM}$ Magnesium-Acetat, $50 \mathrm{ml}$ & \\
\hline KHM-base, $400 \mathrm{ml}$ & $20 \mathrm{mM}$ Hepes, $110 \mathrm{mM}$ Kalium-Acetat, $\mathrm{pH} 7,2$ \\
\hline KHM, $100 \mathrm{ml}$ & KHM-base + 2mM Magnesium-Acetat, $\mathrm{pH} 7,2$ \\
\hline $100 \mathrm{mM}$ DSS, $200 \mu \mathrm{l}$ & in DMSO \\
\hline Stop-Mix, $5 \mathrm{ml}$ & $200 \mathrm{mM}$ Glycin \\
\hline $1 \mathrm{M}$ Glycin, $20 \mathrm{ml}$ & In KHM-base, $\mathrm{pH} 7,2$ \\
\hline DMSO & Raumtemperatur \\
\hline $30 \%(w / v)$ TCA & eiskalt \\
\hline Aceton & eiskalt \\
\hline
\end{tabular}




\section{Ergebnisse}

Wind ist ein wichtiger Faktor in der Dorso-Ventral-Entwicklung in D. melanogaster, der für die Golgi-Lokalisation von Pipe, einer mutmasslichen 2-O-Sulfotransferase notwendig ist.

Im Rahmen dieser Arbeit werde ich zeigen, dass Wind direkt mit Pipe interagiert. Durch Expression verschiedener Mutanten von Wind im Translokationsassay mit Pipe wurde eine Peptid-Bindestelle identifiziert: sie liegt in der Thioredoxin-Domäne von Wind. Mutationen in der D-Domäne zeigen soweit keinen Hinweis auf eine weitere Bindestelle. Beide Domänen (Thioredoxin- und D-Domäne) sind aber für den Transport von Pipe in den Golgi erforderlich. Beide Domänen sind jedoch nicht in der Lage, Pipe zu prozessieren, wenn sie separat in COS7-Zellen exprimiert werden. Eine Pipe-Prozessierung in den Golgi findet erst statt, wenn die D-Domäne kovalent an die Thioredoxin-Domäne über einen Linker gebunden ist.

Weiterhin werde ich zeigen, dass Wind nur als Dimer Pipe prozessieren kann. Dieses könnte bedeuten, dass der Transport von Pipe in den Golgi von der Anwesenheit beider ThioredoxinDomänen abhängig ist, unter Beteiligung von einer oder beiden D-Domänen.

\subsection{Direkte Interaktion von Wind mit Pipe}

\subsubsection{Deletions-Mutagenese von Wind}

Von Wind wurden folgende Deletionskonstrukte amplifiziert und im Pipe-Translokationsassay im Vergleich zu full-length Wind (Wind-WT) untersucht (Abb.15, 1a-c): WindABCD $\triangle \mathrm{KEEL}^{*}$ (Abb.15, 2a-c), Wind mit verkürzter D-Domäne ABCint.KEEL* (Abb.15, 3a-c), WindABC-KEEL* (Abb.15, 4a-c), WindABC* (Abb.15, 5a-c). Desweiteren wurde ein Fusionskonstrukt bestehend aus der Thioredoxin-Domäne von Wind und der DDomäne von ERp28 WindABC-ERp28D (Abb.15, 6a-c) generiert. Darüberhinaus wurde untersucht, ob die D-Domäne ( $\mathrm{ssD}^{*}$ ) von Wind allein in der Lage ist, Pipe zu translozieren (Abb.15, 7a-c). Die Fluoreszenz der transfizierten Zellen aller Versuche wurde mit den gleichen Messparametern (Belichtungsdauer, Objektiv) bestimmt. Wenn nicht anders geschildert, wurden Translokationsversuche von Pipe mit Wind Deletions- oder Punktmutanten dreimalig durchgeführt. 
In allen durchgeführten Immunfluoreszenzversuchen ist zu erkennen, dass sowohl Wind-WT als auch die untersuchten Wind-Mutanten mit Wind-spezifischen Antikörpern nachgewiesen werden können und immer im ER lokalisiert sind. Pipe ist direkt im GFP-Kanal zu sehen, da hier stets ein Pipe-GFP-Fusionskonstrukt im Translokationsassay zur Anwendung kommt. Aus den Ergebnissen der Deletionsversuche von Wind kann man erkennen, dass das KEELSignal am C-Terminus von Wind für die Retention des Proteins im ER nicht erforderlich ist. Dieses lässt sich daraus schliessen, dass im Konstrukt WindABCD $\triangle K_{E E L *}^{*}$ eine vergleichbare Verteilung im ER zum Wind Wildtyp vorherrscht (Abb.15, 2a und b). Ebenso hat die Deletion der KEEL-Sequenz keinen Effekt auf die Pipe-Translokation. Pipe wird bei Co-Transfektion mit WindABCD $\triangle$ KEEL ebenso in den Golgi transportiert (Abb.15, 2c).

Erst bei der teilweisen Deletion der D-Domäne von Wind im Konstrukt WindABCint.KEEL* wird die Translokation von Pipe verhindert (Abb.15, 3c). Dieses bedeutet, dass die D-Domäne für den Transport von Pipe erforderlich ist.

Dieses wird auch bei der Co-Expression von sowohl WindABC-KEEL* als auch WindABC* mit Pipe deutlich. Durch das Fehlen der D-Domäne in diesen Konstrukten sind die Proteine nicht mehr in der Lage, Pipe in den Golgi zu translozieren (Abb.15, 4c und 5c).

Gleichzeitig kann festgestellt werden, dass auch das Fehlen der KEEL-Sequenz scheinbar keine andere Wind-Verteilung im ER bewirkt (Abb.15, 4a,b, 5a, b).

Aufgrund dieser Ergebnisse sollte ebenso untersucht werden, ob die D-Domäne von Wind durch die seines Säuger-Homologs ERp28 ersetzbar ist.

Die Transfektion mit dem zu diesem Zweck amplifizierten Fusionskonstrukt WindABCERp28D* zeigt, dass die D-Domäne von ERp28 durchaus die Funktion der D-Domäne von Wind erfüllen kann. Bei Co-Transfektion dieses Fusionskonstrukts mit Pipe zeigt sich eine Golgi-Verteilung vergleichbar zu Transfektionsexperimenten mit Wind-Wildtyp (Abb.15, 6c). Die D-Domäne von Wind allein ist jedoch nicht in der Lage, Pipe in den Golgi zu translozieren (Abb.15, 7c).

Zusammenfassend lässt sich sagen, dass eine Prozessierung von Pipe nur stattfinden kann, wenn das Wind-Protein über seine eigene komplette D-Domäne oder die des SäugerHomologs ERp28 verfügt. 


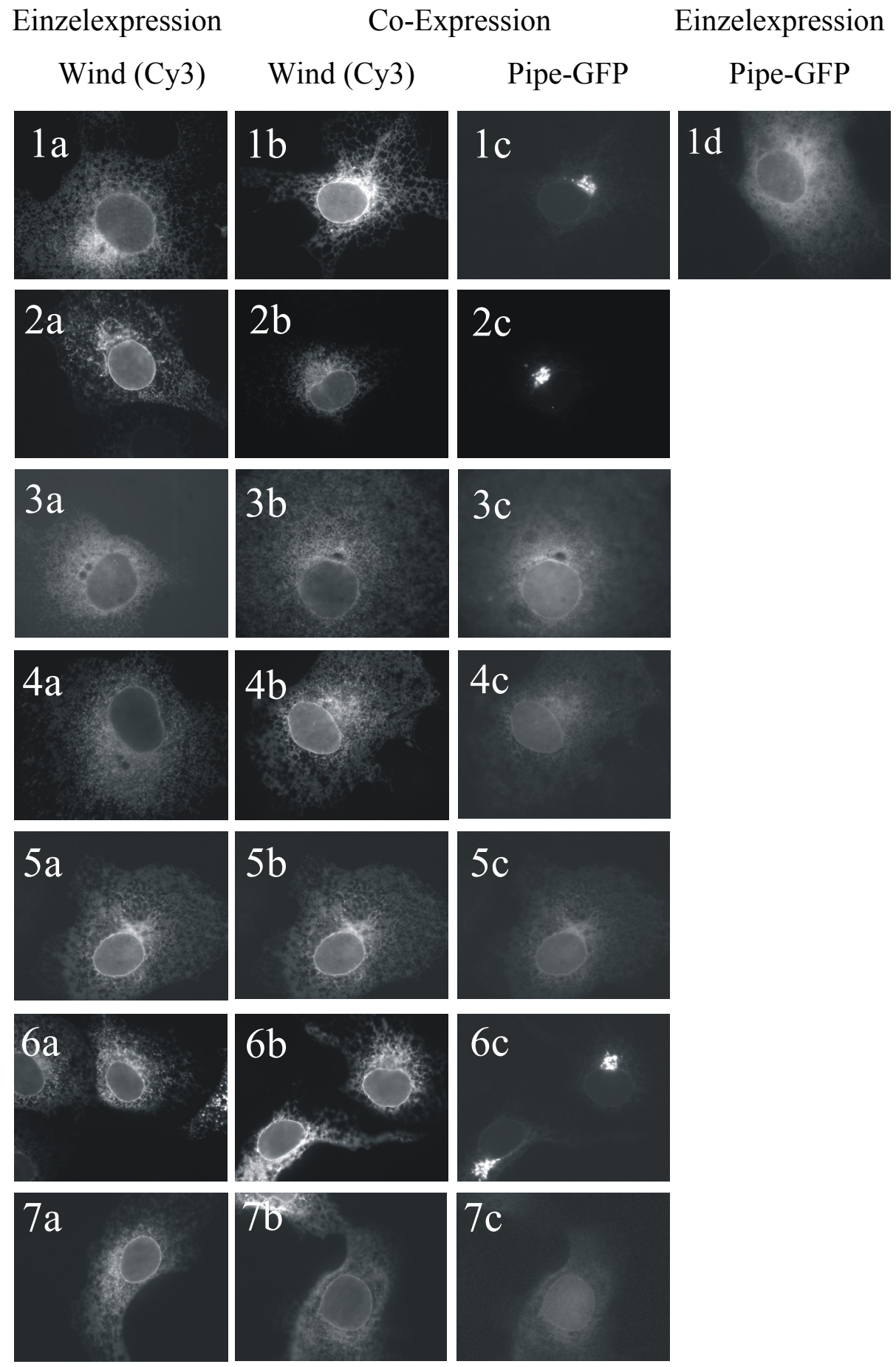

Abb. 15: Effekte verschiedener Wind-Mutationen auf die Prozessierung von Pipe in COS7-Zellen.

In der ersten Spalte (Abb.15, 1a-c) ist die Transfektion von Wind-WT dargestellt: 1a zeigt die Einzelexpression von Wind, nachgewiesen mit Wind-spezifischen Antikörpern, $1 \mathrm{~b}$ und 1c zeigen die Co-Transfektion von Wind und Pipe. Wind ist jeweils im ER lokalisiert (Abb.15, 1a, 1b). 1c zeigt die typische Golgi-Verteilung von PipeGFP bei Co-Expression mit Wind-WT, im Vergleich zur Einzelexpression von Pipe-GFP (1d). In (2) ist die Transfektion der Mutante WindABCD $\triangle K_{E E L *}^{*}$ dargestellt: 2a zeigt die separate Expression von Wind ABCD $\triangle$ KEEL*. Die Bilder 2b und 2c zeigen die Co-Transfektion dieser Mutante mit Pipe im Cy3- bzw. im GFP-Kanal. Pipe wird trotz Fehlen des KEEL-Signals in den Golgi transloziert (Abb.15, 2c), wobei Wind im ER lokalisiert bleibt (Abb.15, 2a, 2b).

Unter 3 ist die Transfektion von WindABCint.KEEL* dargestellt. In 3a ist die Einzelexpression dieser Mutante mit der ER-Verteilung zu sehen. In $3 b$ und $3 c$ ist die Co-Transfektion dieser Mutante mit Pipe gezeigt. Im Unterschied zum Wind-WT wird mit der Mutante WindABCint.KEEL* Pipe nicht mehr in den Golgi transloziert (3c).

In den Abbildungsreihen 4a-c und 5a-c sind die Ergebnisse der Einzel- bzw. Co-Expression von WindABCKEEL* und WindABC* mit Pipe dargestellt. 4a und 5a zeigen wiederum die Einzelexpression dieser Mutanten 
mit der ER-Lokalisation. 4b und 5b zeigen die Wind-Expression im ER. In beiden Mutanten erfolgt bei CoTransfektion mit Pipe keine Golgi-Translokation. Pipe bleibt im ER lokalisiert (4c, 5c).

In 6a-c sind Experimente mit dem Fusionskonstrukt bestehend aus WindABC und der D-Domäne von ERp28 dargestellt. Es verhält sich wie Wind-WT (6a und b) und ist im ER lokalisiert. Trotz des Austausches der DDomäne von Wind gegen die des ERp28 wird von Pipe in den Golgi transloziert (6c).

In $7 \mathrm{a}-\mathrm{c}$ ist die Expression der D-Domäne ( $\mathrm{ss}^{*}$ ) von Wind dargestellt. Die D-Domäne von Wind allein ist nicht in der Lage, die Pipe-Translokation in den Golgi zu katalysieren (7c).

\subsubsection{Identifizierung einer Substrat-Bindestelle in der Thioredoxin-Domäne von Wind}

Ausgehend von der Kristallstruktur von Wind wurden oberflächlich gelegene Aminosäuren ausgewählt, mutiert und die Fähigkeit der resultierenden Mutanten untersucht, Pipe zu prozessieren. Dabei wurden die Mutationen so gewählt, dass sie die Dimerisierung nicht messbar beeinflussten (s. 6.2 Oligomerisierungsexperimente). In der ThioredoxinDomäne wurden 10 solcher Mutationen gefunden, die den Transport von Pipe zum Golgi verhindern. Dazu gehören Wind V28D, V28Y, D50N, D50A, Y53S, Y55K, E60Q, K84D, Y86Q und P106D (s. Abb.16). Bis auf Wind K84D sind alle Aminosäuren in Windhomologen Proteinen (ERp28, ERp29) konserviert. 


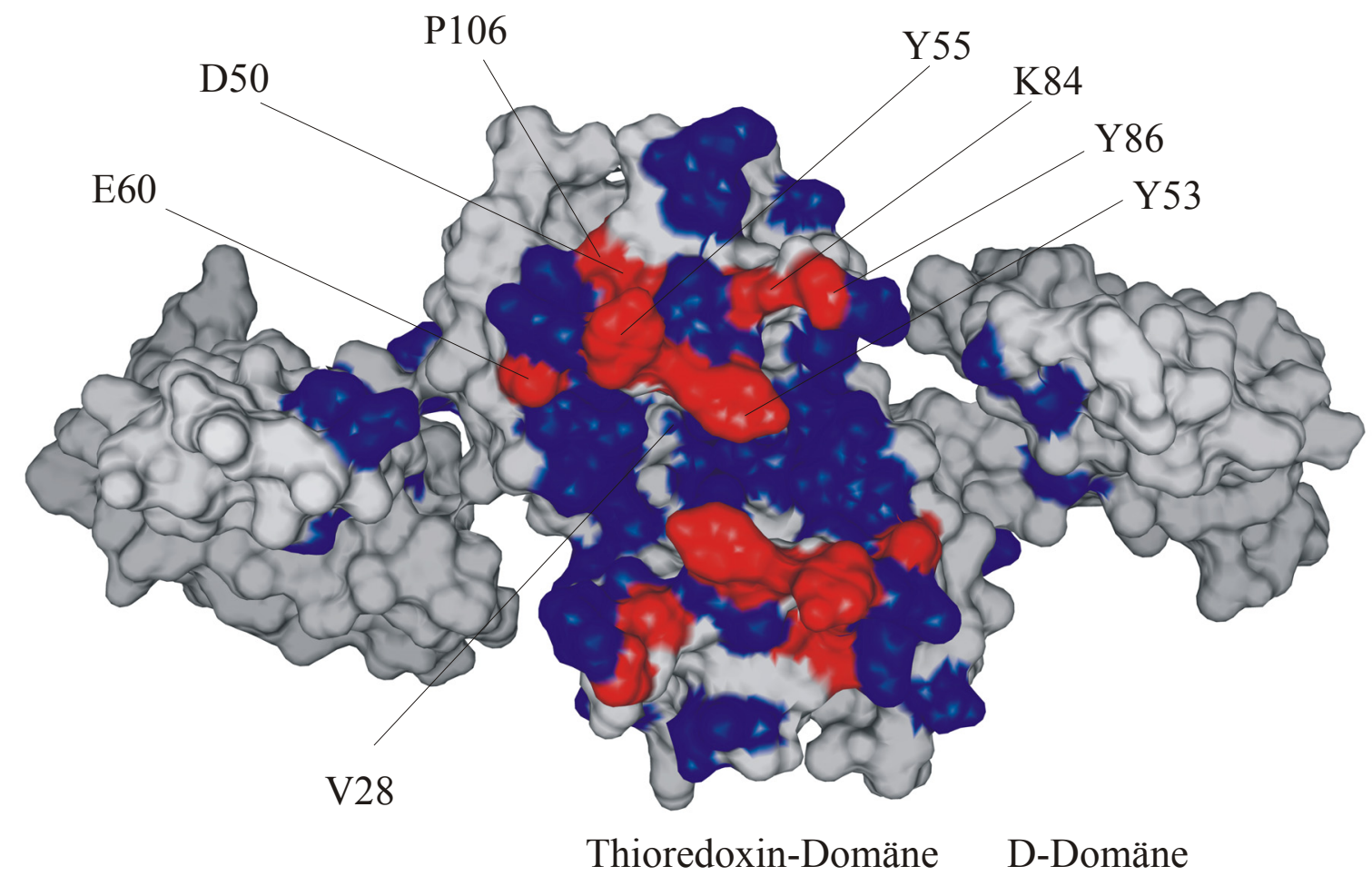

Abb. 16: Struktur des Wind-Dimers.

Dargestellt sind in rot solche Punktmutationen in Wind, die die Pipe-Prozessierung verhindern. In blau sind Wind-Mutanten dargestellt, die keinen Effekt auf den Pipe-Transport haben. V28 ist in dieser Abbildung hinter Y53 verborgen und somit nicht rot dargestellt.

In Transfektions-Versuchen mit anschliessender Immunfluoreszenzmikroskopie zeigt sich folgende Lokalisation der Proteine Wind und Pipe (Abb. 17): die Wind-Mutanten Y55K, Y86Q und P106D aber nicht E60Q zeigen in der separaten Transfektion eine dem Wind-WT vergleichbare Expression und Lokalisation (1a, 3a, 4a). Alle verhindern die Translokation von Pipe in den Golgi bei Co-Expression dieser Wind-Mutanten mit Pipe (Abb.17, 1c-4c). Bei der Wind-Mutante Y55K zeichnet sich eine Verringerung der Proteinmenge sowohl von Wind Y55K als auch von Pipe bei Co-Transfektion ab (1b, 1c). Daraus kann man schliessen, dass Wind Y55K eine sehr stabile Bindung mit Pipe eingeht. Diese Bindung ist so stabil, dass die Proteine nach ihrer Interaktion nicht getrennt, sondern gemeinsam abgebaut werden. Etwas anders verhält es sich bei der Co-Transfektion von Wind Y86Q mit Pipe: hier ergibt sich keine Verringerung der Proteinmenge von Wind Y86Q (3b), jedoch nimmt die PipeExpression ab (3c). Auch hier kommt es zu einer starken Bindung von Wind Y86Q an Pipe.

Die Mutante Wind E60Q wird insgesamt schwächer exprimiert, unabhängig davon, ob eine Einzel- oder Co-Transfektion vorliegt $(2 \mathrm{a}, 2 \mathrm{~b})$. Dieses wurde in allen drei durchgeführten Experimenten beobachtet. Bezüglich der Pipe-Expression in der Co-Transfektion ist im Vergleich zu Pipe-WT keine Änderung zu beobachten (2c). 
Die Mutante Wind P106D verhält sich in Einzel- wie auch Co-Expression wie Wind-WT. Es kommt zu keiner Änderung im Expressionsniveau (4a-c).
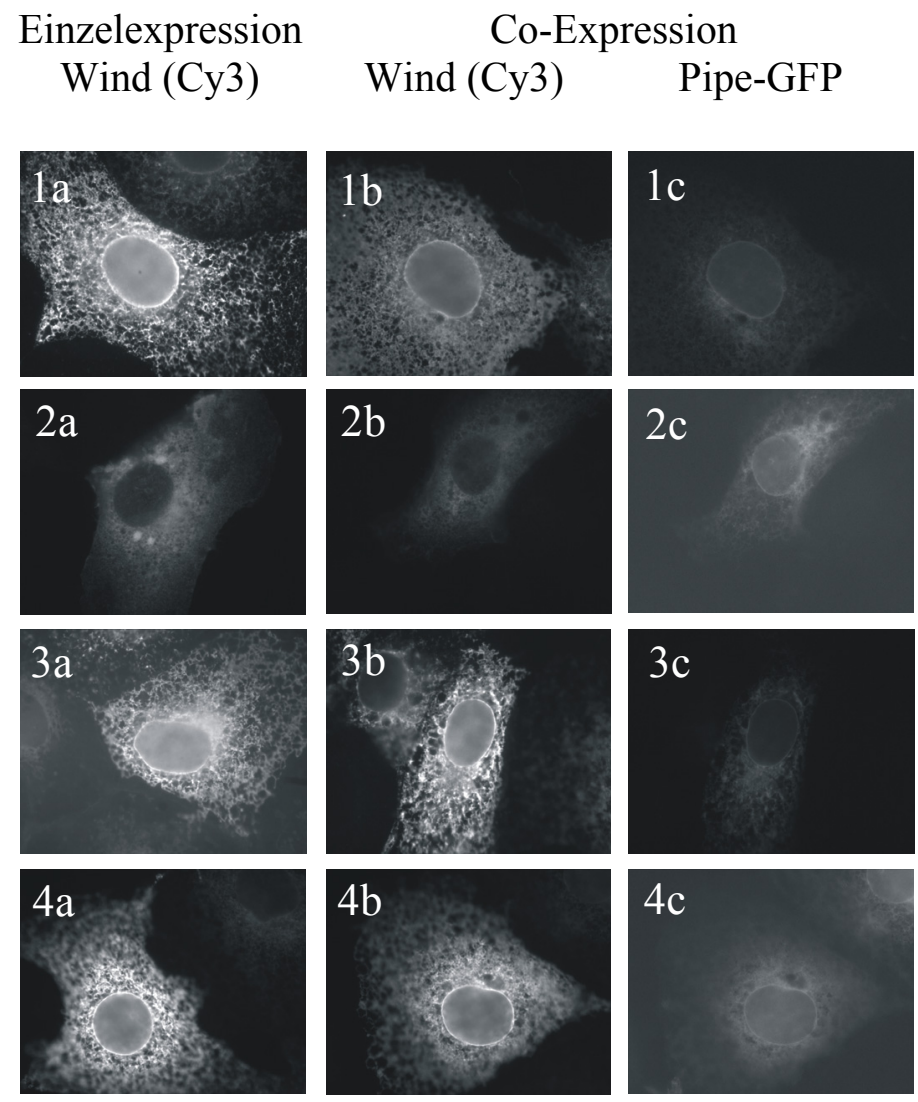

Abb. 17: Effekte von Wind Punktmutationen auf den Transport von Pipe zum Golgi in COS7-Zellen. Dargestellt sind die Wind Mutanten Y55K (1a-c), E60Q (2a-c), Y86Q (3a-c) und P106D (4a-c). In allen CoTransfektionen dieser Mutanten mit Pipe bleibt die Translokation von Pipe in den Golgi aus (1c-4c). Bei der Mutante Wind Y55K fällt auf, dass die detektierbare Menge an Wind und Pipe bei der Co-Transfektion beider Proteine abnimmt (1b, 1c).

Die Wind Mutante E60Q zeigt in Einzel- wie auch Co-Transfektion eine insgesamt schwächere Expression (2a, 2b) und keine typische ER-Verteilung (2c). So ist z.B. die Kernmembran im Vergleich zu anderen WindMutanten nicht so deutlich zu erkennen. Auch bei der Co-Transfektion von Y86Q mit Pipe ist zu erkennen, dass die nachweisbare Pipemenge abnimmt (3c).

4a-c zeigen die Expression von Wind P106 ähnlich zu Wind-WT.

Bei einigen Wind-Mutationen (D50N, Y53S und K84D) wurde sogar festgestellt, dass nicht nur der Pipe-Transport verhindert wurde, sondern dass in co-transfizierten Zellen die nachweisbaren Mengen sowohl von Wind als auch von Pipe im Vergleich zum Wind-WT abnehmen (s. Abb.18a). Bei im ER retinierten Proteinen, die nicht weiter transportiert und als falsch gefaltet erkannt werden, kommt es zu ER-assoziierter Degradation (ERAD) dieser Proteine (s. Einleitung). Dieser Prozess ist Proteasom-abhängig. Die Beteiligung von ERAD an den beobachteten Effekten der Mutanten D50N, Y53S und K84D konnte durch Einsatz des Proteasom-Inhibitors MG 132 bestätigt werden. 
$\mathrm{Zu}$ diesem Zweck wurden transfizierte Zellen $13 \mathrm{~h}$ inkubiert, anschliessend mit dem Proteasom-Inhibitor MG132 $(10 \mu \mathrm{M})$ für $4 \mathrm{~h}$ behandelt und im Fluoreszenzmikroskop auf ihre Expression überprüft (s. Abb. 18a). Als Kontrollen dienten transfizierte Zellen, die nicht mit dem Inhibitor behandelt wurden.

Es ist kein Unterschied in der nachweisbaren Proteinmenge $\mathrm{zu}$ sehen, wenn die WindMutanten in der Einzelexpression mit oder ohne Proteasominhibitor MG 132 für $4 \mathrm{~h}$ inkubiert wurden. Dies deutet darauf hin, dass die Protein-Expression und die Stabilität dieser Punktmutanten im ER ähnlich sind. So ist die nachweisbare Menge der Mutante Wind D50N ohne Proteasominhibitor-Behandlung (Abb. 18a,1a) vergleichbar mit der bei der Inkubation mit MG 132 gefundenen Proteinmenge (Abb. 18a, 1b). Bei Co-Expression von Wind D50N mit Pipe ist eine Abnahme von D50N im Cy3-Kanal zu erkennen (1c), welche durch Inkubation mit MG 132 verhindert wird (1d). In der Abbildung 18, 2a-d ist als Vergleich dazu die Pipe-Expression dargestellt, 2a zeigt Pipe ohne Inhibitor-Behandlung. Bei Einzelexpression von Pipe führt MG $132 \mathrm{zu}$ einem reduzierten Abbau (2b). Bei Co-Transfektion von Wind D50N mit Pipe zeigt sich ohne MG 132-Inkubation eine Abnahme der WindMutante (2c) verglichen mit der Einzelexpression ohne Inhibitor (2a). Die Hemmung des Wind D50N-Abbaus wird im Falle der Co-Expression durch MG 132 besonders deutlich (2d). Diese Ergebnisse zeigen, dass unter diesen Bedingungen Wind D50N zusammen mit Pipe degradiert wird.

In der Abbildung 18a, 3a-d ist die Mutante Wind Y53S dargestellt. Bei Einzelexpression von Wind Y53S mit oder ohne MG 132-Behandlung ist kein Unterschied zu erkennen (3a u. 3b). Bei Co-Transfektion mit Pipe ist aber eine deutliche Abnahme von Y53S im Cy3-Kanal zu beobachten (3c), die unter MG 132-Behandlung ausbleibt (3d). Auch in diesem Versuch kommt es zu einem reduzierten Abbau von Pipe bei MG 132-Behandlung (4b) im Vergleich zu mit Pipe transfizierten Zellen ohne MG 132-Inkubation (4a). Bei Co-Expression mit Wind Y53S wird ebenso eine verstärkte Abnahme von Pipe (ohne MG 132) im GFP-Kanal beobachtet (4c), welches durch MG 132 deutlich gehemmt wird. Auch in diesem Versuch ist eine Co-Degradation von Wind und Pipe zu beobachten. 
Die gleichen beschriebenen Effekte treffen auch für die Mutante Wind K84D zu (Abb. 18a, 5a-d und 6a-d). Bei Einzelexpression hat MG 132 keinen Einfluss auf die nachweisbare Proteinmenge an Wind K84D (Abb. 18a, 5a-b). Bei Co-Transfektion von Wind K84D mit Pipe kommt es zu einer starken Abnahme von Wind K84D (5c), die unter MG 132 verhindert wird (5d). Auch bei der Mutante Wind K84D ist eine Co-Degradation von Wind mit Pipe zu erkennen (Abb. 18a, 6a-d).

Die Ergebnisse dieser Versuche lassen darauf schliessen, dass die Wind-Mutanten D50N, Y53S und K84D aufgrund der Degradation bei Co-Expression dieser Mutanten mit Pipe eine starke Interaktion mit Pipe zeigen. Im Vergleich dazu ist bei Wind-WT kein Unterschied in der Proteinmenge zu sehen, wenn Zellen in Einzel- bzw. Co-Expression mit und ohne Inhibitor inkubiert werden (Abb. 18b, 1a-d). Bei der Co-Transfektion von Wind-WT mit Pipe ist bei behandelten Zellen eine geringere Verteilung von Pipe im Golgi zu sehen (Abb. 18b, 1f).

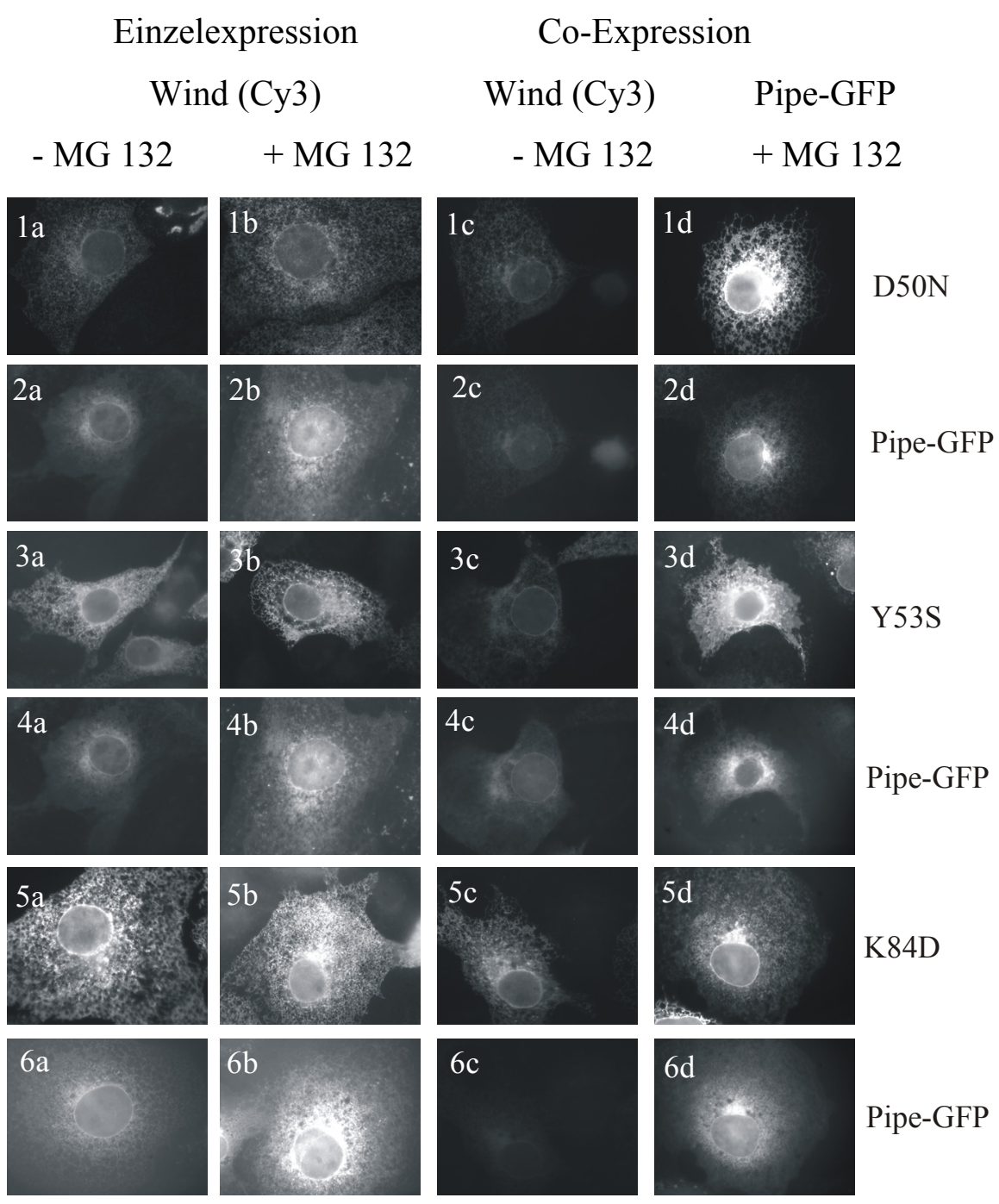

Abb. 18a: Spezifische Punktmutationen in Wind hemmen nicht nur die Translokation von Pipe, sondern beeinflussen auch den Abbau von Wind-Mutanten und Pipe. 


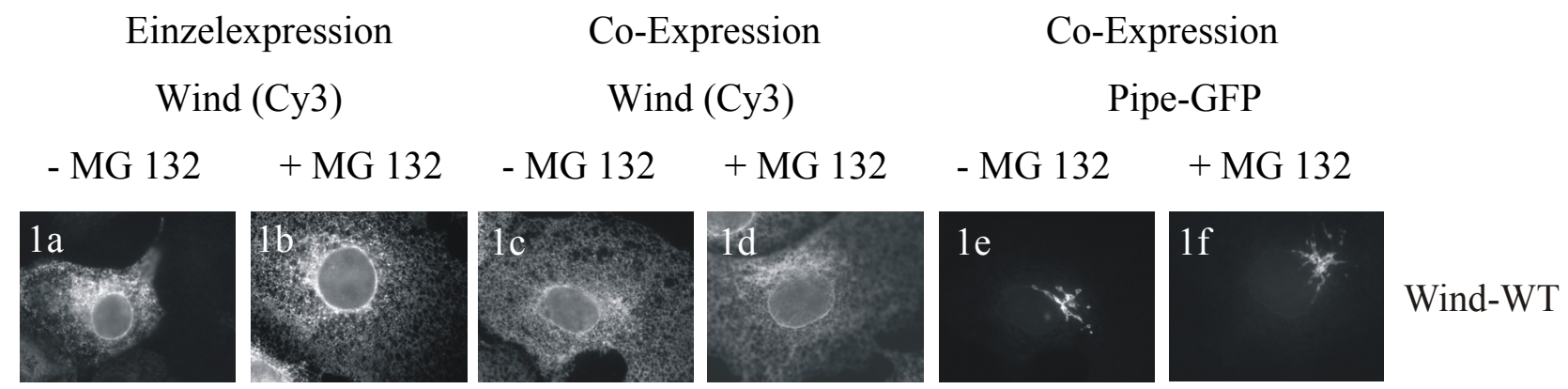

Abb. 18b: Einfluss von MG 132 auf die Expression von Wind-WT.

Abb. 18a, 1a und 1b zeigen die Mutante Wind D50N in der Einzelexpression mit und ohne MG 132.

Pipe im ER. In $1 \mathrm{c}$ ist die Co-Transfektion mit Pipe ohne MG $132 \mathrm{zu}$ sehen, in 1d die Co-Transfektion nach 4h MG 132-Inkubation $(10 \mu \mathrm{M})$ der Zellen. Die Menge an Wind D50N nimmt bei Co-Transfektion mit Pipe ab (1c). In co-transfizierten Zellen ist unter MG 132 ein Anstieg von Wind D50N zu beobachten (1d). In 2a und 2b ist die alleinige Expression von Pipe ohne und mit MG 132 dargestellt. Abb. 18a, 2b zeigt bei Pipe mit MG 132Inkubation einen reduzierten Abbau im Vergleich zu unbehandelten Zellen (2a). Bei Co-Transfektion mit Wind D50N nimmt die Menge an Pipe ohne Inhibitor weniger stark ab als bei alleiniger Expression ohne MG 132 (2c). Unter MG 132-Einfluss ist der Abbau von Pipe bei Co-Transfektion mit Wind D50N deutlich vermindert (2d).

In 3a-d ist die Mutante Wind Y53S dargestellt. Einzeln exprimiert zeigt sich bei dieser Mutante eine vergleichbare ER-Expression in Anwesenheit (3b) oder Abwesenheit (3a) von MG 132. Nach der CoTransfektion mit Pipe zeigt sich ohne Inhibitor-Behandlung eine Abnahme der Wind Y53S-Expression (3c). Bei Inkubation mit MG 132 zeigt sich eine vermehrte Expression von Wind Y53S in co-transfizierten Zellen (3d).

In 4a-d sind analog zu 2a-d die mit Pipe-GFP separat und co-transfizierten Zellen im GFP-Kanal zu sehen. Es zeigt sich eine erhöhte Menge an Pipe bei Inhibitor-behandelten Zellen in der Einzeltransfektion (4b) im Vergleich zu unbehandelten, mit Pipe transfizierten Zellen (4a). Nach MG 132-Behandlung ist der Abbau von Pipe in co-transfizierten Zellen deutlich gehemmt (4d). Dabei kommt es wiederum zu einer starken Abnahme der Pipe-Menge nach der Co-Transfektion mit Wind Y53S (4c).

Wind K84D wird bei alleiniger Expression mit oder ohne Inhibitor vergleichbar im ER exprimiert (5a, 5b). In co-transfizierten COS7-Zellen zeigt sich eine Abnahme von Wind K84D (5c) ohne MG 132. Bei Inkubation mit Inhibitor kommt es in co-transfizierten Zellen zu einem starken Anstieg von Wind K84D (5d).

In $6 \mathrm{c}$ und $6 \mathrm{~d}$ sind analog zu $2 \mathrm{c}$ und $2 \mathrm{~d}$ die co-transfizierten Zellen im GFP-Kanal zu sehen (Pipe-GFP). Es zeigt sich unter MG 132 ein reduzierter Abbau in der Einzeltransfektion (6b) im Vergleich zu unbehandelten, allein transfizierten Pipe-Zellen (6a). In co-transfizierten nicht behandelten Zellen nimmt die Pipe-Menge verglichen mit nicht behandelten Zellen bei Einzeltransfektion deutlich ab (6c)

Nach MG 132-Behandlung zeigt sich ein reduzierter Abbau von Pipe in co-transfizierten Zellen (6d).

In Abb. 18b, 1a-f ist als Vergleich Wind-WT mit und ohne Behandlung von MG 132 gezeigt. Bei Einzel- und auch Co-Expression mit Pipe ist die Menge an detektierbaren Wind-Proteins gleich (7a-d). Bei Co-Expression mit Pipe zeigt sich bei MG 132-Behandlung eine geringere Golgi-Verteilung von Pipe (7f) als in unbehandelten Zellen (7e).

Die Co-Degradation von Wind in diesen Mutanten zusammen mit Pipe sollte auch biochemisch nachgewiesen werden. Dazu wurden COS7-Zellen wie beschrieben mit den Wind-Mutanten D50N, Y53S und K84D und mit Pipe co-transfiziert. Bei der Hälfte der CoTransfektionen wurden nach $13 \mathrm{~h}$ Inkubation $10 \mu \mathrm{M}$ Proteasom-Inhibitor MG 132 zugesetzt und 4 weitere Stunden inkubiert. Die andere Hälfte wurde nicht mit MG 132 behandelt und $17 \mathrm{~h}$ inkubiert. Nach der Inkubation wurden die Zellen durch Trypsinisierung geerntet, in $180 \mu \mathrm{l}$ PBS suspendiert, mit 2-fach Probenpuffer und DTT versetzt und ihre Proteinmenge mit GFP-Antikörpern in Western Blots nachgewiesen. Es zeigt sich eine fast doppelt so grosse Menge an Pipe-Protein in den durchgeführten Transfektionsversuchen nach Behandlung mit MG 132 im Vergleich zu nicht behandelten Zellen (s. Abb. 18c). Bei Wind 
kam es nur zu einem sehr geringen Anstieg der Proteinmenge nach MG 132-Behandlung (Daten nicht gezeigt).

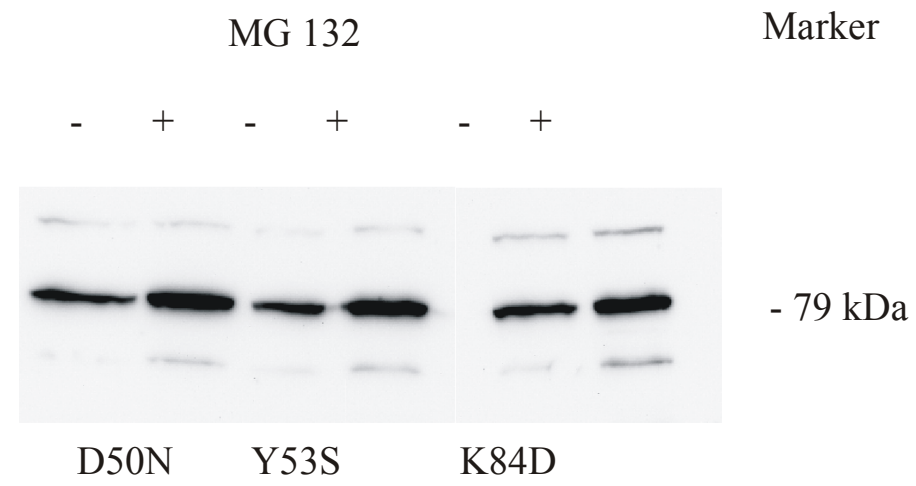

Abb. 18c: Einfluss von MG 132 auf die Proteinmenge von D50N, Y53S und K84D.

In allen Mutanten, bei denen in der Immunfluoreszenz eine Co-Degradation von Wind mit Pipe beobachtet wurde, ist bei Behandlung mit MG 132 auch ein Anstieg der Menge nachweisbaren Proteins auf dem Western Blot zu verzeichnen. Der hier gezeigte Blot stellt den Nachweis von Pipe mit GFP-Antikörpern auf einem 7 \%igen SDS-Gel dar. Als Proteinmarker dient Rinderalbumin (79 kDa).

Weitere Mutationen von D50 im Wind-Protein zu Alanin und Serin (D50A, D50S) wurden durchgeführt. Bei Einzel- wie auch bei Co-Transfektion von Wind D50A oder D50S mit PipeGFP ist eine zum Wildtyp vergleichbare Menge der Mutanten sichtbar (s.. Abb. 19, 1a-b, 2a2b). Die Mutante Wind D50S ist in der Lage eine teilweise Translokation von Pipe in den Golgi zu katalysieren (2c), während Wind D50A keine messbare Aktivität zeigt (1c).

Einzelexpression

$$
\text { Wind (Cy3) }
$$
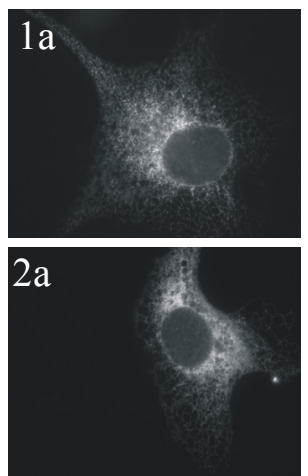

\section{Co-Expression}

Wind (Cy3)

Pipe-GFP
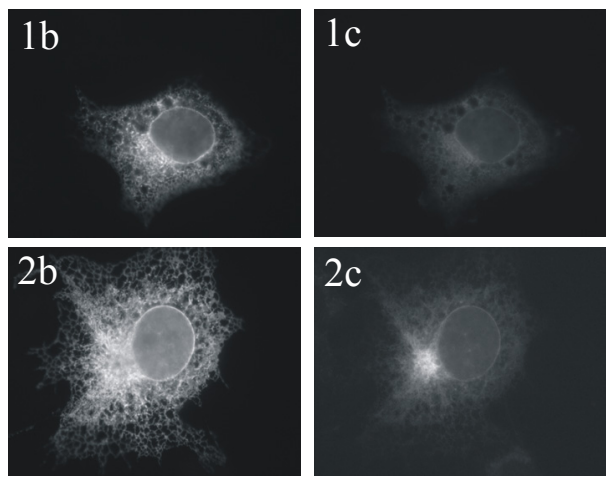

Abb. 19: Weitere Mutationen von D50 haben teilweise Einfluss auf die Translokation von Pipe.

In 1a-c ist die Expression von Wind D50A, in 2a-c die Expression von Wind D50S dargestellt. Während Wind D50S die Translokation von Pipe teilweise katalysiert (2c), ist Wind D50A nicht in der Lage, Pipe zu prozessieren. Pipe bleibt ausschliesslich im ER lokalisiert (1c). Die hier gezeigten Experimente wurde nur einmal durchgeführt. 
Bei näherer Betrachtung der bereits dargestellten Punktmutationen in Wind (D50N, D50A, Y53S, Y55K, E60Q, K84D, Y86Q und P106D) fällt auf, dass von acht durchgeführten Mutationen, die einen Effekt auf die Pipe-Prozessierung zeigen, drei Tyrosine (Y53S, Y55K und Y86Q) beteiligt sind. Diese drei Tyrosine bilden ein Cluster auf der Oberfläche des Wind-Proteins. Um herauszufinden, ob die fehlende Aktivität dieser Mutanten auf den hydrophoben oder polaren Charakter der Tyrosine zurückzuführen ist, wurden diese drei Tyrosine zu Phenylalanin mutiert. Die Mutanten von Wind Y53F, Y55F und Y86F haben jedoch keinen negativen Effekt hinsichtlich der Translokation von Pipe in den Golgi (s. Abb. 20).

Einzelexpression Co-Expression

Wind (Cy3) Wind (Cy3)

Pipe-GFP
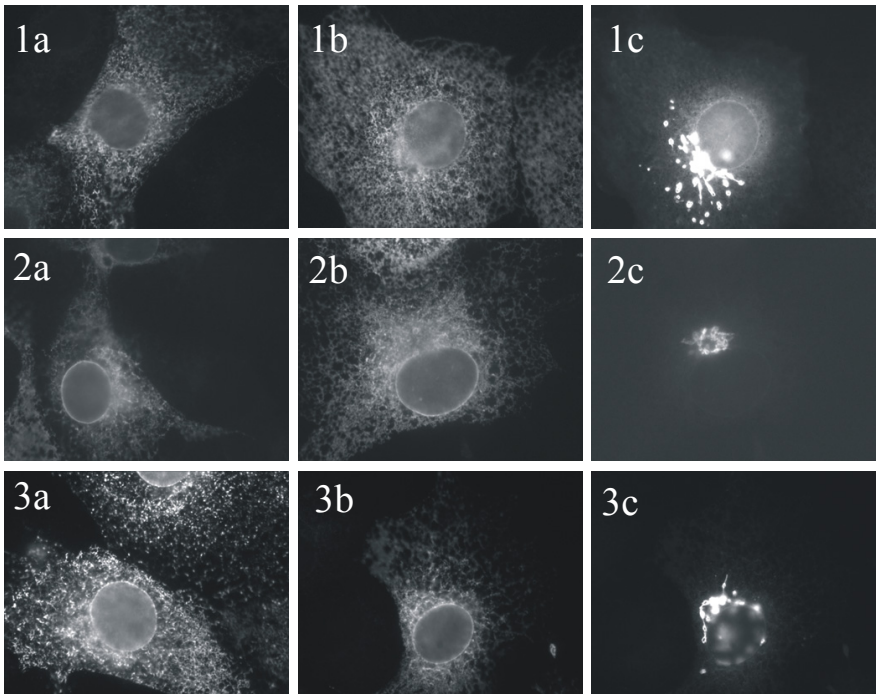

Abb. 20: Der Austausch von Tyrosin gegen Phenylalanin in den Positionen 53, 55 und 86 des WindProteins hat keinen negativen Effekt auf die Wind-katalysierte Translokation von Pipe.

In allen durchgeführten Co-Transfektionen dieser Wind-Mutanten mit Pipe kommt es zu einer GolgiLokalisation von Pipe (1c-3c). Zu 1 c ist zu sagen, dass es sich nicht um eine vollständige Translokation von Pipe in den Golgi handelt. Ein Teil des Pipe-Proteins liegt im Bereich punktueller Strukturen, möglicherweise exit-sites im ER.

Im Gegensatz dazu können Wind Y86L und Y55S nur eingeschränkt den Transport von Pipe in den Golgi katalysieren (s. Abb. 21, 2c, 3c ). Wind Y86S katalysiert dagegen die Translokation von Pipe in den Golgi wie Wind-WT (s. Abb. 21, 4c). 
Daraus lässt sich schliessen, dass die Pipe-Translokation nicht auf dem polaren Charakter von Tyrosin sondern auf dessen Hydrophobizität beruht und dass das Tyrosinpaar Y53 und Y55 eine gemeinsame Oberfläche darstellt, die für die Pipe-Prozessierung erforderlich ist.

Einzelexpression

$$
\text { Wind (Cy3) }
$$
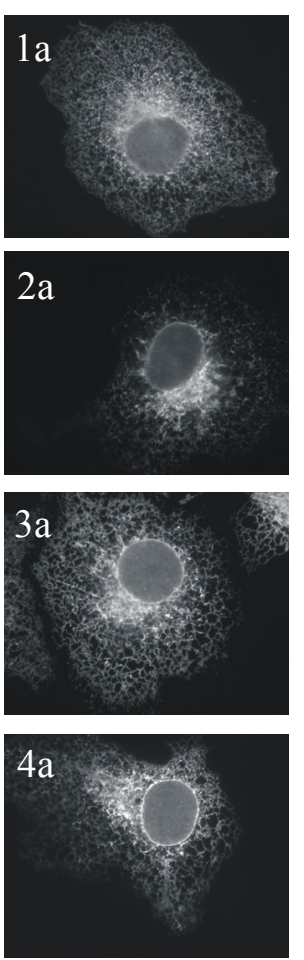

\section{Co-Expression}

Wind (Cy3) Pipe-GFP
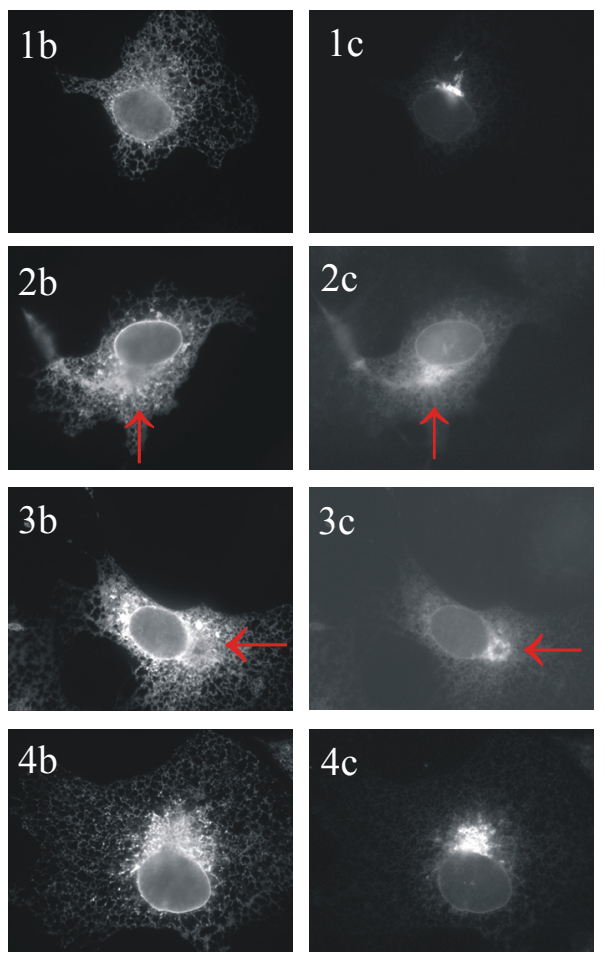

Abb. 21: Wind Y86L und Wind Y55S zeigen eine eingeschränkte, Wind Y86S eine normale Aktivität hinsichtlich der Translokation von Pipe in den Golgi.

In 1a-c ist als Vergleich Wind-WT dargestellt. 1c zeigt die typische Golgi-Verteilung bei Co-Expression von Wind-WT mit Pipe.

In 2a-c, 3a-c und 4a-c sind die Mutationen Wind Y86L, Y55S und Y86S gezeigt. In $2 \mathrm{~b}$ und $3 \mathrm{~b}$ kommt es bei CoExpression mit Pipe zu einer anderen Verteilung in der Zelle verglichen mit Wind-WT (2b, 3b). Es ist eine nur schwache Golgi-Lokalisation zu erkennen, welche mit Pfeilen dargestellt ist (2c, 3c).

Die Mutante Wind Y86S transloziert Pipe in den Golgi in ähnlicher Weise wie Wind-WT (4c).

Die Experimente mit den Mutanten Wind Y86L und Wind Y86S wurden einmal, mit der Mutante Y55S zweimal durchgeführt. 
Weiterhin wurden einige Aminosäuren aus der Umgebung des Tyrosin-Clusters untersucht. So wurden Wind I51 und A52 so mutiert, dass sie eine mögliche hydrophobe Bindung beeinträchtigen sollten. Die Mutanten Wind I51R, I51S und A52S weisen normale Aktivität bezüglich des Pipe-Transports auf. Dies lässt vermuten, dass diese Aminosäuren in Wind nicht an der Interaktion mit Pipe beteiligt sind. In Abb. 22 ist repräsentativ für die genannten Mutationen Wind I52S und sein Effekt auf die Translokation von Pipe dargestellt.

Einzelexpression

$$
\text { Co-Expression }
$$

$$
\text { Wind (Cy3) }
$$$$
\text { Wind (Cy3) }
$$

\section{Pipe-GFP}
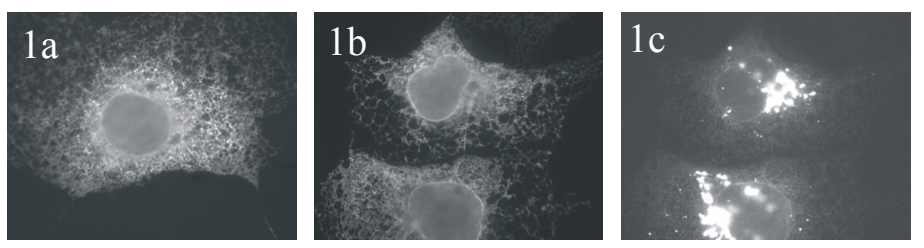

Abb. 22: Aminosäuren um das Tyrosin-Cluster sind nicht an der Interaktion von Pipe beteiligt.

In 1a und 1a sind die Einzel- bzw. Co-Expressionen von Wind I52S dargestellt. Nach Co-Expression von Wind I52S mit Pipe kommt es zur Translokation von Pipe in den Golgi (1c). 


\subsubsection{Die PDI-Dß-Schleife ist nicht an der Interaktion mit Pipe beteiligt}

Tyr86 ist auf einer Schleife in der Wind-Struktur lokalisiert, ebenso wie K84. Diese Schleife (Wind K84, D85, Y86, G87, E88, L89) liegt zwischen 33 und $\alpha 3$ (s. spätere Abb. 29) und hat oftmals Insertionen in Thioredoxin-verwandten Proteinen und könnte eine SubstratBindestelle darstellen (Guddat et al., 1998). Im Gegensatz zu K84D können bei Mutationen von Wind K84 zu S, N, Q keine negativen Effekte bezüglich der Pipe-Prozessierung festgestellt werden (s. Abb. 23). Auch andere Mutationen von Wind in dieser Schleife (D85N, G87S, E88K, E88Q) zeigten keine Veränderung der Pipe-Prozessierung.

Der Austausch von Y86 zu Glu oder Leu zeigen zwar keine Prozessierung von Pipe, jedoch haben Mutationen von Y86 zu Serin oder Phenylalanin keinen Effekt auf die Pipe-Prozessierung.

Bezüglich der Pipe-Prozessierung spielen Interaktion mit spezifischen Aminosäuren dieser PDI-Dß-Schleife offensichtlich keine grosse Rolle. In Abb. 23 ist repräsentativ für die Mutationen von Wind K84 zu S, N, Q die Translokation von Wind K84S gezeigt.

Einzelexpression

Wind (Cy3)

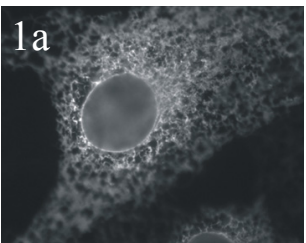

Co-Expression

Wind (Cy3)

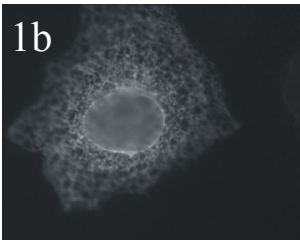

Pipe-GFP

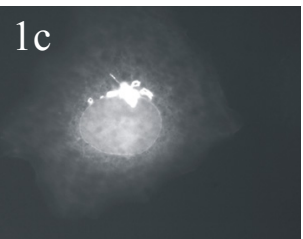

Abb. 23: Aminosäuren in der PDI-Dß-Schleife von Wind sind nicht an der Interaktion von Pipe beteiligt. In Abb. 23, 1a und $1 \mathrm{~b}$ sind die Expressionen in Einzel- bzw. Co-Transfektionen von Wind K84S mit Pipe dargestellt. Bei Co-Transfektion von Wind K84S mit Pipe kann eine Golgi-Verteilung von Pipe beobachtet werden $(1 \mathrm{c})$. 
6.1.2.2. Weder der geladene Dimerspalt noch der Raum in ihm ist essentiell an der Interaktion mit Pipe beteiligt

In weiteren Mutationsstudien sollte die mögliche Beteiligung des geladenen Dimerspalts, der bei der Homodimerisierung von Wind entsteht, an der Substratbindung charakterisiert werden. In diesem Spalt liegen saure Aminosäuren wie D29, D31, E60, E88 und E90, eine weitere am Eingang zum Spalt: nämlich E32. Daher wurden Mutanten generiert, bei denen entweder eine oder zwei saure Aminosäuren (E90R-D29N, E90R-E60A) ausgetauscht wurden. Nur Wind E60Q zeigte eine komplette Blockade des Pipe-Transports, wie bereits in Abb. 17, 2a-c beschrieben. Alle anderen Wind-Mutationen katalysierten die Translokation von Pipe wie Wind-WT. Daraufhin wurde der Effekt von E60Q weiter untersucht. Es wurden weitere Mutationen von Wind E60 zu A, Y und D generiert. Das Ersetzen von E60 durch die kleinere, hydrophobe Aminosäure Alanin oder die polare, grössere Aminosäure Tyrosin hat keinen Einfluss auf die Prozessierung von Pipe. Daher kann man den Schluss ziehen, dass die Aminosäure E60 möglicherweise nicht direkt an der Interaktion mit Pipe beteiligt ist.

Die Mutante Wind D31N ist in der Lage, in co-transfizierten Zellen Pipe in den Golgi zu translozieren, obwohl sie hauptsächlich als Monomer vorliegt (Ma et al., 2003; s. 6.2. Oligomerisierungsexperimente). Daher stellte sich die Frage, ob die noch vorhandene Fähigkeit dieser Mutante, Pipe zu prozessieren, davon abhängt, dass noch eine kleine Menge des Dimers ausgebildet wird. Um diese Frage zu klären, wurde eine Doppel-Mutante von Wind mit D31N generiert. Dazu wurde Wind R41 ausgewählt. Diese Aminosäure trägt entscheidend zur Dimer-Stabilität über hydrophobe Interaktionen entlang seiner Seitenketten bei. R41 wurde zu Serin mutiert. Während R41S allein die Translokation von Pipe in den Golgi katalysiert (Abb. 24, 3c) ist die Doppel-Mutante Wind D31N-R41S dazu nicht in der Lage (s. Abb. 24, 1c). Im Vergleich dazu ist die Einzelmutante Wind D31N in Abb. 24, 2a-c dargestellt, die ebenso Pipe in den Golgi prozessiert (2c). 
Einzelexpression

Co-Expression

Wind (Cy3)
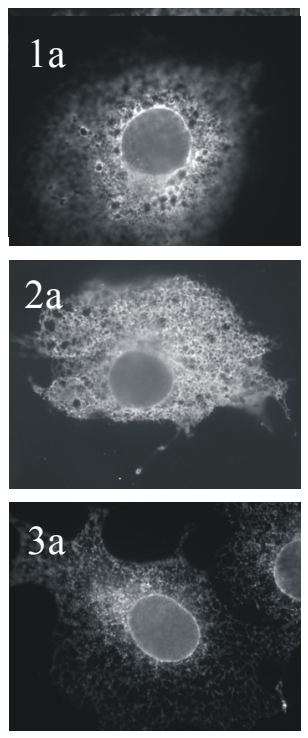

Wind (Cy3)
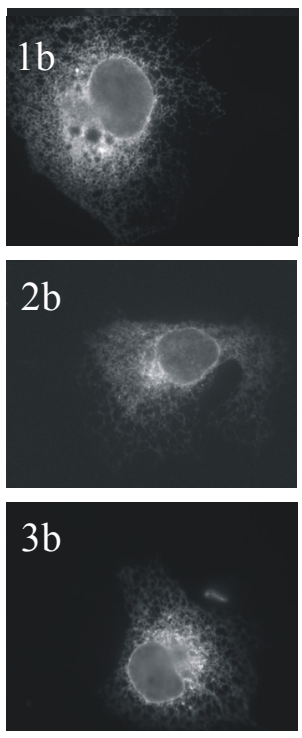

Pipe-GFP
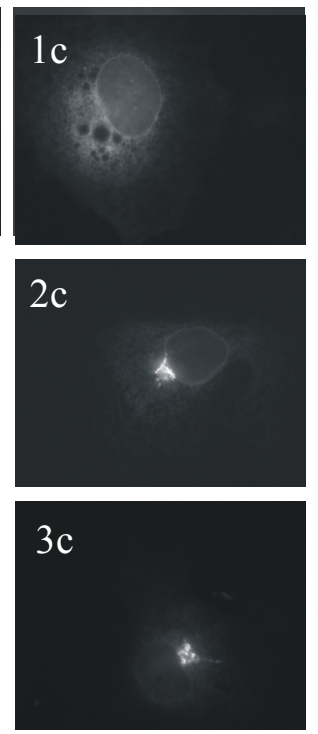

Abb. 24: Die Doppel-Mutante Wind D31N-R41S kann die Pipe-Translokation in den Golgi nicht katalysieren.

In $1 \mathrm{a}$ und $1 \mathrm{~b}$ sind die Einzel- und Co-Transfektion der Mutante Wind D31N-R41S gezeigt. Bei Co-Expression mit Pipe ist die Doppel-Mutante nicht in der Lage, Pipe in den Golgi zu translozieren (1c). In 2a-c ist als Vergleich die Mutante Wind D31N allein gezeigt. Wind D31N allein ist in der Lage Pipe in den Golgi zu prozessieren (2c). In 3a-c ist die Mutante Wind R41S gezeigt, die die Translokation von Pipe in den Golgi katalysiert (3c).

Um herauszufinden, ob der negativ geladene Dimerspalt bzw. der vom Dimerspalt umgebene Raum an der Prozessierung von Pipe beteiligt ist, wurden Punktmutationen in Wind generiert, bei denen die im Spalt gelegenen Aminosäuren entweder durch eine entgegengesetzte Ladung oder durch Aminosäuren völlig verschiedenen Charakters ersetzt wurden (C24S, T25K, C27S, K58S, H59Y, H59R, T63K, E88K). Alle genannten Wind-Mutanten können die PipeTranslokation ähnlich in den Golgi wie Wind-WT katalysieren. Ergänzend zu der Mutante Wind E60Y bedeutet dieses, dass keine spezifischen Interaktionen mit den Seitenketten der im Spalt befindlichen Aminosäure für die Prozessierung von Pipe erforderlich sind. Daraus ist aber nicht auszuschliessen, dass der Dimerspalt für die Prozessierung von Pipe frei zugänglich sein muss. Um diese Frage zu klären, wurden Wind-Mutanten über PCR generiert, die zusätzliche Aminosäuren am N-Terminus von Wind aufweisen. In Wind-WT faltet sich der NTerminus über den Dimerspalt bis zur Mitte dieses Spalts. Durch am N-Terminus eingefügte Aminosäuren sollte der Spalt aufgefüllt werden und so Pipe keinen Zugang mehr gegeben werden. Der Wind N-Terminus wurde um +2 (GS), +4 (HHGS) und +14 Aminosäuren (ERMRGSHHHHHHGS) verlängert. Von dem Konstrukt +14 war zu erwarten, dass es sich 
aufgrund seiner Länge sogar so weit erstreckt, dass die Oberfläche von Wind im Tyr-Cluster nicht mehr zugänglich sein würde. Die Konstrukte +2 und +4 sollten nur den Spalt ausfüllen und nicht auf die Oberfläche herausragen. In Pipe-Translokationsstudien zeigt sich mit den Konstrukten +2 und +4 eine Golgi-Verteilung von Pipe. Bei Verwendung des Konstruktes +14 konnte die Translokation von Pipe in den Golgi nicht mehr katalysiert werden (s. Abb. $25,3 \mathrm{c})$.

Dieses bedeutet zum einen, dass der Raum im Dimerspalt nicht an der Prozessierung von Pipe beteiligt ist, zum anderen, dass das Tyrosin-Cluster zugänglich sein muss, wenn Pipe transportiert werden soll.

Einzelexpression

Co-Expression

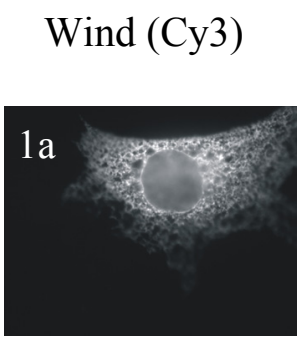

Wind (Cy3)

Pipe-GFP
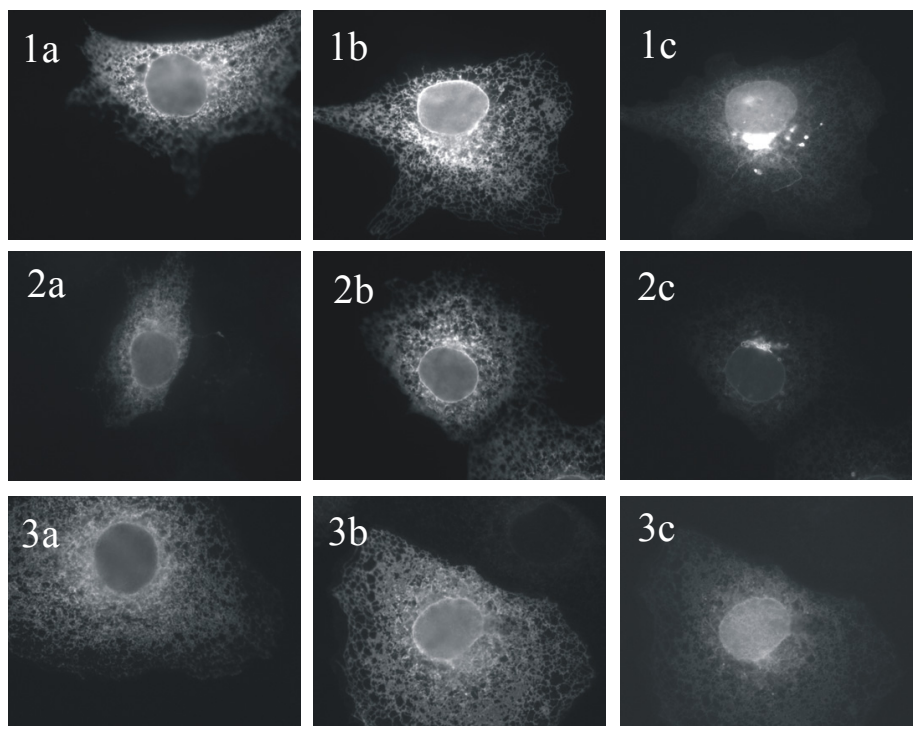

Abb. 25: Effekte der N-terminalen Verlängerung von Wind auf die Translokation von Pipe in COS7Zellen.

In Abb. 25 wird die Transfektion von COS7-Zellen mit den am N-Terminus um +2 (1a-c), +4 (2a-c) oder +14 (3a-c) Aminosäuren verlängerten Wind-Konstrukten gezeigt. Werden COS7-Zellen mit den um +2 oder +4 Aminosäuren verlängerten Konstrukten mit Pipe co-transfiziert, zeigt sich eine Golgi-Lokalisation von Pipe (1c, 2c).

Nach Verlängerung um +14 Aminosäuren kann Wind +14 die Translokation von Pipe in den Golgi in cotransfizierten Zellen nicht mehr katalysieren (3c). 


\subsubsection{Interaktion von Wind mit Pipe findet ohne Beteiligung des flexiblen Linkers statt}

Die Windstruktur beinhaltet einen flexiblen Linker, über welchen die ThioredoxinDomäne kovalent an die D-Domäne gebunden ist. In dieser Linker-Sequenz gibt es vier konservierte Aminosäuren in Wind: Tyr 143, Gly 145, Gly 148 und Cys 149 (s. spätere Abb. 29). Um zu untersuchen, ob die Flexibilität des Linkers für die Pipe-Prozessierung notwendig ist, wurden entweder ein oder sogar beide Glycine jeweils durch die grössere Aminosäure Prolin ausgetauscht (Wind G145P, G148P, G145P-G148P). Für Y143 und C149 erfolgten Mutationen zu Serin (Y143S, C149S).

Keine dieser Mutationen hatte einen Einfluss auf die Pipe-Prozessierung (s. Abb. 26). Dieses bedeutet, dass die Linker-Flexibilität für die Prozessierung von Pipe nicht erforderlich ist. Beispielhaft ist in Abb. 26 die Expression der Doppelmutante Wind G145P-G148P gezeigt.

Einzelexpression Wind (Cy3)

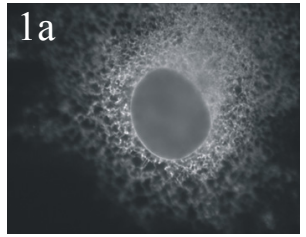

Co-Expression

Wind $(\mathrm{Cy} 3)$

Pipe-GFP
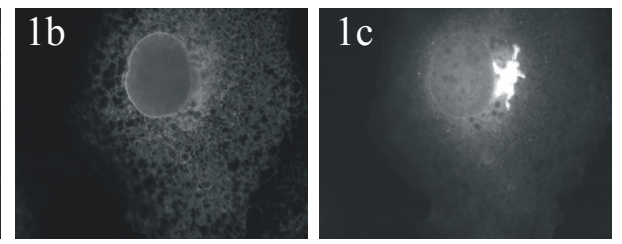

Abb. 26: Der flexible Linker zwischen der Thioredoxin- und der D-Domäne von Wind ist nicht an der Pipe-Prozessierung beteiligt.

In 1a und 1b ist die Einzel- bzw. Co-Transfektion der Doppelmutante Wind G145P-G148P dargestellt. Diese Doppelmutante transloziert Pipe zum Golgi ähnlich wie Wind-WT. (1c).

\subsubsection{Das CTGC-Motiv in Wind ist nicht an der Pipe-Interaktion beteiligt}

Wind besitzt ein CXXC-Tetrapeptid, welches teilweise oberflächlich zugänglich ist und am N-Terminus vor $\beta 1$ im Dimerspalt liegt, ca. $10 \AA$ entfernt von Tyrosin 55. Dieses Tetrapeptid ist nicht in anderen PDI-Dß-Homologen vorhanden. Die Isomerase-Aktivität von PDI-Proteinen ist abhängig von der Anwesenheit des redox-aktiven Tetrapeptids. In Wind besteht dieses Motiv aus den Aminosäuren CTGC. Durch Mutationen der beiden Cysteine zu jeweils Serin sollte untersucht werden, ob Wind redox-aktiv ist. In unserem PipeTranslokationsassay zeigt sich, dass das CTGC-Motiv in Wind nicht für den Pipe-Transport essentiell ist, da Pipe bei Co-Expression mit Wind-STGS in den Golgi transportiert wird (s. Abb. 27). Es fehlt ihm die katalytische Redox- und Isomerase-Aktivität. 


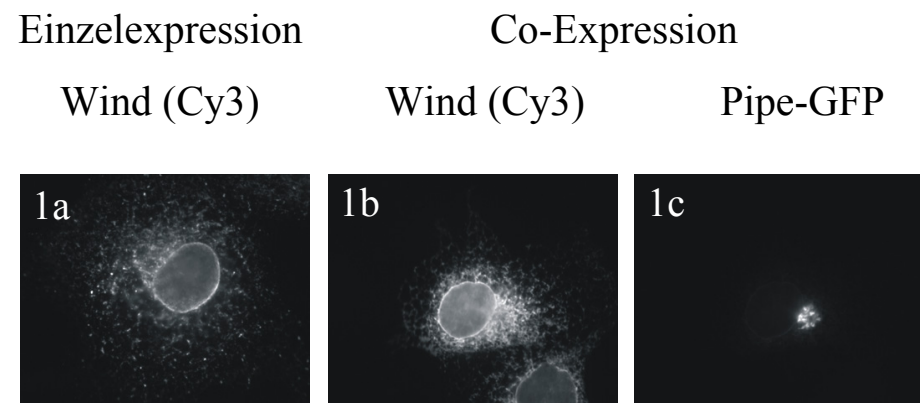

Abb. 27: Das CTGC-Motiv in Wind ist nicht für die Translokation von Pipe erforderlich.

In Abb. 27, 1a-c ist die Expression der Doppelmutante Wind-STGS dargestellt. Die Co-Expression von WindSTGS mit Pipe katalysiert die Translokation von Pipe in den Golgi wie Wind-WT (1c).

\subsubsection{Untersuchung der D-Domäne von Wind bezüglich seiner Bindung an Pipe}

Von den Ergebnissen der Deletionskonstrukte ist bekannt, dass die D-Domäne von Wind allein (Konstrukt ssD*) Pipe nicht transportieren kann (s. Abb. 15, 7a-c). Jedoch kann die D-Domäne von Wind durch die seines Säuger-Homologs ERp28 ersetzt werden (Konstrukt WindABC-ErpD*), wie bereits in Abb. 15, 6a-c gezeigt. Dieses Fusionsprotein katalysiert die Translokation von Pipe in den Golgi wie Wind-WT (s. Abb.28). Dies bedeutet, dass die D-Domäne von Wind auch am Transport von Pipe beteiligt ist. Daraufhin wurden Punktmutationen (Wind E226Q, K229S, E231Q und N237A) in der D-Domäne von Wind durchgeführt.

Alle diese Mutanten katalysierten die Pipe-Translokation in den Golgi in normaler Weise, wie es beispielhaft für Wind E231Q in Abb. 28 gezeigt wird.

Einzelexpression

Wind (Cy3)

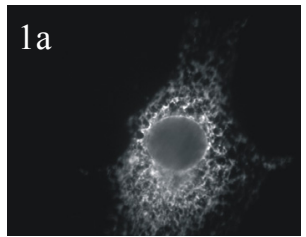

Co-Expression

Wind (Cy3)

Pipe-GFP
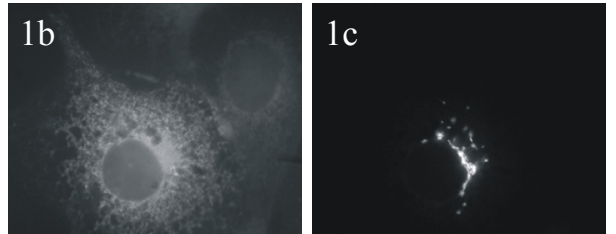

Abb. 28: Die Mutationen konservierter Aminosäuren in der D-Domäne von Wind haben keinen Effekt auf die Prozessierung von Pipe in den Golgi.

Repräsentativ ist in Abb. 28, 1a und 1b die Einzel- und Co-Expression mit Pipe am Beispiel der Mutante Wind E231Q dargestellt. Bei Co-Transfektion mit Pipe ist Wind E231Q in der Lage, Pipe in den Golgi zu translozieren (1c). 


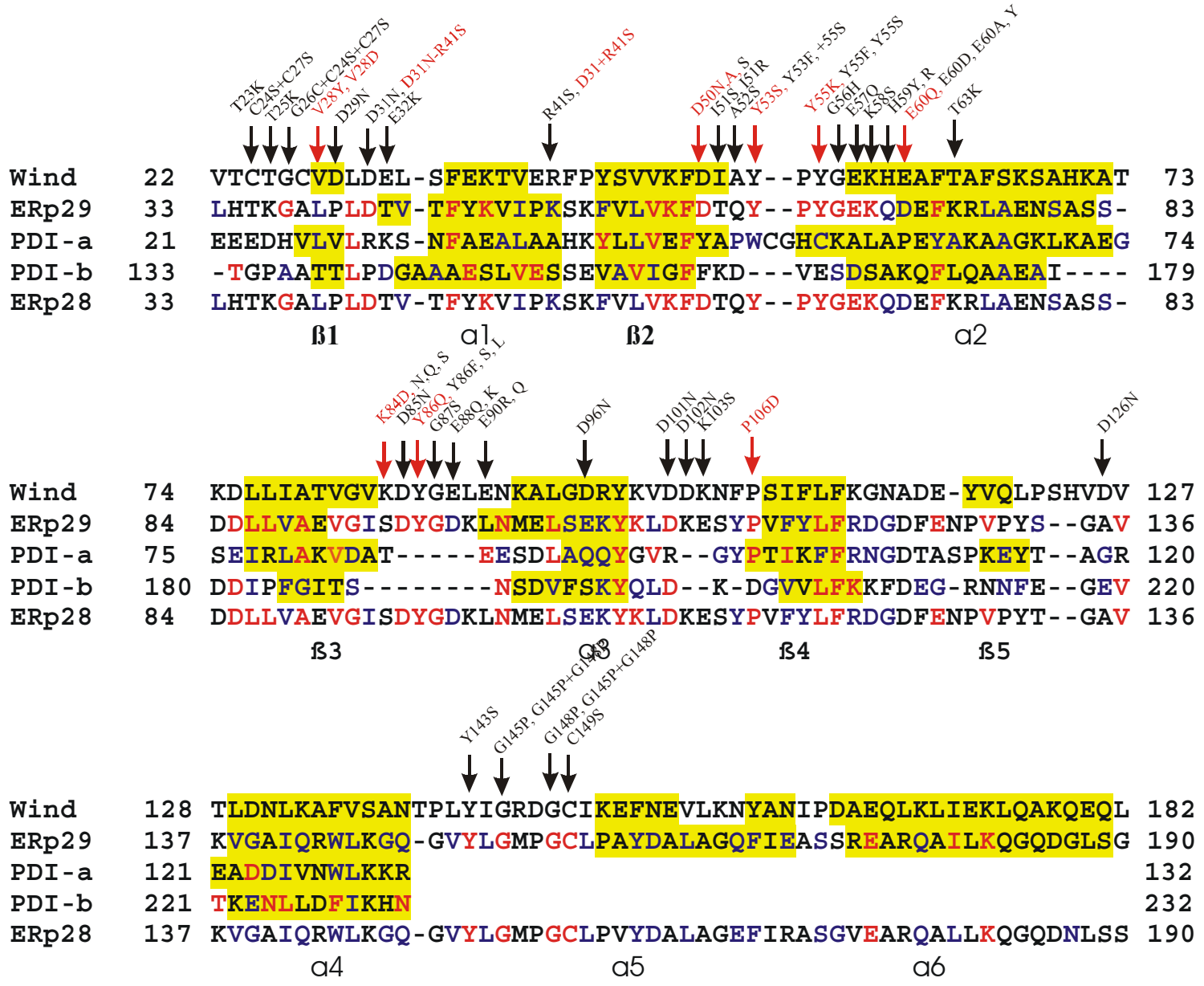

Wind 183 TDPEQQQNARAYLIYMRKIHEVGYDFLEEETKRLLRLKA 221

ERP29 191 VKETDKKWASQYLKIMGKILDQGEDFPASELARISKLIE 229

ERP2 191 VKETQKKWAEQYLKIMGKILDQGEDFPASEMTRIARLIE 229

a7

a8

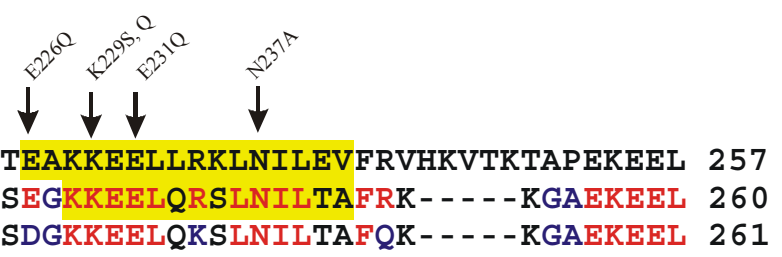

a9

Abb. 29: Sequenzvergleich von Wind mit den a- und b-Domänen von humaner PDI und den Homologen ERp28 (Maus) und Erp29 (Ratte).

Dargestellt sind sämtliche Punktmutationen in Wind, die durchgeführt wurden.

Die Proteinsequenz von Wind ist im Vergleich zu ERp29 (Ratte), ERp28 (Maus) und den a und b-Domänen von humaner PDI dargestellt. Die Strukturelemente ( $\alpha$-Helix und $\beta$-Faltblatt) sind unterhalb gezeigt, die zum jeweiligen Strukturmerkmal gehörenden Aminosäuren sind gelb markiert. Übereinstimmende Aminosäuren sind rot dargestellt, ähnliche in blau. Die teilweise zu ERp29, ERp28 konservierte Insertion in Wind liegt zwischen $\beta 3$ und $\alpha 3$ (PDI-Dß-Schleife). Mutationen in Wind, die rot dargestellt sind, verhindern die Translokation von Pipe in den Golgi. In schwarz dargestellte Mutationen zeigten keinen negativen Effekt auf die PipeProzessierung. 


\subsubsection{Untersuchung der Pipe-Retention}

Bezüglich Pipe sollte herausgefunden werden, auf welche Weise Pipe in Abwesenheit von Wind im ER reteniert wird. Daher wurden verschiedene Pipe-Deletionskonstrukte generiert, die an GFP fusioniert werden.

Wird nur die Transmembrandomäne von Pipe (TM50, AS 1-50) exprimiert, kommt es zu einer Golgi-Verteilung von Pipe (s. Abb. 30, 1a). Wird die Transmembrandomäne mit einem Teil der löslichen Domäne von Pipe exprimiert (TM95, AS 1-95) so kommt es zu einer Lokalisation von Pipe sowohl im Golgi als auch im ER (1b). Bei kürzeren Deletionen (AS 1202, AS 1-252) ist nur noch eine ER-Lokalisation von Pipe zu beobachten (Abb. 30, 1c-d).

\section{Einzelexpression mit Pipe-GFP}
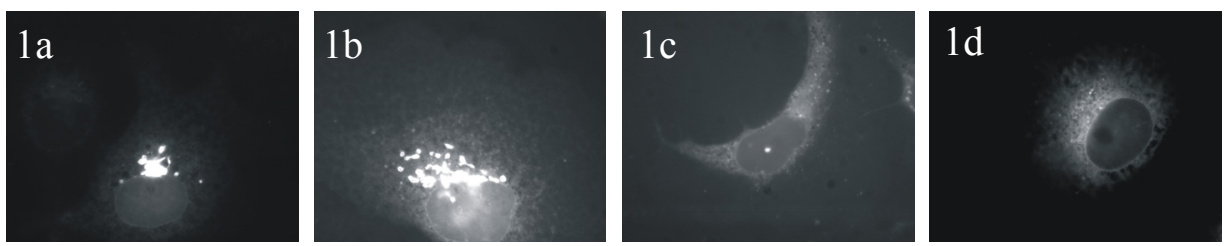

Abb. 30: Transfektion von COS7-Zellen mit verkürzten Pipe-GFP-Fragmenten.

COS7-Zellen wurden transfiziert mit den vom C-Terminus verkürzten GFP-Fusionskonstrukten, welche die Aminosäuren 1-50 umfasst (1a), die Aminosäuren 1-95 (1b), weiterhin AS 1-202 (1c) und AS 1-252 (1d). In 1a ist eine deutliche Golgi-Lokalisation von Pipe TM50 zu erkennen. Beim Konstrukt Pipe TM95 ist bereits eine gemischte Lokalisation in Golgi und ER zu sehen (1b). Wenn geringere Deletionen durchgeführt werden, kommt es zu einer ausschliesslichen ER-Lokalisation (1c, 1d).

Desweiteren sollte untersucht werden, ob die lösliche Domäne von Pipe von Wind transportiert werden kann. Dazu wurde das Konstrukt ssPipe-GFP mit einer Signalsequenz am N-Terminus mit Wind co-transfiziert. Es konnte keine Translokation von ssPipe-GFP in diesem Versuch festgestellt werden (s. Abb. 31, 1c).

Einzelexpression

Co-Expression

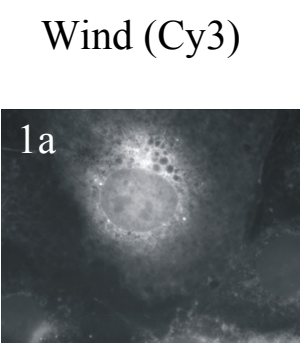

Wind (Cy3)

Pipe-GFP
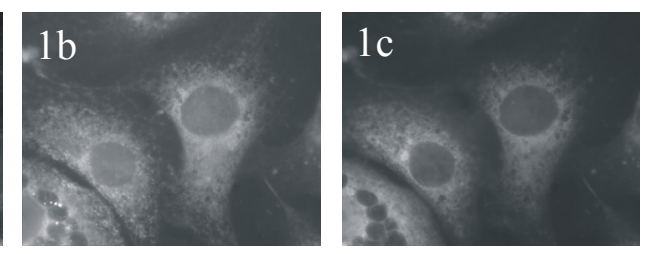

Abb. 31: Die lösliche Domäne von Pipe kann nicht durch Wind-WT transloziert werden, sondern verbleibt im ER.

In 1a-c ist die Expression von der löslichen Domäne von Pipe dargestellt. Die lösliche Domäne von Pipe kann durch Wind nicht in den Golgi transloziert werden (1c). 


\subsection{Oligomerisierungsexperimente}

\subsubsection{Oligomerisierungsexperimente von Wind}

Es wurde bereits gezeigt, dass die Mutante Wind D31N, obwohl hauptsächlich als Monomer vorliegend, immer noch in der Lage ist, Pipe zu prozessieren (Ma et al., 2003, Abb. 24, 2a-c).

Daher stellte sich die Frage, ob die noch vorhandene Fähigkeit dieser Mutante, Pipe zu prozessieren, davon abhängig ist, dass noch ein kleiner Anteil an Dimer ausgebildet wird.

$\mathrm{Zu}$ diesem Zweck wurden in vitro cross-linking Versuche durchgeführt.

Es stellt sich heraus, dass Wind D31N nach separater Expression (20 $\mu \mathrm{g}$ DNA) in COS7Zellen und anschliessendem cross-linking mit DSS als Dimer vorliegt (Abb. 32, Bild 4).

Das gereinigte, rekombinante Protein dagegen lag hauptsächlich als Monomer vor, war nicht stabil und bildete Aggregate.

Daher war es notwendig, Mutanten zu generieren, die auch bei Expression in Zellen als Monomer vorliegen.

Dieses wurde mit den Mutanten Wind V28D und Wind V28Y erreicht.

Beide verhindern vollständig die Dimerisierung von Wind sowohl in vitro als auch in vivo und die Translokation von Pipe in unserem Assay (Daten nicht gezeigt). Jedoch konnte eine signifikante Tendenz zur Aggregation bei diesen Mutanten festgestellt werden. Diese Aggregation könnte bewirkt haben, dass das Protein vom Substrat weg sequestriert wird.

Deshalb wurden weitere Mutanten generiert.

Wir entschieden uns für Wind R41, welches zwischen $\alpha 1$ und $\beta 2$ in der Wind-Struktur lokalisiert ist. Diese Aminosäure trägt entscheidend zur Dimer-Stabilität über hydrophobe Interaktionen entlang seiner Seitenketten bei. R41 wurde zu Serin mutiert.

Die Ergebnisse der cross-linking Experimente sind in Abb. 32 dargestellt. Wind R41S zeigt ein Dimer (Abb. 32, Bild 2), vergleichbar mit dem Wind-WT (Abb. 32, Bild 1). Von der Doppelmutante Wind D31N-R41S war bekannt, dass sie Pipe nicht mehr in den Golgi translozieren kann. Es zeigte sich, dass sie als Monomer vorliegt (Abb. 32, Bild 3). Im Unterschied zu V28D und V28Y zeigen sich deutlich weniger Aggregate.

Um auszuschliessen, dass die durchgeführten Mutationen in Wind, die die Translokation von Pipe in den Golgi bei Co-Expression unterbinden, Einfluss auf die Struktur des Wind-Proteins haben, wurden diese Mutationen ebenso auf ihren Oligomerisierungszustand hin überprüft.

In Abb. 32, Bild 5 wird deutlich, dass auch Wind Y53S als Dimer vorliegt.

Ebenso als Dimer liegen Wind Y86Q (6), Y55K (7) und P106D (8) vor. Alle genannten Mutationen in Wind bilden ein Dimer aus, dieses ist jedoch unerwarteterweise nur ein geringer Anteil im Vergleich zum Monomer Wind. Von ERp28 z.B. ist bekannt, dass es fast zu $100 \%$ als Dimer vorliegt (Experimente von Dr. D. Ferrari).

In Abb. 32, Bild 9 ist beispielhaft für weitere durchgeführte Mutationen von D50 die Mutante Wind D50S gezeigt, welche ebenso als Dimer vorliegt. Wind D50S katalysierte teilweise den Transport von Pipe in den Golgi (Abb. 19, 2c). Wind D50A konnte diese Translokation nicht katalysieren, liegt jedoch auch als Dimer vor.

Aus diesen Ergebnissen wird ersichtlich, dass ein Wind-Dimer vorliegen muss, um die Prozessierung von Pipe gewährleisten zu können. 

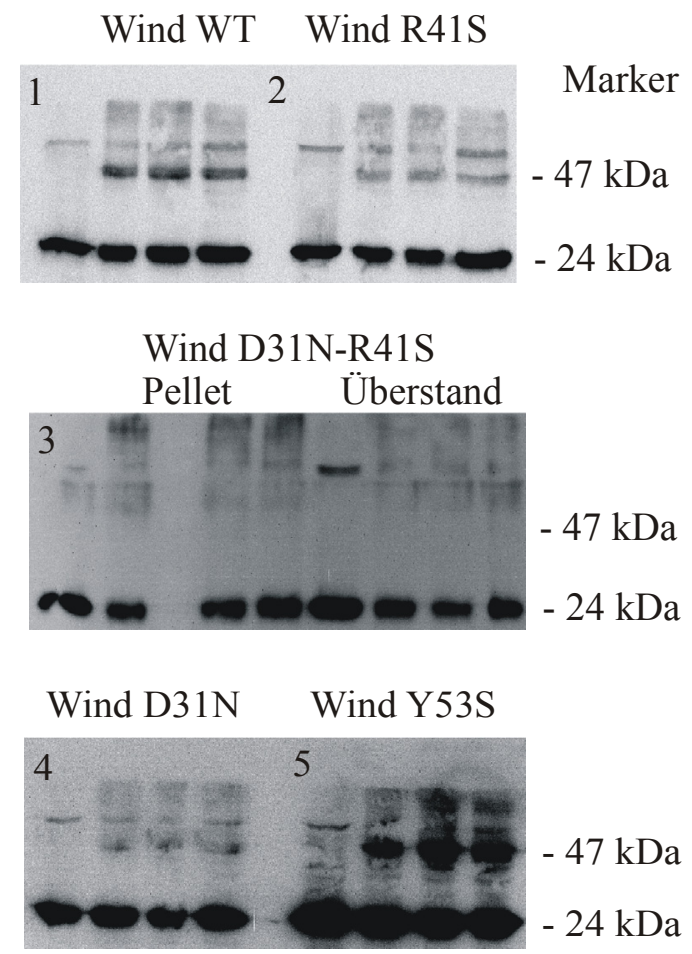

\section{Wind Y86Q}

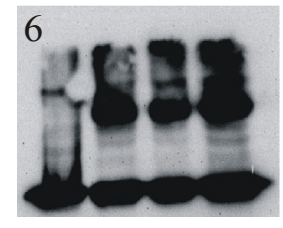

$$
\begin{aligned}
& -47 \mathrm{kDa} \\
& -24 \mathrm{kDa}
\end{aligned}
$$

Wind Y55K

7
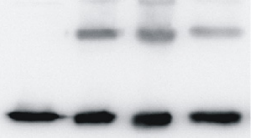

- $47 \mathrm{kDa}$

$-24 \mathrm{kDa}$

Wind P106D

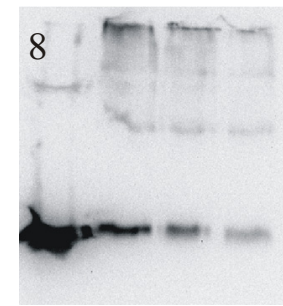

$-47 \mathrm{kDa}$

- $24 \mathrm{kDa}$

\section{Wind D50S}

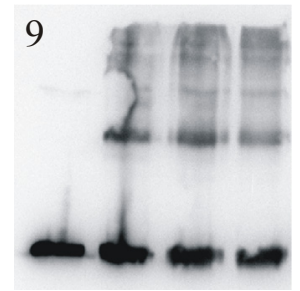

- $47 \mathrm{kDa}$

$-24 \mathrm{kDa}$

Abb. 32: Proteinnachweis auf Western Blots nach cross-linking verschiedener Wind-Mutanten, die die Pipe-Translokation in den Golgi in transfizierten COS7-Zellen verhindern.

Bild (1) zeigt Wind-WT nach cross-linking mit DSS. In der jeweils linken Spur ist die Kontrolle zu sehen, ohne 
Zugabe von cross-linker. Spuren 2-4 zeigen Proben, die jeweils mit cross-linker behandelt (0,25 mM, 0,5 mM und $2 \mathrm{mM}$ ) sind. Wind-Protein wurde mit spezifischen Antikörpern nachgewiesen und liegt zum Teil als Dimer bei ca. $48 \mathrm{kDa}$ vor. Als Grössenstandard dient für $24 \mathrm{kDa}$ das Protein $\beta$-Laktoglobulin, für $47 \mathrm{kDa}$ dient Ovalbumin.

In Bild (2) ist die Mutante Wind R41S nach cross-linking dargestellt, welche ebenso teilweise als Dimer sichtbar wird.

Bild (3) zeigt die Doppelmutante D31N-R41S. Aufgetragen sind auf diesem Blot die cross-linking-Lysate des Pellets (links) und des Überstandes (rechts). In beiden Proben ist nur das Monomer bei ca. $24 \mathrm{kDa}$ zu sehen. In dieser Doppelmutante kommt es nicht zur Ausbildung des Dimers.

Bild (4) zeigt die Mutante Wind D31N, Bild (5) Wind Y53S. Beide liegen teilweise als Dimer vor.

Bild (6) zeigt die Mutante Wind Y86Q, welche nach cross-linking ebenso zum Teil als Dimer nachgewiesen wurde.

Bilder (7), (8) und (9) zeigen Wind Y55K, Wind P106D und Wind D50S nach cross-linking teilweise als Dimer von erwarteter Grösse von $24 \mathrm{kDa}$.

Sämtliche hier gezeigten Proben sind auf $12 \%$-SDS-Gelen aufgetrennt und mit Anti-Wind Primärantikörper nachgewiesen. 


\subsubsection{Oligomerisierung von Pipe}

Ebenso wurde Pipe auf seinen Oligomerisierungszustand hin überprüft. Pipe bildet ein Oligomer nach cross-linking mit DSS (Abb. 33, 1). Um auszuschliessen, dass dieser Oligomerisierungszustand von Pipe nicht durch das Fusionsprotein GFP verursacht wird, wurde ein anderes Konstrukt generiert, welches ein Myc-tag am C-Terminus von Pipe aufwies. Dieses Konstrukt konnte jedoch keinen Aufschluss darüber geben, ob Pipe an sich aggregiert oder aufgrund des GFP-Fusionsproteins als Oligomer vorliegt. Dieses könnte daran gelegen heben, dass die zur Verfügung stehenden Myc-Antikörper nicht spezifisch genug waren (Daten nicht gezeigt). Zudem wurde mit einer 3-fach höheren DNA-Konzentration transfiziert, um überhaupt Protein nachweisen zu können.

Daher wurde eine andere Methode angewendet: das Konstukt Pipe-GFP wurde im GFPBereich mutiert (A206K). Durch diese Mutation im GFP-Bereich kann die Möglichkeit von Spontanassoziationen von GFP-Molekülen verhindert werden (Zacharias et al., 2002).

Cross-linking Experimente mit dieser GFP-Mutation in Pipe zeigen eine ähnliche Aggregation der Pipe-Mutante (Abb. 33-2) wie Pipe-WT (Abb. 33-1). Daraus lässt sich schliessen, dass die Aggregation von Pipe nicht durch das GFP verursacht wird, sondern Pipe selbst als ein Oligomer vorliegt.

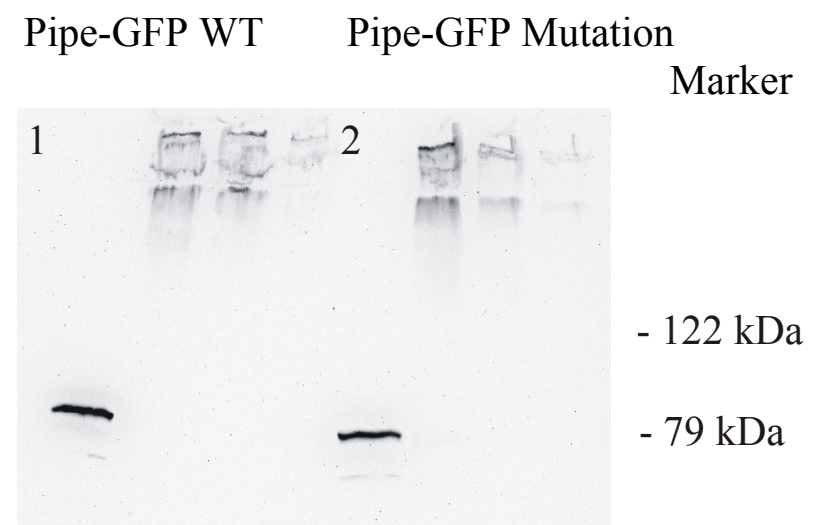

Abb. 33: Oligomersierung von Pipe. Unter 1 ist der cross-linking-Versuch mit WT Pipe-GFP gezeigt, unter 2 der gleiche Versuch mit der eingefügten Mutation im GFP (A206K).

In der jeweils linken Spur ist Pipe-GFP bzw. Pipe-GFP-Mutation als Kontrolle ohne cross-linker aufgetragen. In den Spuren 2-4 wurden für beide Versuche folgende Konzentrationen an cross-linker DSS eingesetzt: 0,25 mM, $0,5 \mathrm{mM}$ und $2 \mathrm{mM}$. Sämtliche Proben sind auf $7 \%$-igen SDS-Gelen aufgetrennt. Als Referenzproteine dienten Rinderalbumin $(79 \mathrm{kDa})$ und $\beta$-Galaktosidase $(122 \mathrm{kDa})$. 


\section{Diskussion}

Bis vor kurzem gab es keine exakte Beschreibung von Substrat-Bindestellen in PDI und PDI-verwandten Proteinen. Dieses ist teilweise auf die Multidomänenstruktur dieser Proteine zurückzuführen (Ferrari und Söling, 1999). In einigen Arbeiten wurde postuliert, dass mehrere Domänen von PDI an der Substratbindung beteiligt sein könnten (Klappa et al., 1998). Weiterhin besteht die Schwierigkeit in der Trennung von Redox-Aktivität und Chaperon-Aktivität (Freedman et al., 2002).

Mit den in dieser Arbeit durchgeführten Experimenten konnte eine Bindestelle des WindProteins, einem PDI-Dß-Protein, für sein Substrat Pipe identifiziert werden.

Die Ergebnisse zeigen, dass Wind sowohl die Thioredoxin- als auch die D-Domäne benötigt, um Pipe zu binden und in den Golgi zu translozieren.

In der Thioredoxin-Domäne von Wind wurde mittels Punktmutationen eine Bindestelle für Pipe identifiziert (s. S. 55). Diese besteht aus einer hydrophilen Tasche um die Aminosäure D50 und beinhaltet ein oberflächlich gelegenes Cluster von zwei Tyrosinen (Y53, Y55), welches vor der $\alpha$-Helix 2 lokalisiert ist. Ein drittes Tyrosin (Y86) liegt in der Schleife zwischen $\beta 3$ und $\alpha 3$. Dieses Tyrosin ist aber, wie andere Aminosäuren der Schleife, nicht essentiell für die Interaktion mit Pipe (s. S. 61). In anderen Thioredoxin-Proteinen kommen in dieser Schleife Insertionen vor. Für E. coli DsbA z.B. wird postuliert, dass diese Insertion für die Substraterkennung oder -bindung notwendig ist (Guddat et al., 1998). So könnte die PDIDß-Schleife zwar für die Substratspezifität, aber nicht für die Substratbindung erforderlich sein.

Die Wichtigkeit dieser Tyrosine bei der Interaktion mit Pipe wird durch Versuche mit den verlängerten Wind-Konstrukten bestätigt (s. S. 64). Die um +2 und +4 Aminosäuren verlängerten Konstrukte, die den Dimerspalt auffüllen sollten, zeigten keinen Einfluss auf die Pipe-Prozessierung. Durch das um +14 Aminosäuren verlängerte His-Konstrukt war der PipeTransport dagegen unterbunden. Der längere tag streckt sich bei diesem Konstrukt aus dem Spalt hinaus und verhindert die Zugänglichkeit für Pipe im Bereich des Tyrosin-Clusters, welches sich in einer fehlenden Translokation von Pipe äussert. Bezüglich der Tyrosine handelt es sich eher um einen hydrophoben Effekt als um eine Folge ihres polaren Charakters, wie durch Mutation der Tyrosine zu Phenylalanin erkennbar wurde (s. S. 58).

Dieses Tyrosin-Cluster stellt eine wesentliche Bindestelle für Pipe dar. Der flexible Linker, die Ladung im Dimerspalt sowie der Raum im Dimerspalt sind nicht an der Interaktion mit 
Pipe beteiligt. Weiterhin ist das CTGC-Motiv in Wind in Bezug auf Pipe-Translokation und Redox-Funktion inaktiv (s. S. 66).

Wind Y53 und Wind Y55 gehen eine stabilere Bindung mit Pipe ein als Wind-WT. Diese Assoziation ist scheinbar so stabil, dass sowohl Chaperon als auch Substrat einer gleichzeitigen Degradation unterliegen (MG 132-Experimente). Dieser starke Bindungseffekt wird auch in einem anderen, von Dr. D. Ferrari durchgeführten Experiment deutlich: synthetische Peptide, die das gesamte Protein Pipe umfassen, wurden in dot blots hinsichtlich der Bindung mit Wind-WT und der Mutante Wind Y55K getestet. Auf diesem Blot sind 177 verschiedene synthetische Peptide von Pipe mit einer Länge von je 13 Aminosäuren vom Hersteller (Jerini) aufgetragen, welche den luminalen Bereich von Pipe abdecken. Jedes folgende Peptid war um 2 Aminosäuren zum vorhergehenden versetzt. Diese Membran wurde für $12 \mathrm{~h}$ entweder mit 5,6 $\mu \mathrm{M}$ Wind-His oder 1,7 $\mu \mathrm{M}$ Wind-His Y55K inkubiert. Nach dieser Vorinkubation erfolgten die Inkubationen mit dem Anti-Wind Primärantikörper und dem Sekundärantikörper wie im Western Blot. Die Bindungsmuster von Peptid-gebundenem Wind-WT und der Mutante Wind Y55K waren sehr ähnlich. Die Mutante Y55K hat jedoch wesentlich stärker gebunden und zeigte noch zusätzliche Bindungsstellen (s. Abb. 34). Dieses könnte bedeuten, dass Pipe über eine Vielzahl von Bindestellen für Wind verfügt. Da es bisher keine Kristallstruktur von Pipe gibt, kann man ohne zusätzliche Versuche keine Aussage darüber treffen, ob die Aminosäuren dieser möglichen Bindestellen an der Oberfläche des Proteins lokalisiert und an der Interaktion mit Wind beteiligt sind.

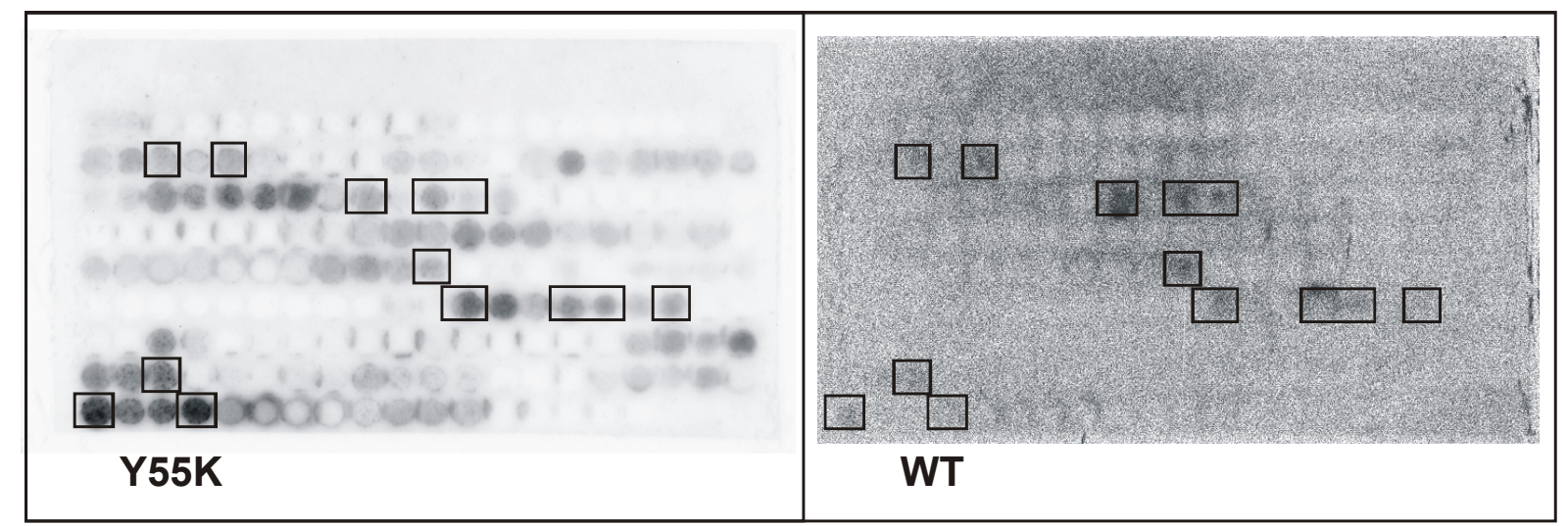

Abb. 34: Wind Y55K bindet an synthetische Pipe-Peptide mit verschiedener Stärke.

Links ist ein Blot mit Wind Y55K, rechts mit Wind-WT dargestellt. In Kästchen sind die Interaktionen dargestellt, die sowohl in Wind Y55K als auch Wind-WT auftreten.

Ausgehend von diesem Blot wurden die Peptide analysiert, an die Wind binden konnte.

Auffällig ist, dass diese Peptide hinsichtlich ihrer Sequenz sehr unterschiedlich sind (Abb. $35)$. 


\begin{tabular}{lcc} 
& Peptidsequence & Pipe Aminosäuren \\
\hline 1. & VRRNFTNEIEFYQFCRQRLHKQY & Val359-Tyr381 \\
2. & NTTLSVLEKYVPRFFEGVRDIYATS & Asn311-Ser335 \\
3. & MELLRRLSERNNFQF & Met129-Phe143 \\
4. & FNRVPKVGSQTFMELLRRLSERN & Phe117-Asn139 \\
5. & VEGIGDHRRQSLFFCGHDYECTPFN & Val261-Asn285 \\
6. & YVRAPWYFVERKAAFPDLPLP & Tyr213-Pro233 \\
7. & SVFIKHVCFTNFTKFNLPRPIYLNVVR & Ser175-Arg201 \\
8. & QFCRQRLHKQYLAAHLPQRIITD & Gln371-Asp393 \\
9. & PFNTVGALERAKF & Pro283-Phe295 \\
10. & DINTLHGTYQYLKSTGQMSSLNV & Asp79-Leu99 \\
11. & NNTRKAQMELVFFNRVPKVGSQT & Asn105-Thr127
\end{tabular}

Abb. 35: Die Bindung von Wind Y55K an die synthetischen Peptide von Pipe in Abhängigkeit ihrer Bindungsaffinität.

Peptide, die an das C-terminale Wind (Wind-His) binden, sind fett gedruckt.

In gelb ist die Übereinstimmung dieser Peptide dargestellt. Die Peptide sind in der Reihnenfolge ihrer Bindungsstärke für Wind Y55K angeordnet.

Dabei konnte lediglich ein Bereich von 2 aufeinanderfolgenden Aminosäuren (Phenylalanin und Tyrosin) übereinstimmend festgestellt werden, der an der Bindung zu Wind beteiligt sein könnte. Vier von den fünf Wind Y55K sehr stark bindenden Peptidsequenzen sind unter den ersten sechs am stärksten bindenden Peptiden. Für PDIp wurde gezeigt, dass es an Peptide, die ein einzelnes Tyr oder Trp aufweisen, binden kann (Ruddock et al., 2000).

Desweiteren wurde die Mutante Wind Y53S kristallisiert (Sevvana et al., Manuskript in Vorbereitung). Die Struktur dieser Mutante ist mit der von Wind-WT praktisch identisch, welches die Aussage unterstützt, dass Pipe stabil und spezifisch an Wind Y53S bindet und nicht aufgrund einer mutationsbedingten geänderten Struktur von Wind.

Eine mögliche Peptid-Bindestelle wurde kürzlich in der $b^{\prime}$-Domäne des humanen PDIProteins beschrieben (Pirneskoski et al., 2004). In dieser Arbeit wird eine hydrophobe Tasche beschrieben, die die Aminosäuren Leu242, Leu244, Phe258 und Ile272 umfasst. Mutationen dieser Aminosäuren führen zum Bindungsverlust für das synthetische Substrat $\Delta$-Somatostatin. Den grössten Effekt dabei hat der Austausch I272W. Nach Durchführen eines Sequenzvergleichs mit dem humanen Protein PDI entsprechen die Aminosäuren L242 und L244 den Aminosäuren Lys48 und Asp50 im Wind-Protein. Wie ich gezeigt habe, führten Mutationen von D50 zu A und N zu einem Verlust der Substrat-Bindung in Wind, welches sich in der unterbundenen Translokation von Pipe in den Golgi äussert.

Die Aminosäuren Phe258 und Ile272 in der PDI-Sequenz entsprechen den Positionen Phe62 und Thr80 im Wind-Protein. Da beide nicht an der Oberfläche des Wind-Proteins liegen, ist es äusserst unwahrscheinlich, dass sie an der Interaktion mit Pipe beteiligt sind. 
Für PDIp wurde gezeigt, dass die Substratbindung über eine einzelne Aminosäure, nämlich Tyr oder Trp stattfinden kann (Klappa et al., 2001).

Ergänzend zu der Thioredoxin-Domäne gibt es eine zweite Bindestelle für Pipe in der DDomäne (Ergebnisse von Dr. D. Ferrari, Manuskript eingereicht, s. Abb. 36 a u. b). Dabei handelt es sich um die Aminosäuren E212, R215, R218, L219 und L232. Dies bestätigt die Ergebnisse meiner Deletionsversuche der D-Domäne im Wind-Protein. Die D-Domäne von Wind allein kann Pipe nicht in den Golgi translozieren, ist aber durchaus essentiell für die Prozessierung von Pipe. Bisher gibt es nur wenige Erkenntnisse über die Funktion der DDomäne. So wurde von Monnat et al. (2000) beschrieben, dass die D-Domäne in Dictyostelium discoideum der KDEL-unabhängigen Retention im ER dient. Weiterhin kann man feststellen, dass aufgrund der Tatsache, dass die Domäne von Wind durch die seines Säuger-Homologs ersetzt werden kann, funktionelle Übereinstimmungen zwischen diesen Proteinen bestehen. Die Bindung von Pepiden scheint ein gemeinsames Merkmal bei Mitgliedern der PDI-D-Familie zu sein.

Für Wind gibt es Hinweise, dass die D-Domäne in Wind an dessen Retention im ER beteiligt ist (Experimente Dr. C. Guo). Es lässt sich nachweisen, dass Wind mit einer durch Mutation erzeugten N-Glykosylierungsstelle in der D-Domäne ER-typisch glykosiliert wird ohne dass es nachfolgend zu einer Golgi-typischen Modifikation des Glykananteils kommt.
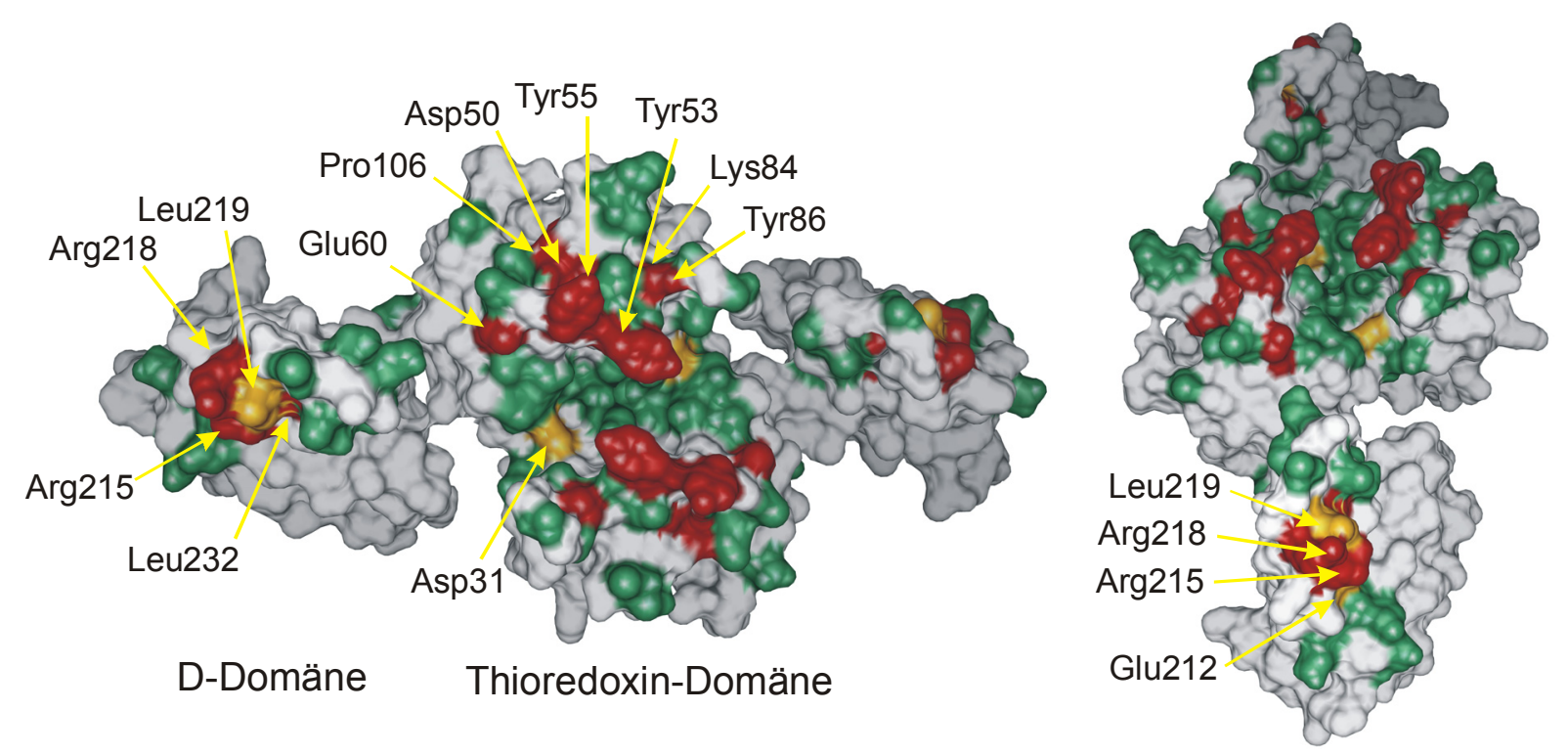

Abb. 36 a u. b: Struktur des Wind-Dimers mit durchgeführten Punktmutationen.

Abb. 36a zeigt in rot alle Punktmutationen, die einen negativen Effekt auf die Pipe-Prozessierung haben. In grün sind durchgeführte Punktmutationen in Wind dargestellt, die die Translokation von Pipe nicht katalysieren.

In gelb sind die Mutanten Wind D31 und L219, die allein keinen Effekt auf die Pipe-Prozessierung haben, zusehen. 
In Abb. 36b ist die Bindungsstelle in der D-Domäne von Wind separat dargestellt. Das Wind-Molekül ist um $180^{\circ}$ gedreht. Farbcode wie in Abb. 36a.

Wind muss für eine Interaktion mit Pipe als Dimer vorliegen. Dieses wurde in Cross-linking Experimenten mit den Mutanten Wind D50S, Y53S, Y55K, Y86Q und P106D, D31N-R41S nachgewiesen (s. S. 69). So zeigte sich, dass die Doppelmutante Wind D31N-R41S die Translokation von Pipe in den Golgi nicht katalysiert. In Cross-linking-Experimenten mit DSS liegt die Doppelmutante ausschliesslich als Monomer vor.

Es wurde eine weitere Mutante generiert, in der in die monomerische Mutante Wind D31N-R41S die Mutation Wind Y55K eingefügt wurde (Wind D31N-R41S-Y55K). Mit dieser Dreifachmutante sollte herausgefunden werden, ob sie ebenso eine stabile Bindung mit Pipe eingeht, wie die Einzelmutante Wind Y55K. Sowohl Wind D31N-R41S als auch Wind Y55K waren nicht in der Lage, Pipe in den Golgi zu prozessieren. Bei der Dreifachmutante kam es hauptsächlich zu einer ER-Verteilung bei Co-Expression mit Pipe und zu einem sehr geringen Teil im Golgi. Das Expressionsniveau dieser Mutante war jedoch vergleichbar mit dem der Doppelmutante. Im Unterschied zu Wind Y55K war keine Abnahme der Menge von Wind-Protein erkennbar. Dieses deutet darauf hin, dass Wind D31N-R41S-Y55K nicht stabil an Pipe bindet, welches bedeuten kann, dass das Monomer nicht wesentlich an Pipe binden kann.

Die Mutante Wind D50N verhinderte zwar den Transport von Pipe in den Golgi, konnte aber nicht in die Auswertung aufgenommen werden, da es bei dieser Mutante nur partiell zur Abspaltung der Signalsequenz kam (s. Abb. 37).

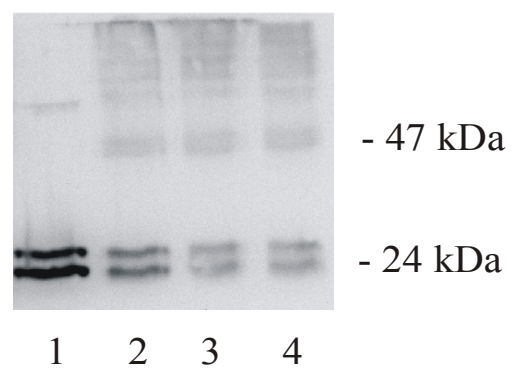

Abb. 37: Oligomerisierungszustand von Wind D50N.

In Abb. 36 ist die Mutante Wind D50N nach cross-linking dargestellt. Spur 1 zeigt Wind D50N ohne crosslinking als Monomer. Es kommt zu einer schwachen Ausbildung des Dimers (Spuren 2-4), bei Behandlung mit dem Cross-linker DSS (0,25 mM, 0,5 mM und $2 \mathrm{mM})$.

Auffällig ist hierbei, dass Wind D50N neben dem Monomer bei 24 kDa eine zusätzliche Bande aufweist.

Bezüglich Pipe konnte gezeigt werden, dass das Fusionsprotein Pipe-GFP an sich oligomerisiert und dass dieses nicht aufgrund der Fusion mit GFP stattfindet. 
Es konnte bisher jedoch keine Interaktion von Wind mit Pipe auf Proteinebene (Western Blot) nachgewiesen werden. Dieses war auch nicht durch Fluoreszenz Resonanz Energie TransferMessungen (FRET) möglich. Ein Grund dafür könnte sein, dass es sich bei der Interaktion von Wind mit Pipe um eine sehr schnelle Interaktionskinetik mit hoher „off-rate“ handelt. Daher sollen FRET-Versuche mit der Windmutante Y55K durchgeführt werden, die eine stabile Bindung mit Pipe eingeht.

Desweiteren sind Transfektionsversuche mit den Konstrukten WindABC-KEEL und WindABC zu wiederholen, um herauszufinden, ob es sich tatsächlich in beiden Fällen um eine ähnliche ER-Verteilung dieser Wind-Konstrukte handelt oder ob Wind sekretiert wird. Dieses könnte mit dem Translations-Hemmer Cycloheximid untersucht werden. Nach Transfektion der Zellen mit den Konstrukten WindABC-KEEL und WindABC und deren Expression könnten die Zellen mit Cycloheximid behandelt und das zeitabhängige Verschwinden der Proteine aus dem ER in der Immunfluoreszenzmikroskopie untersucht werden. Dieser Versuch könnte ebenso mit einer grösseren Zellmenge durchgeführt werden. Dabei würde das Inkubationsmedium auf Sekretion der mutierten Proteine untersucht werden.

Die Ergebnisse dieser Arbeit können über die Funktion von ERp28 und anderen PDIProteinen Aufschluss geben. 


\section{Literatur}

Andersen, C.L., Matthey-Dupraz, A., Missiakas, D. und Raina, S. (1997)

A new Escherichia coli gene, dsbG, encodes a periplasmic protein involved in disulphide bond formation, required for recycling $\mathrm{DsbA} / \mathrm{DsbB}$ and $\mathrm{DsbC}$ redox proteins. Mol Microbiol. (1):121-32.

Bader, M., Muse, W., Zander, T. und Bardwell, J. (1998) Reconstitution of a protein disulfide catalytic system. J. Biol. Chem. 273(17):10302-7.

Bennett, C.F., Balcarek, J.M., Varrichio, A. und Crooke, S.T. (1988) Molecular cloning and complete amino-acid sequence of form-I phosphoinositide-specific phospholipase C. Nature 234, 268-270.

Bergeron, J.J.M., Brenner, M.B., Thomas, D.Y. und Williams, D.B. (1994) Calnexin: A membrane-bound chaperone of the endoplasmic reticulum. Trends in Biochemical Sciences 19, 124-128.

Bjelland, S. (1987) Tissue distribution and molecular heterogeneity of bovine thiol:protein-disulphide oxidoreductase (disulphide interchange enzyme). Comp. Biochem. Physiol. B. 87, 907-914.

Bradford, M.M. (1976) A rapid and sensitive method for the quantitation of microgram quantities of protein utilizing the principle of protein-dye binding. Anal. Biochem. 72, 248-254.

Chapman, R., Sidrauski, C. und Walter, P. (1998) Intracellular signalling from the endoplasmic reticulum to the nucleus. Annu. Rev. Cell Dev. Biol. 14:459-85

Chivers, P.T., Laboissière, M.C.A. und Raines, R.T. (1996) The CXXC motif: imperatives for the formation of native disulfide bonds in the cell. Embo J. 15, 26592667.

Cunnea, P.M., Miranda-Vizuete, A., Bertoli, G., Simmen, T., Damdimopoulos, A.E., Hermann, S., Leinonen, S., Huikko, M.P., Gustafsson, J.A., Sitia, R. und Spyrou, G. (2003) ERdj5, an endoplasmic reticulum (ER)-resident protein containing DnaJ and thioredoxin domains, is expressed in secretory cells or following ER stress. $\mathbf{J}$ Biol Chem. 10;278(2):1059-66.

Demmer, J., Zhou, M.C. und Hubbard, M.J. (1997) Molecular cloning of ERp29, a novel and widely expressed resident of the endoplasmic reticulum. FEBS Lett. 402, 145-150.

Desilva, M.G., Lu, J., Donadel, G., Modi, W.S., Xie, H., Notkins, A.L. und Lan, M.S. (1996) Characterisation and chromosomal localisation of a new protein disulfide isomerase, PDIp, highly expressed in human pancreas. DNA Cell Biol. 15, 9-16.

Ferrari, D.M., Nguyen, Van P, Kratzin, H.D. und Söling, H.D. (1998) ERp28, a human endoplasmic-reticulum-lumenal protein, is a member of the protein disulfide isomerase family but lacks a CXXC thioredoxin-box motif. Eur $\mathrm{J}$ Biochem. 1;255(3):570-9. 
Ferrari, D.M. und Söling H.D. (1999) The protein disulphide-isomerase family: unravelling a string of folds. Biochem J. 339 (Pt 1):1-10.

Frand, A.R. und Kaiser, C.A. (1998) The ERO1 gene of yeast is required for oxidation of protein dithiols in the endoplasmic reticulum. Mol. Cell 1, 161-170.

Freedman, R.B., Hirst, T.R. und Tuite, M.F. (1994) Protein disulfide isomerase: Building bridges in protein folding. Trends Biochem. Sci. 19, 331-336.

Freedman, R.B. (1994) Protein folding. Folding helpers and unhelpful folders. Curr. Biol. 4, 933-935.

Freedman, R.B., Klappa, P. und Ruddock, L.W. (2002) Protein disulfide isomerases exploit synergy between catalytic and specific binding domains. EMBO Rep. 3(2):136-40.

Freskard, P.O., Bergenhem, N., Jonsson, B.H., Svenson, M. und Carlsson, U. (1992) Isomerase and chaperone activity of prolyl isomerase in the folding of carbonic anhydrase. Science. 258(5081):466-8.

Gilbert, H.F. (1998) Protein disulfide isomerase. Methods Enzymol. 290, 26-50.

Goldberger, R.F., Epstein, C.J. und Anfinsen, C.B. (1963) Acceleraion of reactivation of reduced bovine pancreatic ribonuclease by a microsomal system from rat liver. J. Biol. Chem. 238, 628-635.

Guddat, L.W., Bardwell, J.C. und Martin, J.L. (1998) Crystal structure of reduced and oxidized DsbA: investigation of domain motion and thiolate stabilization. Structure, 6, 757-767.

Hayano, T.und Kikuchi, M. (1995) Molecular cloning of the cDNA encoding a novel protein disulfide isomerase-related protein (PDIR). FEBS Lett. 372(2-3):210-4.

Hebert, D.N., Foellmer, B. und Helenius, A. (1996) Calnexin and calreticulin promote folding, delay oligomerization and suppress degradation of influenza hemagglutinin in microsomes. Embo J. 15, 2961-2968

Helenius, A., Trombetta, E.S., Hebert, D.N. und Simons, J.F. (1997) Calnexin, calreticulin and the folding of glycoproteins. Trends Cell Biol. 7, 193-200.

Hong, C.C. und Hashimoto, C. (1995) An unusual mosaic protein with a protease domain, encoded by the nudel gene, is involved in defining embryonic dorsoventral polarity in Drosophila. Cell. 82(5):785-94.

Hosoda, A., Kimata, Y., Tsuru, A. und Kohno, K. (2003) JPDI, a novel endoplasmic reticulum-resident protein containing both a BiP-interacting J-domain and thioredoxin-like motifs. J Biol Chem. 278(4):2669-76.

Hwang, C., Sinskey, A.J. und Lodish, H.F. (1992) Oxidized redox state of glutathione in the endoplasmic reticulum. Science 257, 1496-1502. 
Jeenes, D.J., Pfaller, R. und Archer, D.B. (1997) Isolation and characterisation of a novel stress-inducible PDI-family gene from Aspergillus niger. Gene 193, 151-156.

Katti, S.K., LeMaster, D.M. und Eklund, H. (1990) Crystal structure of thioredoxin from Escherichia coli at 1.68 A resolution. J. Mol. Biol. 212, 167-184.

Kassenbrock, C.K., Garcia, P.D., Walter, P., Kelly, R.B. (1988) Heavy-chain binding protein recognizes abberant polypeptides translocated in vitro. Nature. 333(6168):90-3.

Kemmink, J., Darby, N.J., Dijkstra, K., Nilges, M. und Creighton, T.E. (1997) The folding catalyst protein disulfide isomerase is constructed of active and inactive thioredoxin modules. Curr. Biol. 7, 239-245.

Klappa, P., Freedman, R.B., Langenbuch, M., Lan, M.S., Robinson, G.K. und Ruddock, L.W. (1991) The pancreas-specific protein disulphide-isomerase PDIp interacts with a hydroxyaryl group in ligands. Biochem J. 354(Pt 3):553-9.

Klappa, P., Ruddock, L.W., Darby, N.J. und Freedman, R.B. (1998) The b' domain provides the principal peptide-binding site of protein disulfide isomerase but all domains contribute to binding of misfolded proteins. EMBO J. 17(4):927-35.

Konsolaki, M. und Schüpbach, T. (1998) Windbeutel, a gene required for dorsoventral patterning in Drosophila, encodes that has homologies to vertebrate proteins of the endoplasmic reticulum. Genes Dev. 12(1):120-31.

Kosak, M. (1987) An analysis of 5'-noncoding sequences from 699 vertebrate messenger RNAs. Nucleic Acids Res. 15 (20): 8125-8148.

Kozutsumi, Y., Segal, M., Normington, K., Gething, M.J. und Sambrook, J. (1988) The presence of malfolded proteins in the endoplasmic reticulum signals the induction of glucose-regulated proteins. Nature 332, 462-464.

Laemmli, U.K. (1970) Cleavage of structural proteins during assembly of the head of bacteriophage T4. Nature 227, 680-85.

Lundström-Ljung, J., Birnbach, U., Rupp, K., Söling, H.D. and Holmgren, A. (1995) Two resident ER-proteins, CaBP1 and CaBP2, with thioredoxin domains, are substrates for thioredoxin reductase: comparison with protein disulfide isomerase. FEBS Letters 357, 305-308.

Ma, Q., Barnewitz, K., Sheldrick, G.M., Söling, H.D., Uson, I. und Ferrari, D.M. (2003) Crystal structure and functional analysis of drosophila Wind - a proteindisulfide isomerase-related protein. J. Biol. Chem. 278(45):44600-7.

Macer, D.R.J. and Koch, G.L.E. (1988) Identification of a set of calcium-binding proteins in reticuloplasm, the luminal content of the endoplasmic reticulum. J. Cell Sci. 91, 61-70. 
Missiakes, D., Georgopoulos, C. und Raina, S. (1993) Identification and characterization of the Escherichia coli gene DsbB, whose product is involved in the formation of disulfide bonds in vivo. Proc. Nat. Acad. Sci USA 90(15);7084-8.

Monnat, J., Hacker, U., Geissler, H., Rauchenberger, R., Neuhaus, E.M., Maniak, M. und Soldati, T. (1997) Dictyostelium discoideum protein disulfide isomerase, an endoplasmic reticulum resident enzyme lacking a KDEL-type retrieval signal. FEBS Lett. 418, 357-362.

Monnat, J., Neuhaus, E.M., Pop, M.S., Ferrari, D.M., Kramer, B. und Soldati, T. (2000) Identification of a novel saturable endoplasmic reticulum localization mechanism mediated by the C-terminus of a Dictyostelium protein disulfide isomerase. Mol Biol. Cell. (10):3469-84.

Mullis, K., Faloona, F., Scharf S., Saiki, R., Horn, G. und Erlich, H. (1986)

Specific enzymatic amplification of DNA in vitro: the polymerase chain reaction. Cold Spring Harbor Symposia on quantitative Biology. 51, 263-73.

Neumann-Silberberg, F.S. und Schüpbach, T. (1993) The drosophila dorsoventral patterning gene gurken produces a dorsally localized RNA and encodes a TGF alphalike protein. Cell 75(1);165-74.

Noiva, R. und Lennarz, W.J. (1992) Protein disulfide isomerase. A multifunctional protein resident in the lumen of the endoplasmic reticulum. J. Biol. Chem. 267, 35533556 .

Noiva, R., Freedman, R.B. und Lennarz, W.J. (1993) Peptide binding to protein disulfide-isomerase occurs at a site distinct from the active-sites. J. Biol. Chem. 268, 19210-19217.

Nguyen Van, P., Peter, F. und Söling, H.D. (1989) Four intracisternal calciumbinding glycoproteins from rat liver microsomes with high affinity for calcium. J. Biol. Chem. 264, 17494-17501.

Oliver, J.D., Vanderwal, F.J., Bulleid, N.J. und High, S. (1997) Interaction of the thiol-dependent reductase ERp57 with nascent glycoproteins. Science 275, 86-88.

Pihlajaniemi, T., Helaakoski, T., Tasanen, K., Myllyla, R., Huhtala, M.L., Koivu, J. und Kivirikko, K.I. (1987) Molecular cloning of the beta-subunit of human prolyl 4-hydroxylase. This subunit and protein disulfide isomerase are products of the same gene. Embo J. 6, 643-649.

Pirneskoski, A., Klappa, P., Lobell, M., Williamson, R.A., Byrne, L., Alanen, H.I., Salo, K.E., Kivirikko, K.I., Freedman, R.B. und Ruddock, L.W. (2004) Molecular characterization of the principal substrate binding site of the ubiquitous folding catalyst protein disulfide isomerase. J Biol Chem. 279(11):10374-81.

Ruddock, L.W., Freedman, R.B. und Klappa, P. (2000) Specificity in substrate binding by protein folding catalysts: tyrosine and tryptophan residues are the recognition motifs for the binding of peptides to the pancreas-specific protein disulfide isomerase PDIp. Protein Sci. (4):758-64. 
Seergev, P., Streit, A., Heller, A. und Steinmann-Zwicky, M. (2001) The Drosophila dorsoventral determinant PIPE contains 10 copies of a variable domain homologous to mammalian heparan sulfate 2-sulfotransferase. Dev Dyn. (2):122-32.

Sen, J., Goltz ,J.S., Stevens, L. und Stein, D. (1998) Spatially restricted expression of pipe in the drosophila egg chamber defines embryonic dorsal-ventral polarity. Cell. 95(4):471-81.

Sen, J., Goltz,J.S., Konsolaki, M., Schüpbach, T. und Stein, D. (2000) Windbeutel is required for function and correct subcellular localization of the Drosophila patterning protein Pipe. Development. 27(24):5541-50.

Shorrosh, B.S. und Dixon, R.A. (1992) Molecular characterization and expression of an alfalfa protein with sequence similarity to mammalian ERp72, a glucose-regulated endoplasmic reticulum protein containing active site sequences of protein disulphide isomerase. Plant J. 2, 51-58.

Tachikawa, H., Funahashi, W., Takeuchi, Y., Nakanishi, H., Nishihara, R., Katoh, S., Gao, X.D., Mizunaga, T. und Fujimoto, D. (1997) Overproduction of $\mathrm{Mpd} 2 \mathrm{p}$ suppresses the lethality of protein disulfide isomerase depletion in a CXXC sequence dependent manner. Biochemical \& Biophysical Research Communications 239, 710-714.

Towbin, H., Staehelin, T.und Gordon, J. (1992) Electrophoretic transfer of proteins from polyacrylamide gels to nitrocellulose sheets: procedure and some applications. Biotechnology. 24:145-9.

Van der Wal, F.J., Oliver, J.D. und High, S. (1998) The transient association of ERp57 with N-glycosylated protein is regulated by glucose trimming. Eur J Biochem 15;256(1):51-9.

Wada, I., Rindress, D., Cameron, P.H., Ou, W.J., Doherty, J.J., Louvard, D., Bell, A.W., Dignard, D., Thomas, D.Y. und Bergeron, J.J. (1991) SSR alpha and associated calnexin are major calcium binding proteins of the endoplasmic reticulum membrane. J. Biol. Chem. 266, 19599-19610.

Wetterau, J.R., Combs, K.A., Spinner, S.N. und Joiner, B.J. (1990) Protein disulfide isomerase is a component of the microsomal triglyceride transfer protein complex.

J Biol Chem. 265(17):9801-7.

Zacharias, D.A., Violin, J.D., Newton, A.C. und Tsien, R.Y. (2002) Partitioning of lipid-modified GFPs into membrane microdomains of live cells. Science 296, 913916. 


\section{Abkürzungsverzeichnis}

3D

$\AA$

A. bidest

APS

AS

ATP

BiP

Bp

BSA

bzw.

cDNA

$\mathrm{cm}$

C-Terminus

$\mathrm{CO}_{2}$

Dd-PDI

DMEM

DMSO

DNA

dNTPs

ds

DSS

D.V.

EDTA

EGF

EGF-R

ER

ERAD

et al.

FAD

FKS

for

FRET

$\mathrm{g}$

GD

GFP

GSH

GSSG

$\mathrm{h}$

HDEL

IgG

KEEL/ KDEL

$\mathrm{Kb}$

$\mathrm{KDa}$

$\mathrm{KV}$

$\mathrm{L}$

LB-Medium dreidimensional

Angström

bidestilliertes Wasser

Amoniumpersulfat

Aminosäure

Adenosintriphosphat

Immunglobulin heavy chain Bindeprotein

Basenpaare

Rinderserumalbumin

beziehungsweise

einzelsträngige DNA, komplementär zur Ribonukleinsäure

Zentimeter

Carboxy-Terminus eines Proteins

Kohlendioxid

Dictyostelium discoideum PDI

Dulbecco's modifiziertes Eagle-Medium

Dimethylsulfoxid

Desoxyribonukleinsäure

Desoxynukleotid-Triphosphate

doppelsträngig

Disuccinimidyl Suberat

dorsoventral

Ethylendiamintetraessigsäure

epidermaler Wachstumsfaktor

Rezeptor des epidermalen Wachstumsfaktors

Endoplasmatisches Retikulum

ER-assoziierte Degradation

et alii, lateinisch für: und andere

Flavinadenindinukleotid

fetales Kälberserum

Vorwärtsprimer

Fluoreszenz Resonanz Energie Transfer

Erdbeschleunigung

Gastrulationsdefekt

Grün fluoreszierendes Protein

reduziertes Glutathion

Glutathion

Stunde

Sequenzmotiv in Hefe (ER-Retention)

Immunglobulin G

Sequenzmotiv (Retention)

Kilobasenpaare

Kilo Dalton

Kilovolt

Liter

Luria-Bertani-Medium 


\begin{tabular}{|c|c|}
\hline $\begin{array}{l}\text { MTP } \\
\text { mRNA }\end{array}$ & $\begin{array}{l}\text { mikrosomales Triglycerid Transferprotein } \\
\text { messenger RNA }\end{array}$ \\
\hline $\mathrm{ms}$ & Millisekunden \\
\hline$\mu \mathrm{F}$ & Mikrofarad \\
\hline$\mu g$ & Mikrogramm \\
\hline$\mu 1$ & Mikroliter \\
\hline$\mu \mathrm{m}$ & Mikrometer \\
\hline$\mu \mathrm{M}$ & mikromolar \\
\hline M & molar \\
\hline $\mathrm{mA}$ & Milliamper \\
\hline MCS & multiple Klonierungsstelle \\
\hline Min & Minute \\
\hline $\mathrm{mM}$ & Millimol \\
\hline $\mathrm{mg}$ & Milligramm \\
\hline $\mathrm{ml}$ & Milliliter \\
\hline NADPH & Nicotinamid-adenin-dinucleotid Phosphat \\
\hline ng & Nanogramm \\
\hline N-Terminus & Amino-Terminus eines Proteins \\
\hline O.D. & optische Dichte \\
\hline$\Omega$ & Ohm \\
\hline PBS & Phosphat-gepufferte SAlzlösung \\
\hline PCR & Polymerasekettenreaktion \\
\hline PDI & Protein Disulfid Isomerase \\
\hline pEGFP, & Vektor: enhanced grünfluoreszierendes Protein \\
\hline PFA & Paraformaldehyd \\
\hline Pfu & Polymerase aus $P$. furiosus \\
\hline P4H & Prolyl-4-hydroxylase \\
\hline $\mathrm{pH}$ & $\mathrm{pH}-$ Wert \\
\hline pmol & pikomolar \\
\hline PNK & Polynukleotidkinase \\
\hline PPIasen & Peptidyl-prolyl-Isomerasen \\
\hline rev & Rückwärtsprimer \\
\hline RNA & Ribonukleinsäure \\
\hline rpm & Umdrehung pro Minute \\
\hline RT & Raumtemperatur \\
\hline RT-PCR & Reverse Transkriptase PCR \\
\hline SAP & shrimp alkaline phosphatase \\
\hline SDS & Natrium-Dodecylsulfat \\
\hline Sec & Sekunde \\
\hline S-S & Disulfid-Bindung \\
\hline Taq & Polymerase aus $T$. aquaticus \\
\hline TEMED & 1,2-Bis-(dimethylamino)-Ethan \\
\hline TCA & Trichloressigsäure \\
\hline TRIS & Hydroxymethyl-Aminomethan \\
\hline $\mathrm{U}$ & Unit (Einheit) \\
\hline UPR & unfolded protein response \\
\hline UV-Licht & ultraviolettes Licht \\
\hline $\mathrm{V}$ & Volt \\
\hline$(\mathrm{v} / \mathrm{v})$ & Volumen pro Volumen \\
\hline$(\mathrm{w} / \mathrm{v})$ & Gewicht pro Volumen \\
\hline WT & Wildtyp \\
\hline
\end{tabular}


Aminosäuren, geordnet nach ihrer alphabetischen Abkürzung:

\begin{tabular}{|l|l|l|}
\hline Buchstabencode i & Abkürzung & Aminosäure \\
\hline Ala & A & Alanin \\
Cys & C & Cystein \\
Asp & D & Asparaginsäure \\
Glu & E & Glutaminsäure \\
Phe & F & Phenylalanin \\
Gly & H & Glycin \\
His & H & Histidin \\
Ile & I & Isoleucin \\
Lys & K & Lysin \\
Leu & L & Leucin \\
Met & M & Methionin \\
Asn & N & Asparagin \\
Pro & P & Prolin \\
Gln & Q & Glutamin \\
Arg & R & Arginin \\
Ser & S & Serin \\
Thr & T & Threonin \\
Val & V & Valin \\
Trp & W & Tryptophan \\
Tyr & Y & Tyrosin \\
& & \\
\hline
\end{tabular}




\section{$\underline{\text { Lebenslauf }}$}

Name:

Geburtsdatum:

Staatsangehörigkeit:

Familienstand:

Schulbildung:

Schulabschluss:

Berufsausbildung:

Hochschulausbildung: $\quad$ seit 10/96

$11 / 98$

$11 / 00$

02/01-11/01

$01 / 02$

seit $02 / 02$
Kathrin Barnewitz

29. Januar 1974

deutsch

ledig

Einschulung in die Adolf-Reichwein-Schule, Göttingen

08/86-06/90 Besuch des Gymnasiums Liebigstrasse in Holzminden

08/90-05/95 Besuch des Otto-Hahn-Gymnasiums in Göttingen

Abitur

08/93-06/96 Ausbildung zur Biologielaborantin im Tierärztlichen Institut der Uni Göttingen

immatrikuliert für den Diplomstudiengang Biologie an der Georg-August-Universität zu Göttingen

Diplomvorprüfung

Diplomhauptprüfung

Diplomarbeit in der Abteilung Toxikologie des Universitätsklinikums Göttingen zum Thema „Regulation der Uridindiphosphat-Glucuronosyltransferase UGT2B1 mRNA-Expression in Hepatozyten der Ratte“ beschäftigt in der Abteilung Toxikologie zur Weiterführung des Projekts

Wissenschaftliche Mitarbeiterin im Max-PlanckInstitut $\mathrm{f}$. Biophysikalische Chemie in Göttingen 